\title{
Principles and potential of the anaerobic digestion of waste-activated sludge
}

\author{
Lise Appels ${ }^{\mathrm{a}}$, Jan Baeyens ${ }^{\mathrm{c}}$, Jan Degrève ${ }^{\mathrm{a}}$, Raf Dewil ${ }^{\mathrm{a}, \mathrm{b}, *}$ \\ a Department of Chemical Engineering, Katholieke Universiteit Leuven, W. De Croylaan 46, B-3001 Heverlee, Belgium \\ b Department of Chemical Engineering, Associated Faculty of Technology and Biosciences, Campus De Nayer, Katholieke Universiteit Leuven, Jan De Nayerlaan 5, \\ B-2860 Sint-Katelijne-Waver, Belgium \\ ${ }^{\mathrm{c}}$ Department of Chemical Engineering, University of Birmingham, Edgbaston, Birmingham B15 2TT, UK
}

\section{A R T I C L E I N F O}

\section{Article history:}

Received 4 February 2008

Accepted 12 June 2008

Available online 8 August 2008

\section{Keywords:}

Anaerobic digestion

Modelling

Biogas

Waste-activated sludge

\begin{abstract}
A B S T R A C T
When treating municipal wastewater, the disposal of sludge is a problem of growing importance, representing up to $50 \%$ of the current operating costs of a wastewater treatment plant. Although different disposal routes are possible, anaerobic digestion plays an important role for its abilities to further transform organic matter into biogas (60-70 vol\% of methane, $\mathrm{CH}_{4}$ ), as thereby it also reduces the amount of final sludge solids for disposal whilst destroying most of the pathogens present in the sludge and limiting odour problems associated with residual putrescible matter. Anaerobic digestion thus optimises WWTP costs, its environmental footprint and is considered a major and essential part of a modern WWTP. The potential of using the biogas as energy source has long been widely recognised and current techniques are being developed to upgrade quality and to enhance energy use. The present paper extensively reviews the principles of anaerobic digestion, the process parameters and their interaction, the design methods, the biogas utilisation, the possible problems and potential pro-active cures, and the recent developments to reduce the impact of the problems. After having reviewed the basic principles and techniques of the anaerobic digestion process, modelling concepts will be assessed to delineate the dominant parameters. Hydrolysis is recognised as rate-limiting step in the complex digestion process. The microbiology of anaerobic digestion is complex and delicate, involving several bacterial groups, each of them having their own optimum working conditions. As will be shown, these groups are sensitive to and possibly inhibited by several process parameters such as $\mathrm{pH}$, alkalinity, concentration of free ammonia, hydrogen, sodium, potassium, heavy metals, volatile fatty acids and others. To accelerate the digestion and enhance the production of biogas, various pre-treatments can be used to improve the rate-limiting hydrolysis. These treatments include mechanical, thermal, chemical and biological interventions to the feedstock. All pre-treatments result in a lysis or disintegration of sludge cells, thus releasing and solubilising intracellular material into the water phase and transforming refractory organic material into biodegradable species. Possible techniques to upgrade the biogas formed by removing $\mathrm{CO}_{2}, \mathrm{H}_{2} \mathrm{~S}$ and excess moisture will be summarised. Special attention will be paid to the problems associated with siloxanes (SX) possibly present in the sludge and biogas, together with the techniques to either reduce their concentration in sludge by preventive actions such as peroxidation, or eliminate the SX from the biogas by adsorption or other techniques. The reader will finally be guided to extensive publications concerning the operation, control, maintenance and troubleshooting of anaerobic digestion plants.
\end{abstract}

(c) 2008 Elsevier Ltd. All rights reserved.

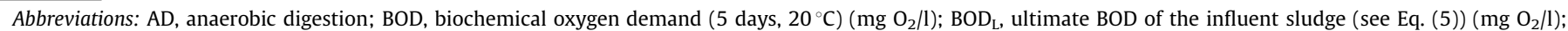

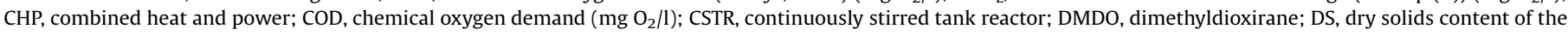

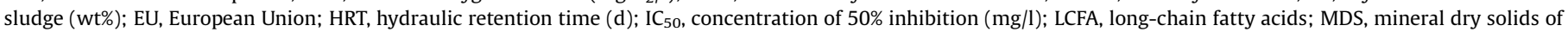
the sludge (wt\%); ODS, organic dry solids of the sludge (wt\%); ORP, oxidation reduction potential (mV); pe, population equivalent; POMS, peroxymonosulphate;

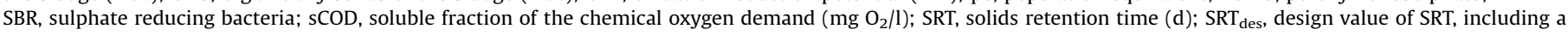
safety margin (d); SX, siloxanes; VFA, volatile fatty acids; VSS, volatile suspended solids; WAS, waste-activated sludge; WWTP, wastewater treatment plant.

* Corresponding author at: Department of Chemical Engineering, Associated Faculty of Technology and Biosciences, Campus De Nayer, Katholieke Universiteit Leuven, Jan De Nayerlaan 5, B-2860 Sint-Katelijne-Waver, Belgium. Tel.: +32 15316944 ; fax: +32 15317453.

E-mail address: raf.dewil@skynet.be (R. Dewil).
} 


\section{Contents}

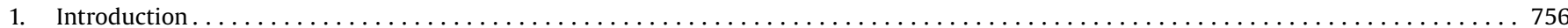

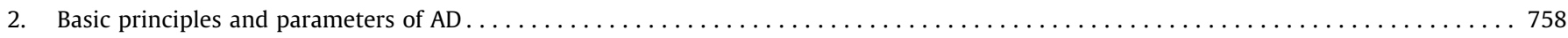

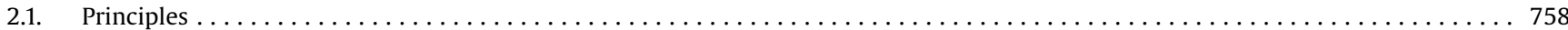

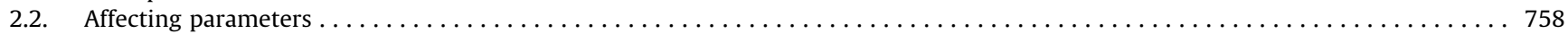

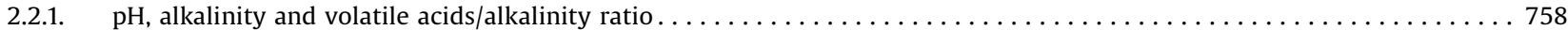

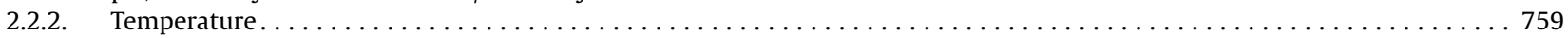

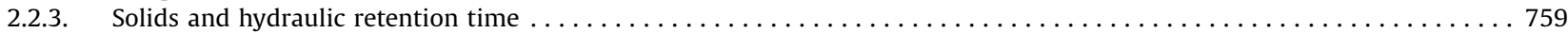

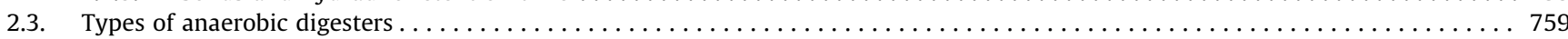

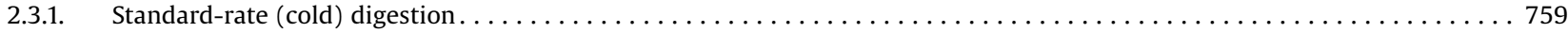

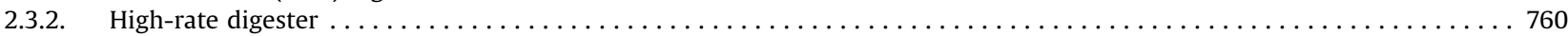

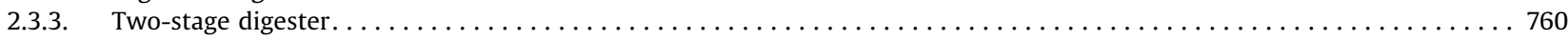

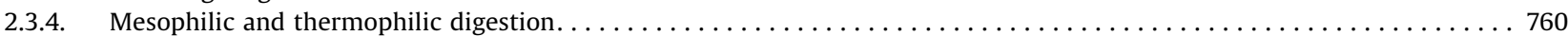

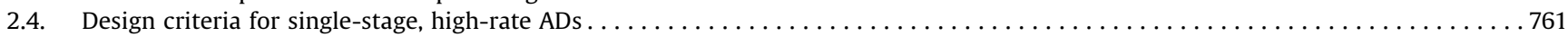

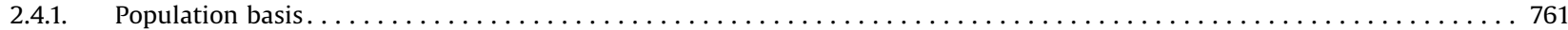

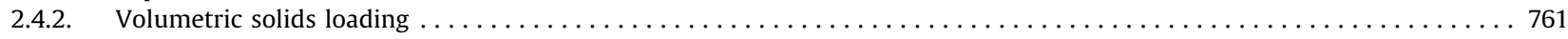

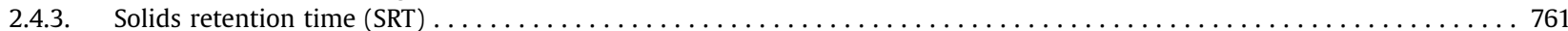

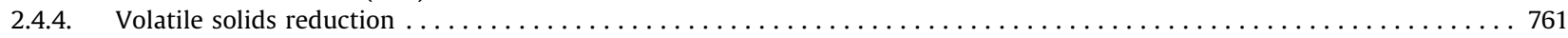

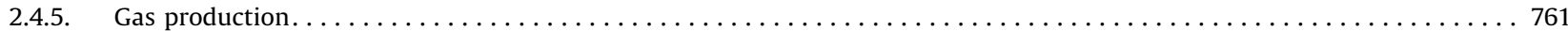

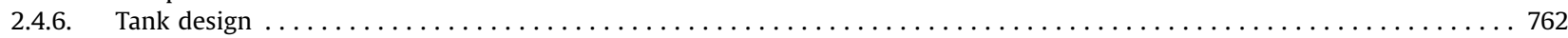

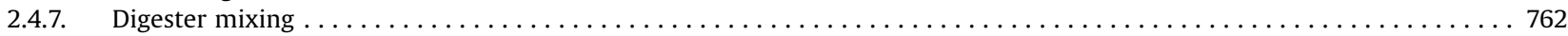

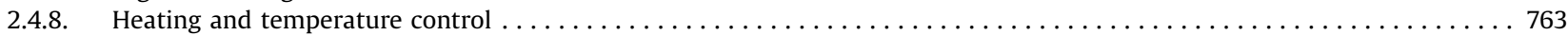

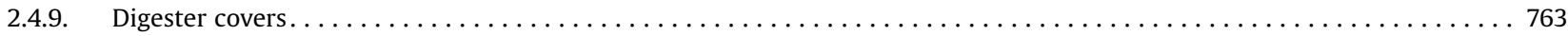

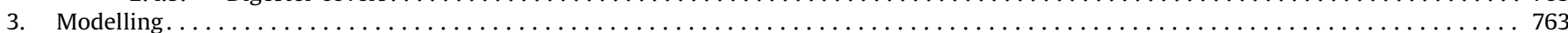

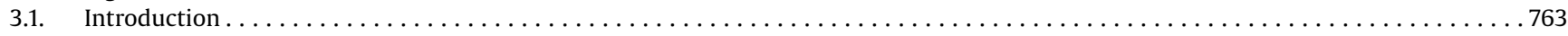

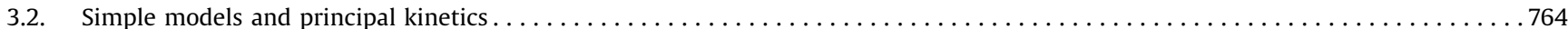

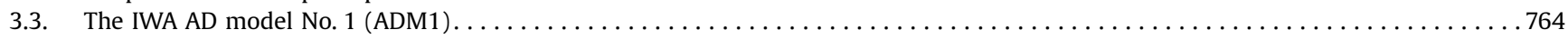

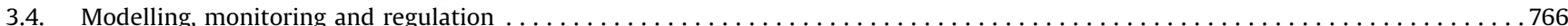

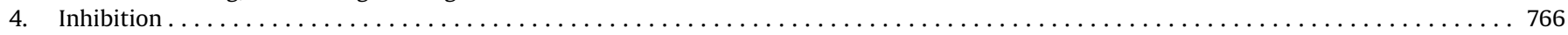

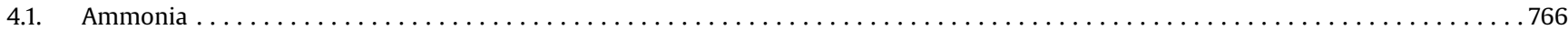

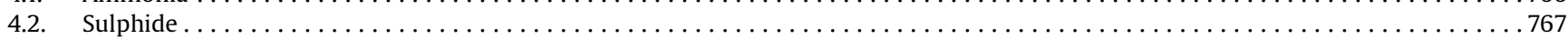

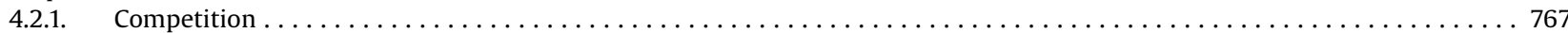

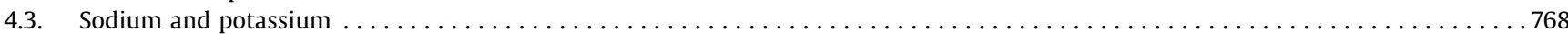

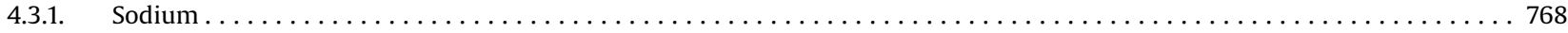

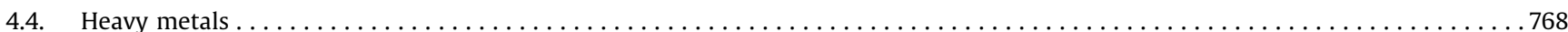

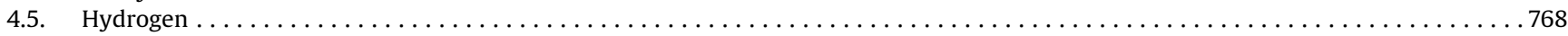

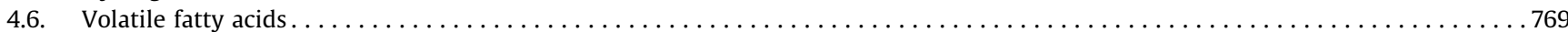

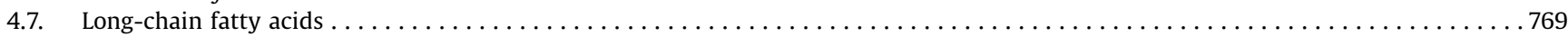

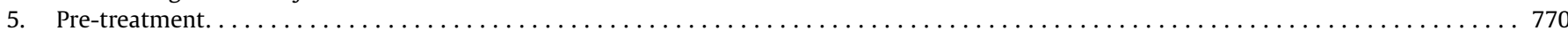

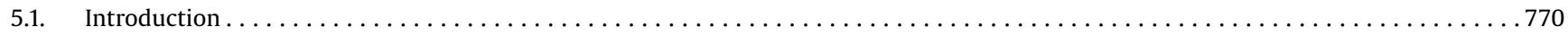

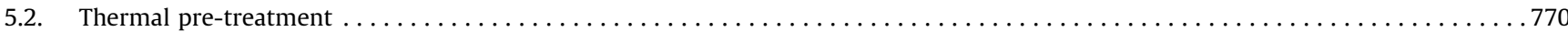

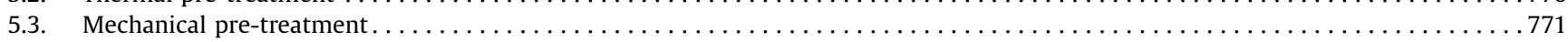

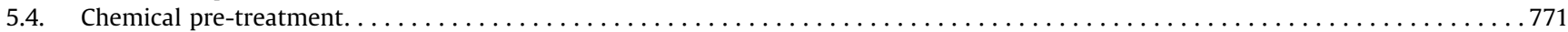

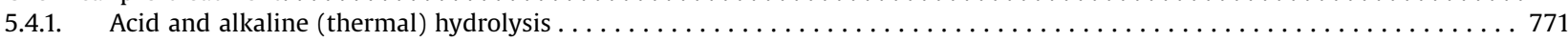

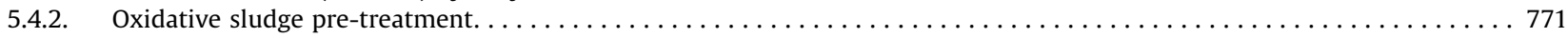

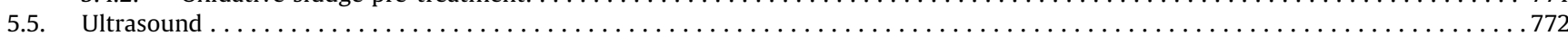

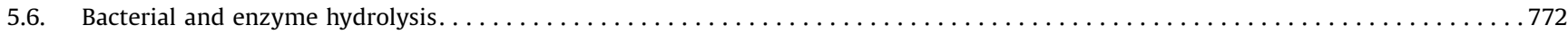

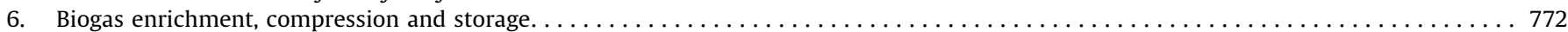

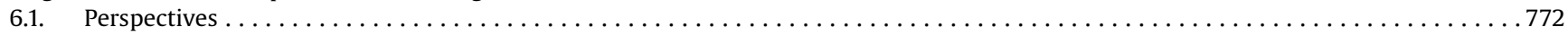

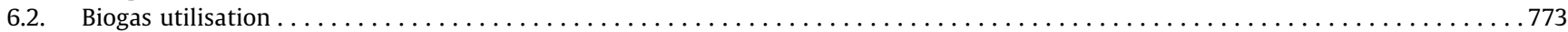

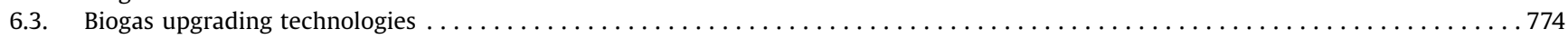

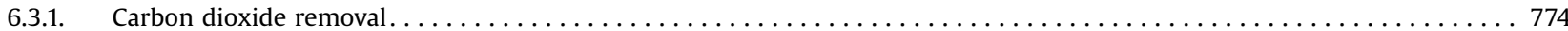

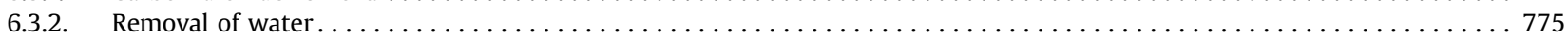

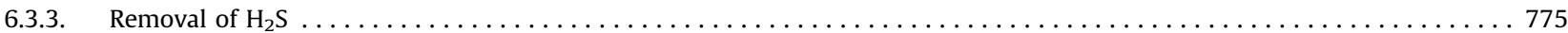

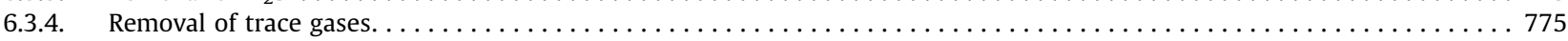

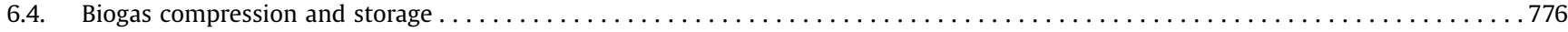

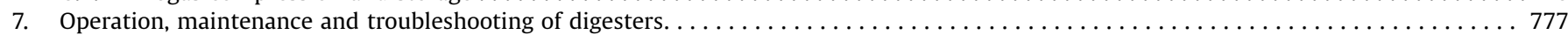

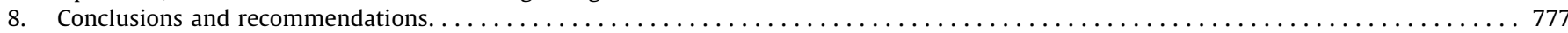

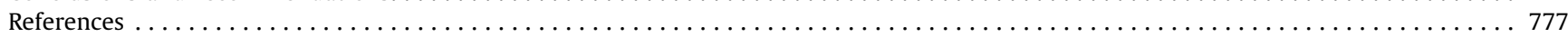

\section{Introduction}

When treating municipal wastewater, the disposal of sludge is a problem of growing importance, representing up to $50 \%$ of the current operating costs of a wastewater treatment plant (WWTP) [1]. Municipal WWTPs generate sludge as a by-product of the physical, chemical and biological processes used during treatment. Current daily amounts, expressed as dry solids (DS) range from 60 to $90 \mathrm{~g}$ DS per population equivalent (p.e.), i.e. nearly 10 million tons of dry sludge per year for the EU.

This sludge must undergo some treatment in order to reduce its associated volumes, to improve its character and to reduce the associated health problems and hindrance. This treatment will hence (i) firstly reduce the water content of the raw sludge, (ii) transform the highly putrescible organic matter into a relatively stable or inert organic and inorganic residue, and (iii) finally 
Table 1

Different sludge disposal routes

\begin{tabular}{rll}
\hline Route & Outlets & Required operations \\
\hline 1 & Agriculture (land application) & T, R \\
2 & Agriculture & T, MD, R \\
3 & Agriculture & T, AD, R \\
4 & Agriculture & T, AD, MD, R \\
5 & Landfill & T, MD, R \\
6 & Landfill & T, AD, MD, R \\
7 & Solid fuel & T, MD, ID, R \\
8 & Solid fuel & T, AD, MD,ID \\
9 & Ash & T, MD, ID, I \\
10 & Ash & T, AD, MD, ID, I \\
\hline
\end{tabular}

T: thickening to 5-6 wt\% DS; AD: anaerobic digestion to produce biogas (up to $50 \%$ conversion of ODS); R: road transport; MD: mechanical dewatering to 25-35 wt\% DS; ID: indirect drying to $85-95 \mathrm{wt} \% \mathrm{DS}$; I: incineration (autonomous in mostly fluidised bed, or co-combustion with solid fuels in power plants, cement kilns, etc.))

condition the residue to meet disposal acceptance regulation. Since land application is difficult due to stringent regulations concerning the tolerated composition [2-4], (co-)incineration is gaining increasing interest where permits can be obtained [5].

The water purification part of a WWTP commonly comprises a pre-treatment to remove about $50-60 \%$ of the suspended solids and $30-40 \%$ of the BOD [6,7]. The settled primary sludge contains mainly water (between 97\% and 99\%) and separates mostly organic matter that is highly putrescible.

The pre-treatment is followed by a biological step, where aerobic micro-organisms remove the remaining (or nearly total) BOD and suspended solids. Nitrogen $(\mathrm{N})$ and phosphorus $(\mathrm{P})$ are commonly removed simultaneously, although $\mathrm{N}$ is more usually and easily targeted first. A secondary clarifier produces the dischargeable effluent as overflow and a bottom sludge (98-99\% water), partly recycled to the biology to maintain the concentration of the micro-organisms at the required level, and partly evacuated to the sludge treatment units of the WWTP. If a pretreatment is present, primary and secondary sludge are generally combined and thickened to undergo further treatment.

This further treatment can be a combination of various steps, as reviewed in Table 1. Anaerobic digestion (AD) is an important step in most of the treatment routes.

All routes start with raw sludge (primary and secondary) produced at $1-2 \mathrm{wt} \% \mathrm{DS}$. The mineral part of the DS (MDS) is between $30 \mathrm{wt} \%$ and $45 \mathrm{wt} \%$.

A first step is its thickening by gravity, flotation or belt filtration. In doing so, the amount of sludge can be reduced to as little as a third of its initial volume. The separated water is recycled to the influent of the WWTP. Once this has been accomplished, the sludge is subject to some form of biochemical stabilisation, with $\mathrm{AD}$ playing an important role for its abilities to further transform organic matter into biogas (60-70 vol\% of methane, $\mathrm{CH}_{4}$ ), thereby also reducing the amount of final sludge solids for disposal is also reduced, destroying most of the pathogens present in the sludge, and limiting possible odour problems associated with residual putrescible matter.

For these reasons, anaerobic sludge digestion optimises WWTP costs and is considered a major and essential part of a modern WWTP. The potential of using the biogas as energy source is widely recognised. Biogas is currently produced mostly by digestion of sewage treatment sludge, with minor contributions from fermentation or gasification of solid waste or of lignocellulosic material (processes currently being further developed). It is considered an important future contributor to the energy supply of Europe, although upgrading is needed.
The annual potential of biogas production in Europe is estimated in excess of 200 billions $\mathrm{m}^{3}$.

$\mathrm{AD}$ of sludge uses airtight tanks. Essentially all organic material can be digested, except for stable woody materials since the anaerobic micro-organisms are unable to degrade lignin. The biogas which is formed has a high calorific value and is considered as a renewable energy source. Clearly, it is beneficial to produce as much biogas as possible. Despite these advantages of $\mathrm{AD}$, some limitations are inevitable, e.g. (i) only a partial decomposition of the organic fraction, (ii) the rather slow reaction rate and associated large volumes and high costs of the digesters, (iii) the vulnerability of the process to various inhibitors, (iv) the rather poor supernatant quality produced, $(\mathrm{v})$ the presence of other biogas constituents such as carbon dioxide $\left(\mathrm{CO}_{2}\right)$, hydrogen sulphide $\left(\mathrm{H}_{2} \mathrm{~S}\right)$ and excess moisture, (vi) the possible presence of volatile siloxanes in the biogas that can cause serious damage in the energy users (generator, boiler) due to the formation of microcrystalline silica, and (vii) the increased concentration of heavy metals and various industrial "organics" in the residual sludge due to the significant reduction of the organic fraction during digestion, leaving the mineral and non-degradable fraction untouched.

A process flowchart of the sludge-processing steps is shown in Fig. 1.

The present paper will attempt to extensively review the principles of $\mathrm{AD}$ of sewage sludge, the process parameters and their interaction, the design methods, the biogas utilisation, the possible problems and potential pro-active measures, and the recent developments to reduce the impact of the difficulties described above.

Section 2 will review the basic principles and parameters of the $\mathrm{AD}$ process, including the process description, the types of anaerobic digesters (standard rate, high-rate, two-stage, mesophilic, thermophilic), the current empirical design methods, the common operating parameters and the resultant biogas yields.

Modelling and monitoring the AD process are dealt with in Section 3: models can tentatively be divided into either simple steady-state models or complex dynamic simulation models. When required system performance criteria are defined, steadystate models predict the operating parameters and lead to a system design with reasonable accuracy. These approximate design and operating parameters can then be used as input to the more complex simulation models to investigate the dynamic behaviour of the system and fine-tune the design and operating parameters in real-time.

Having studied the dominant parameters, Section 4 will focus on the operational vulnerability of digestion. The microbiology of the $\mathrm{AD}$ is complex and delicate, involving several bacterial groups, each of them having their own optimum working conditions. They are sensitive to several process parameters such as $\mathrm{pH}$, alkalinity, concentration of free ammonia, hydrogen, volatile fatty acids (VFA), etc. These parameters can be inhibiting factors to some or all bacterial groups, and modern approaches include these inhibiting effects in modelling, in investigating the behaviour of the system and in controlling the process.

Section 5 will describe novel methods to accelerate the digestion through enhancing the rate-limiting hydrolysis. Various pre-treatments have recently been studied and include mechanical, thermal, chemical and biological interventions. All pre-treatments result in a lysis or disintegration of sludge cells, thus releasing and solubilising intracellular material into the water phase and transforming refractory organic material into biodegradable species, therefore making more material readily available for microorganisms. It will be shown that these pre-treatments enhance the biogas generation. Since the degradation rate is moreover accelerated, the dimensions of the digesters can be reduced for a given load, thus reducing the capital requirements. 


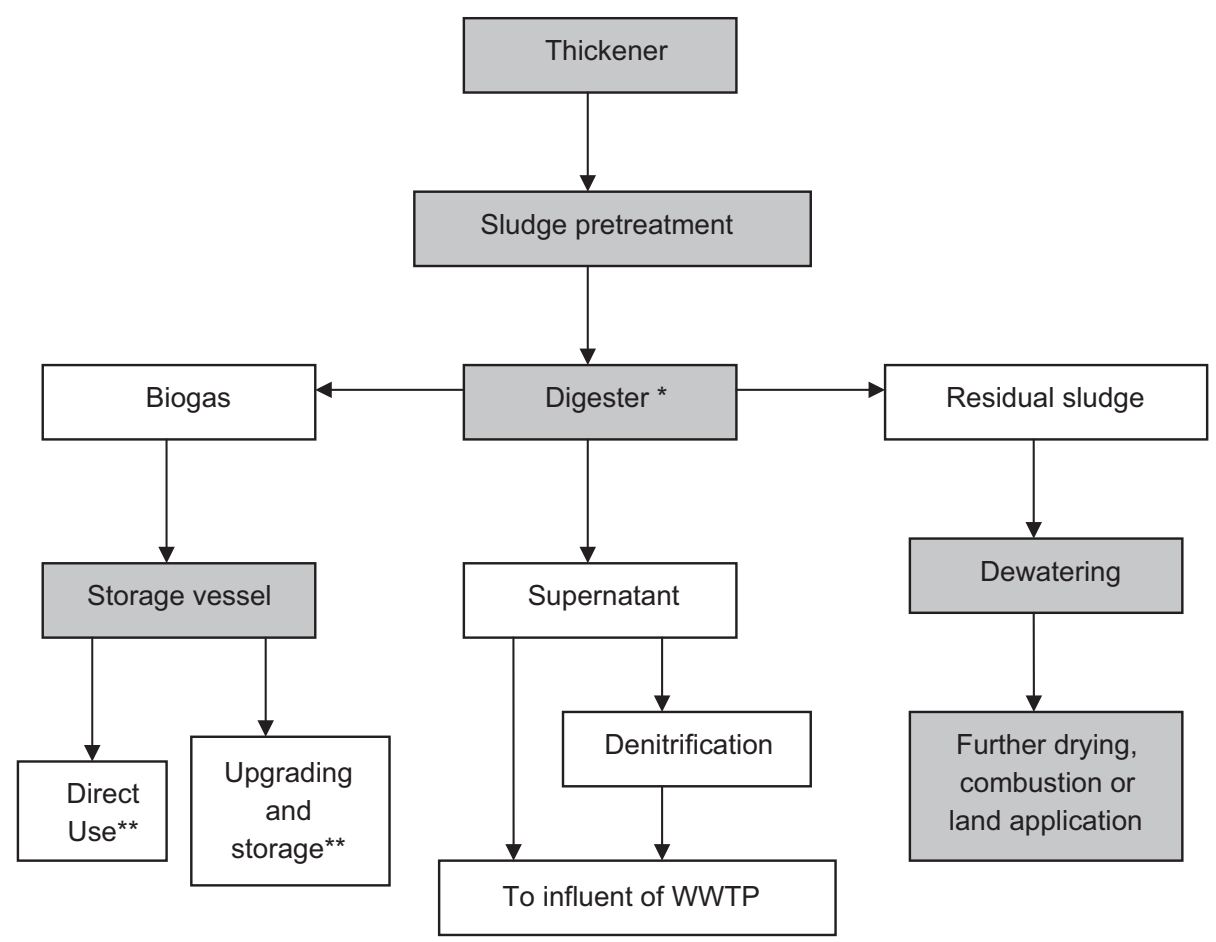

Fig. 1. Process flowchart of the sludge processing steps: ${ }^{*}$ see Fig. $4,{ }^{* *}$ see Fig. 8.

Section 6 will focus on the possible techniques to upgrade the biogas formed by removing $\mathrm{CO}_{2}, \mathrm{H}_{2} \mathrm{~S}$ and excess moisture. A special attention will be paid to the problems associated with siloxanes (SX), including their origin and behaviour in sludge, and the techniques to either reduce their concentration in sludge by preventive actions such as peroxidation, or to eliminate the SX from the biogas by adsorption or other techniques.

Section 7 will guide the reader to extensive publications concerning the operation, control, maintenance and troubleshooting of $\mathrm{AD}$ plants.

\section{Basic principles and parameters of $A D$}

\subsection{Principles}

The AD of organic material basically follows; hydrolysis, acidogenesis, acetogenesis and methanogenesis as shown in Fig. 2. The biological aspects of $A D$ are dealt with in specialised literature [8-11].

$\mathrm{AD}$ is a complex process which requires strict anaerobic conditions (oxidation reduction potential (ORP) $<-200 \mathrm{mV}$ ) to proceed, and depends on the coordinated activity of a complex microbial association to transform organic material into mostly $\mathrm{CO}_{2}$ and methane $\left(\mathrm{CH}_{4}\right)$. Despite the successive steps, hydrolysis is generally considered as rate limiting [7,12-16].

The hydrolysis step degrades both insoluble organic material and high molecular weight compounds such as lipids, polysaccharides, proteins and nucleic acids, into soluble organic substances (e.g. amino acids and fatty acids). The components formed during hydrolysis are further split during acidogenesis, the second step. VFA are produced by acidogenic (or fermentative) bacteria along with ammonia $\left(\mathrm{NH}_{3}\right), \mathrm{CO}_{2}, \mathrm{H}_{2} \mathrm{~S}$ and other by-products.

The third stage in $\mathrm{AD}$ is acetogenesis, where the higher organic acids and alcohols produced by acidogenesis are further digested by acetogens to produce mainly acetic acid as well as $\mathrm{CO}_{2}$ and $\mathrm{H}_{2}$. This conversion is controlled to a large extent by the partial pressure of $\mathrm{H}_{2}$ in the mixture.

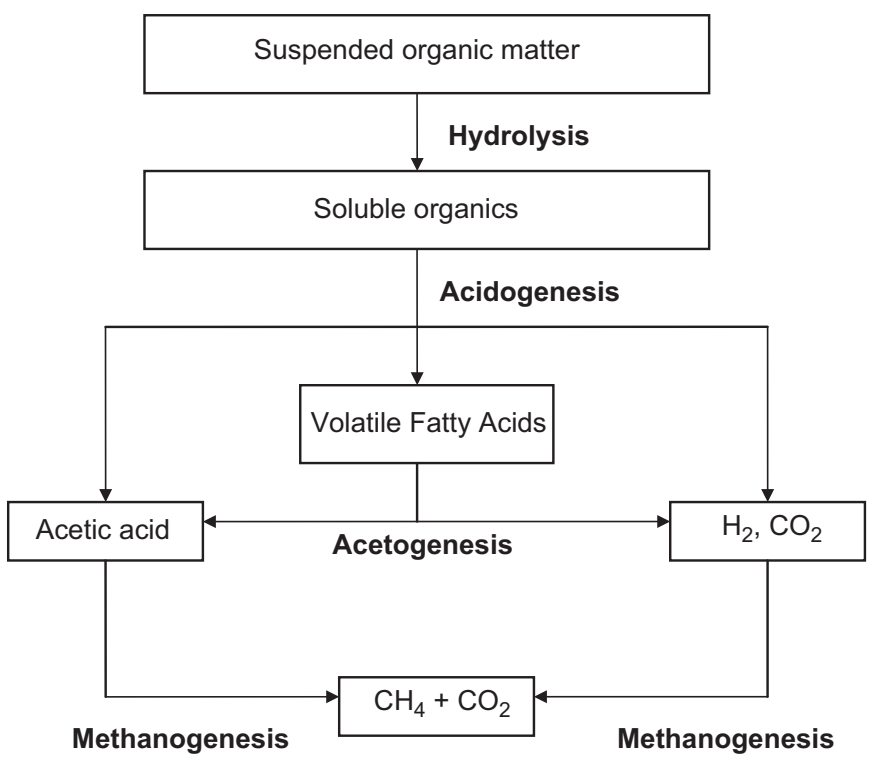

Fig. 2. Subsequent steps in the anaerobic digestion process.

The final stage of methanogenesis produces methane by two groups of methanogenic bacteria: the first group splits acetate into methane and carbon dioxide and the second group uses hydrogen as electron donor and carbon dioxide as acceptor to produce methane.

\subsection{Affecting parameters}

Within the anaerobic environment, various important parameters affect the rates of the different steps of the digestion process, i.e. $\mathrm{pH}$ and alkalinity, temperature, and retention times.

\subsection{1. $\mathrm{pH}$, alkalinity and volatile acids/alkalinity ratio}

Each group of micro-organisms has a different optimum $\mathrm{pH}$ range. Methanogenic bacteria are extremely sensitive to $\mathrm{pH}$ with 
an optimum between 6.5 and 7.2 [17,18]. The fermentative microorganisms are somewhat less sensitive and can function in a wider range of $\mathrm{pH}$ between 4.0 and 8.5 [19]: at a low $\mathrm{pH}$ the main products are acetic and butyric acid, while at a $\mathrm{pH}$ of 8.0 mainly acetic and propionic acid are produced [17].

The VFAs produced during $\mathrm{AD}$ tend to reduce the $\mathrm{pH}$. This reduction is normally countered by the activity of the methanogenic bacteria, which also produce alkalinity in the form of carbon dioxide, ammonia and bicarbonate $[18,20]$. The system $\mathrm{pH}$ is controlled by the $\mathrm{CO}_{2}$ concentration in the gas phase and the $\mathrm{HCO}_{3}$-alkalinity of the liquid phase. If the $\mathrm{CO}_{2}$ concentration in the gas phase remains constant, the possible addition of $\mathrm{HCO}_{3}$-alkalinity can increase the digester $\mathrm{pH}$ [18]. A buffering capacity of 70 meq $\mathrm{CaCO}_{3} / \mathrm{l}$ or a molar ratio of at least $1.4: 1$ of bicarbonate/VFA should be maintained for a stable and wellbuffered digestion process although it has been shown that especially the stability of the ratio is of prime importance, and not so much its level [20].

\subsubsection{Temperature}

The temperature has an important effect on the physicochemical properties of the components found in the digestion substrate. It also influences the growth rate and metabolism of micro-organisms and hence the population dynamics in the anaerobic reactor. Acetotrophic methanogens are one of the most sensitive groups to increasing temperatures. The degradation of propionate and butyrate is also sensitive to temperatures above $70^{\circ} \mathrm{C}$. The temperature has moreover a significant effect on the partial pressure of $\mathrm{H}_{2}$ in digesters, hence influencing the kinetics of the syntrophic metabolism. Thermodynamics show that endergonic reactions (under standard conditions), for instance the breakdown of propionate into acetate, $\mathrm{CO}_{2}, \mathrm{H}_{2}$, would become energetically more favourable at higher temperature, while reactions which are exergonic (e.g. hydrogenotrophic methanogenesis) are less favoured at higher temperatures [21].

An increasing temperature has several benefits [17,21] including an increasing solubility of the organic compounds, enhanced biological and chemical reaction rates, and an increasing death rate of pathogens (thermophilic conditions).

However, the application of high temperatures (thermophilic) has counteracting effects: there will be an increase of the fraction of free ammonia, which plays an inhibiting role for the microorganisms; but the increasing $\mathrm{p} K_{\mathrm{a}}$ of the VFA will make the process more susceptible to inhibition [17]. Control is thus a very sensitive issue for thermophilic as compared to mesophilic digestion.

It is important to maintain a stable operating temperature in the digester, since sharp and/or frequent fluctuations in temperature affect the bacteria, especially the methanogens. Process failure can occur at temperature changes in excess of $1^{\circ} \mathrm{C} /$ day; and changes in temperature of more than $0.6^{\circ} \mathrm{C} /$ day should be avoided [18].

\subsubsection{Solids and hydraulic retention time}

The solids retention time (SRT) is the average time the solids spend in the digester, whereas the hydraulic retention time (HRT) is the average time the liquid sludge is held in the digester. The subsequent steps of the digestion process are directly related to the SRT. A decrease in the SRT decreases the extent of the reactions and vice versa. Each time sludge is withdrawn, a fraction of the bacterial population is removed thus implying that the cell growth must at least compensate the cell removal to ensure steady state and avoid process failure $[18,20]$.

The influence of the retention time on the breakdown efficiency is mostly studied on laboratory scale [20] and the obtained relationship between gas production and retention time

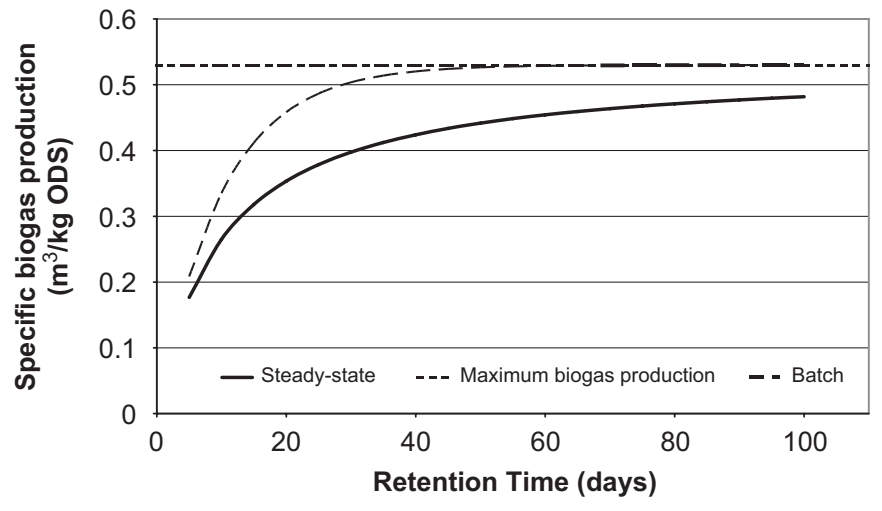

Fig. 3. Biogas production vs. SRT.

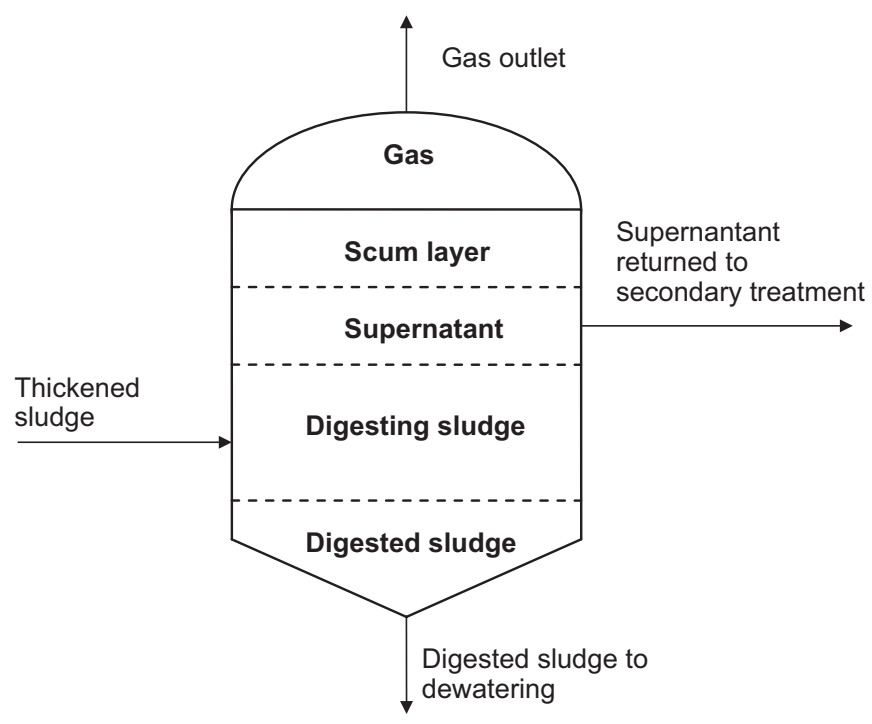

Fig. 4. Standard-rate digester.

in a (semi-)CSTR indicates that (i) retention times shorter than 5 days are insufficient for a stable digestion: VFA concentrations are increasing due to a washout of methanogenic bacteria, (ii) VFA concentrations are still relatively high for SRT of 5-8 days: there is an incomplete breakdown of compounds, especially of the lipids, (iii) stable digestion is obtained after 8-10 days: low VFA concentrations, the breakdown of lipids starts, and (iv) the breakdown curve stabilises at SRT $>10$ days; all sludge compounds are significantly reduced. The SRT is a fundamental design and operating parameter for all anaerobic processes.

A schematic representation of SRT vs. degree of digestion is added in Fig. 3.

\subsection{Types of anaerobic digesters}

\subsubsection{Standard-rate (cold) digestion}

This type of $\mathrm{AD}$ is the simplest type using a long digestion period of 30-60 days. A schematic representation of this type of digester is added in Fig. 4. The sludge content is usually neither heated nor mixed. Although the biogas generated provides some form of mixing, stratification occurs in four zones: (i) a scumlayer, (ii) a liquid layer (or supernatant), (iii) a layer of digesting solids, and (iv) a layer of digested solids. The supernatant is withdrawn and recycled to the wastewater treatment plant. The accumulated digested solids at the bottom of the digester are periodically 
extracted. Nowadays standard rate units are seldomly built, except for smaller WWTPs $[6,7,18]$.

\subsubsection{High-rate digester}

This digester is a major improvement of the standard-rate digestion. The sludge is heated and completely mixed, the raw sludge is thickened and the feeding is uniform. All these elements combined create a uniform environment as a result of which the tank volume can be reduced and the process stability and efficiency are improved [18]. The sludge is mixed by gas recirculation, pumping or draft-tube mixers; it is mostly heated by external heat exchangers because of their flexibility and ease of maintenance. Other ways of heating include internal heat exchangers and steam injection [6,18]. Uniform feeding is very important, and the sludge should be fed continuously or at regular

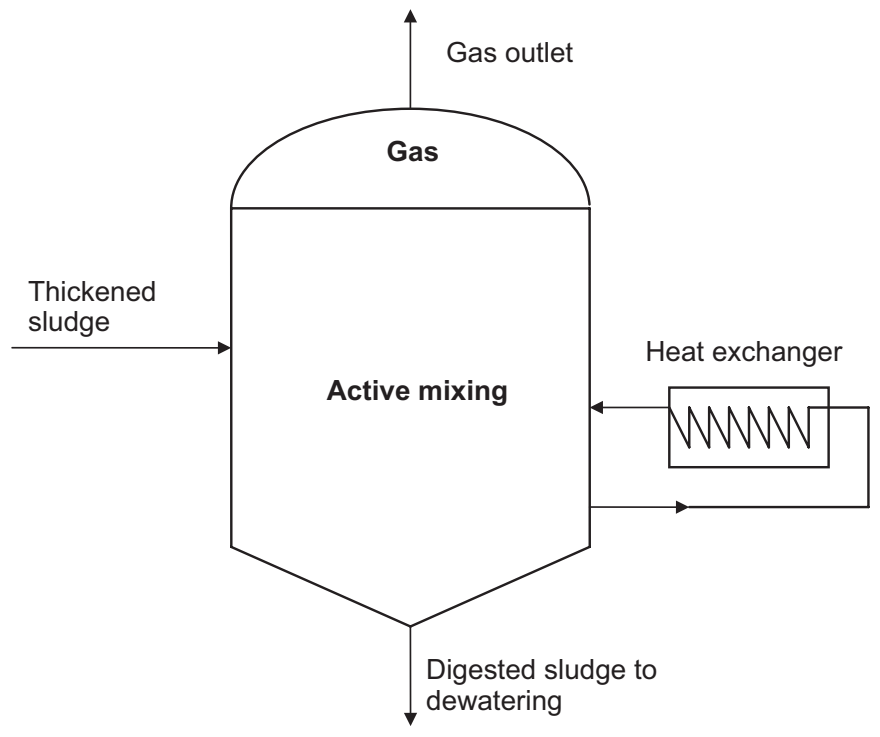

Fig. 5. High-rate digester. intervals to help maintain steady-state conditions in the digester and reduce shock loadings, especially important for the sensitive methanogenic bacteria $[6,7,18]$. This steady draw and fill mode is also important to improve pathogen kill. This type of digester is shown in Fig. 5.

\subsubsection{Two-stage digester}

In two-stage digestion, a high-rate digester is coupled with a second tank, sometimes called a secondary digester (see Fig. 6) although merely used to store the digested solids and decant the supernatant: it is neither heated nor mixed. The tanks may have fixed roofs or floating covers. If the secondary tank is of the floating cover type, it can also be used to store digester gas. Very little solids reduction and gas production take place in the second tank. Sometimes, primary and secondary tanks are of equal design, each with heating and mixing capacity to serve as a standby digester. The supernatant withdrawn from the second tank may contain high concentrations of suspended solids and these poor settling phenomena are commonly associated with an incomplete digestion in the primary digester, leading to small gas bubbles present in the suspension within the second tank. Moreover, due to the mixing and natural breakdown of the solids, fine particles or flocs are produced which do not settle easily $[6,7,18]$.

Although this type of twin digestion was very popular in the past, it is rarely used in newer plants.

\subsubsection{Mesophilic and thermophilic digestion}

Most high-rate digesters are operated in the mesophilic range, with a temperature between 30 and $38^{\circ} \mathrm{C}$ [7]. AD can also take place at higher temperatures, in the thermophilic region, where digestion occurs at temperatures between 50 and $57{ }^{\circ} \mathrm{C}$ suitable for thermophilic bacteria. Thermophilic digestion is faster than mesophilic digestion since the biochemical reaction rates increase with increasing temperature. Other advantages are an increased solids reduction, improved dewatering, and increased destruction of pathogenic organisms. The use of thermophilic temperatures

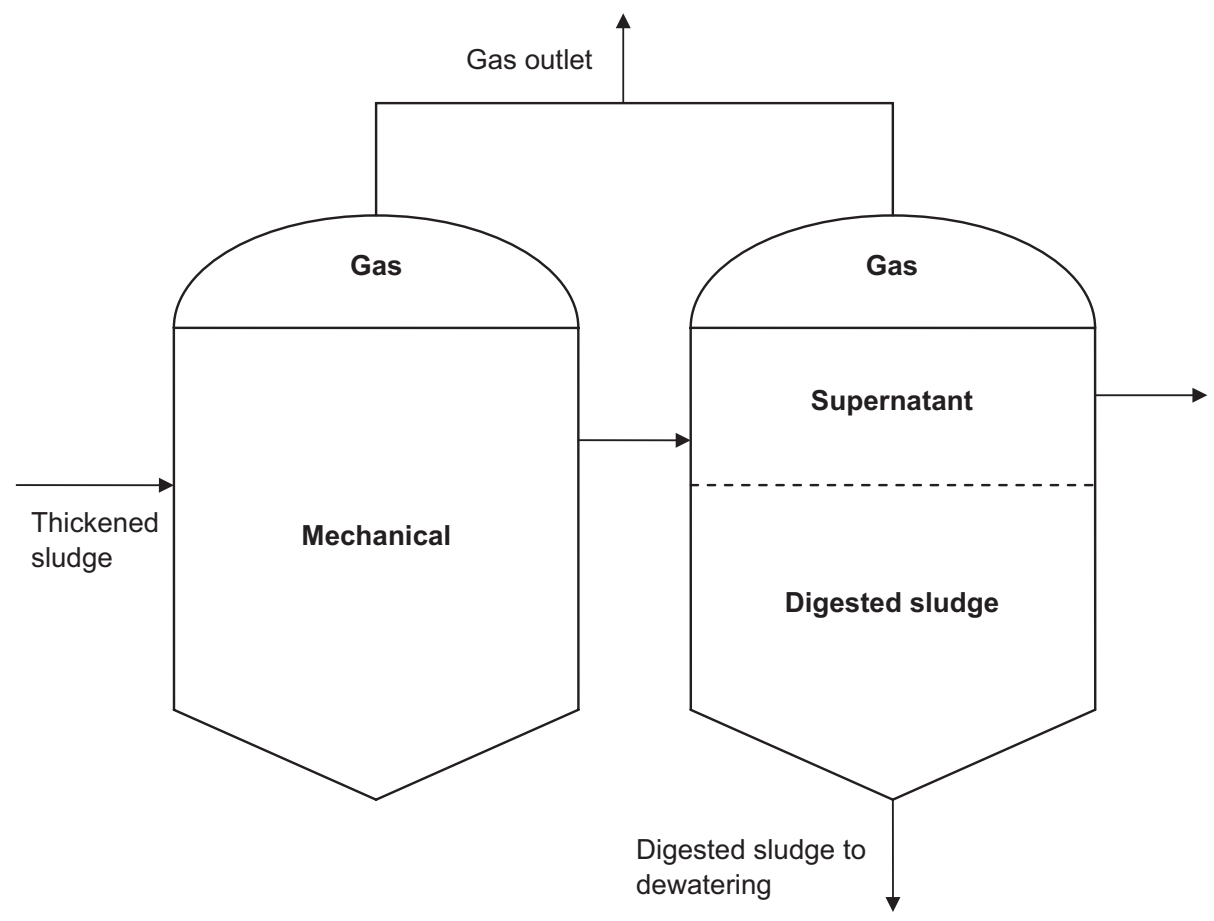

Fig. 6. Two-stage digester. 
Table 2

Typical design criteria for mesophilic digestion $[6,7,18]$

\begin{tabular}{|c|c|c|c|}
\hline \multirow[t]{2}{*}{ Parameter } & \multirow[t]{2}{*}{ Units } & \multicolumn{2}{|l|}{ Value } \\
\hline & & $\begin{array}{l}\text { Standard } \\
\text { rate }\end{array}$ & High rate \\
\hline \multicolumn{4}{|l|}{ Volume criteria } \\
\hline Primary sludge & $\mathrm{m}^{3} /$ capita & $0.06-0.08$ & $0.03-0.06$ \\
\hline $\begin{array}{l}\text { Primary sludge+trickling filter } \\
\text { humus sludge }\end{array}$ & $\mathrm{m}^{3} /$ capita & $0.06-0.14$ & $0.07-0.09$ \\
\hline Primary sludge+activated sludge & $\mathrm{m}^{3} /$ capita & $0.06-0.08$ & $0.07-0.11$ \\
\hline Solids loading rate & $\mathrm{kgVSS} / \mathrm{m}^{3} \mathrm{~d}$ & $0.64-1.60$ & $1.6-4.8$ \\
\hline Solids retention time & d & $30-60$ & $10-20$ \\
\hline \multicolumn{4}{|l|}{ Sludge concentration } \\
\hline $\begin{array}{l}\text { Primary sludge+biological sludge } \\
\text { feed }\end{array}$ & $\%$ & $2-4$ & $4-7$ \\
\hline Digested sludge draw-off & $\%$ & $4-6$ & $4-7$ \\
\hline
\end{tabular}

however has a higher energy requirement, a lower quality supernatant with large quantities of dissolved solids, a higher odour potential and much poorer process stability requiring great care. The latter is due to the fact that thermophilic bacteria are far more sensitive to temperature fluctuations than their mesophilic colleagues $[6,7,18]$.

\subsection{Design criteria for single-stage, high-rate ADs}

A number of guideline parameters for the design and operation of single-stage high-rate ADs have been discussed in the literature $[6,7,18,22]$, and are summarised hereafter. They can be used for a preliminary sizing of the AD.

\subsubsection{Population basis}

Digestion tanks can be designed based on a certain volume (in $\mathrm{m}^{3}$ ) per capita. Table 2 lists some typical design values. The per capita loading factors should only be used for the preliminary digester sizing since it presumes constant values for different important parameters e.g. solids removal efficiency. These parameters can vary considerably from one WWTP to another. If industrial waste loads are part of the wastewater influent, the values of Table 2 for capita design criteria should be increased on a population-equivalent basis [18].

\subsubsection{Volumetric solids loading}

One of the most common methods in defining the digester volume is the volatile suspended solids (VSS) loading rate as given in Table 2. The design criteria are commonly based on continuous loading conditions, typically on the basis of monthly peak of the 2-week peak solids production. Low solids loadings decrease the efficiency of the digester [6,18].

\subsubsection{Solids retention time (SRT)}

The digester volume can also be defined on the basis of the solids retention time since the digestion process is a function of the time required by the micro-organisms to digest the organic material and to reproduce. In ADs without recycle or supernatant withdrawal, the SRT is equal to the hydraulic retention time. The shortest SRT for a digestion temperature of $35^{\circ} \mathrm{C}$ is 10 days to prevent washout of the micro-organisms. For SRT values exceeding 12-13 days (at $35^{\circ} \mathrm{C}$ ), changes in increasing volatile solids destruction are relatively small. In selecting the design SRT for AD, the peak hydraulic load must be taken into account. Table 3 gives the critical SRT values that should be respected when using the SRT as a design criterion. Since these values were established in
Table 3

Suggested SRT for the design of completely mixed high-rate digesters [6]

\begin{tabular}{|c|c|c|}
\hline $\begin{array}{l}\text { Operating temperature } \\
\left({ }^{\circ} \mathrm{C}\right)\end{array}$ & Minimum SRT (d) & $\begin{array}{l}\text { Minimum design } \\
\mathrm{SRT}_{\text {des }}(\mathrm{d})\end{array}$ \\
\hline 18 & 11 & 28 \\
\hline 24 & 8 & 20 \\
\hline 30 & 6 & 14 \\
\hline 35 & 4 & 10 \\
\hline 40 & 4 & 10 \\
\hline
\end{tabular}

Table 4

Volatile solids destruction in high-rate fully mixed mesophilic anaerobic digesters [6]

\begin{tabular}{ll}
\hline Digestion time (d) & Volatile solids destruction (\%) \\
\hline 30 & 65.5 \\
20 & 60.0 \\
15 & 56.0 \\
\hline
\end{tabular}

ideal conditions of temperature, mixing and feeding, a safety margin should be provided when selecting the design SRT and in practice, a multiplication factor of about minimum 2.5 is recommended $[6,18]$.

\subsubsection{Volatile solids reduction}

During the digestion process, volatile solids are degraded to a certain extent and converted into biogas. The sludge volume is hereby reduced and the supernatant is returned to the plant. The degree of stabilisation is often expressed as the percent reduction in volatile solids, itself associated with either the SRT or the detention time based on the untreated sludge feed.

The MDS content is assumed to stay constant during the entire digestion period.

The following empirical equation allows the estimation of the amount of volatile solids destroyed [6]:

$V_{d}=13.7 \times \ln \left(S R T_{\text {des }}\right)+18.9$

where $V_{d}$ is the volatile solids destruction (\%) and $S R T_{\text {des }}$ the time of digestion (d).

The destruction of volatile solids can also be estimated using the values of Table 4 . This method is frequently used since the flow rate of the untreated sludge can easily be measured.

\subsubsection{Gas production}

Digester gas contains about 65-70\% methane, 30-35\% carbon dioxide and trace amounts of nitrogen, hydrogen, hydrogen sulphide and water vapour. It has a relative density of around 0.86 . With an average concentration of $65 \%$ methane, the heating value is approximately $21-25 \mathrm{MJ} / \mathrm{m}^{3}$, about $30-40 \%$ lower than the heating value of $37.3 \mathrm{MJ} / \mathrm{m}^{3}$ for natural gas.

The methane generation rate can be estimated from the kinetic equations developed for the ADs [7]:

$P_{x}=\frac{Y E S_{o}}{1+k_{d} \theta_{c}}$

$V=0.35 \mathrm{~m}^{3} / \mathrm{kg}\left\{\left[E S_{0}\right]-1.42\left(P_{x}\right)\right\}$

where $P_{X}$ is the net mass of cell produced $(\mathrm{kg} / \mathrm{d})$ and $Y$ the yield coefficient $(\mathrm{g} / \mathrm{g})$. For municipal sludge: $0.04-0.1 \mathrm{mg} \mathrm{VSS} / \mathrm{mg}$ BOD utilised, $E$ the efficiency of waste utilisation (0.6-0.9), $S_{o}$ the ultimate $\mathrm{BOD}_{L}$ of the influent sludge $(\mathrm{kg} / \mathrm{d})$ and $k_{d}$ the endogenous coefficient $\left(\mathrm{d}^{-1}\right)$. For municipal sludge: $0.02-0.04 \mathrm{~d}^{-1}, \Theta_{c}$ the 
a

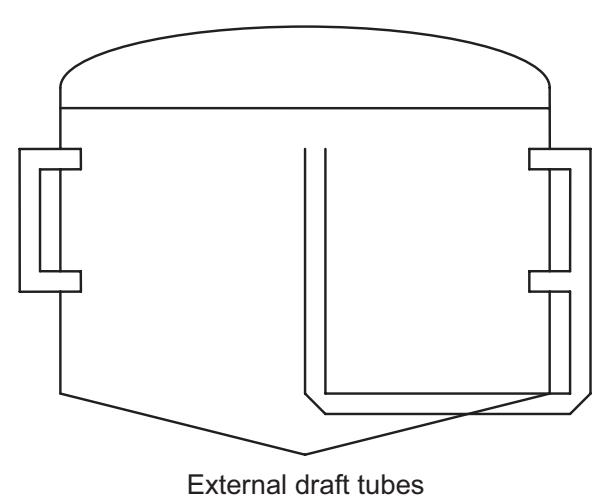

b

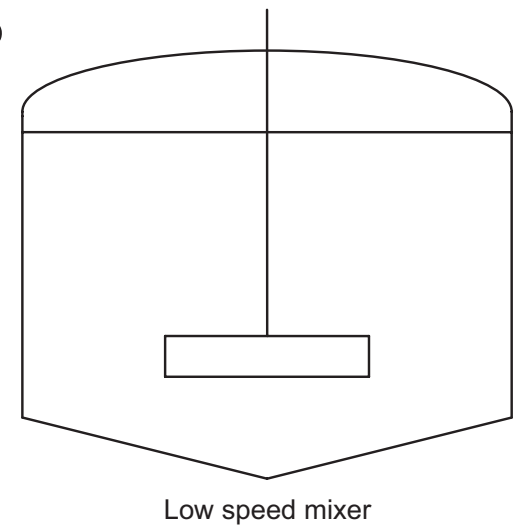

C
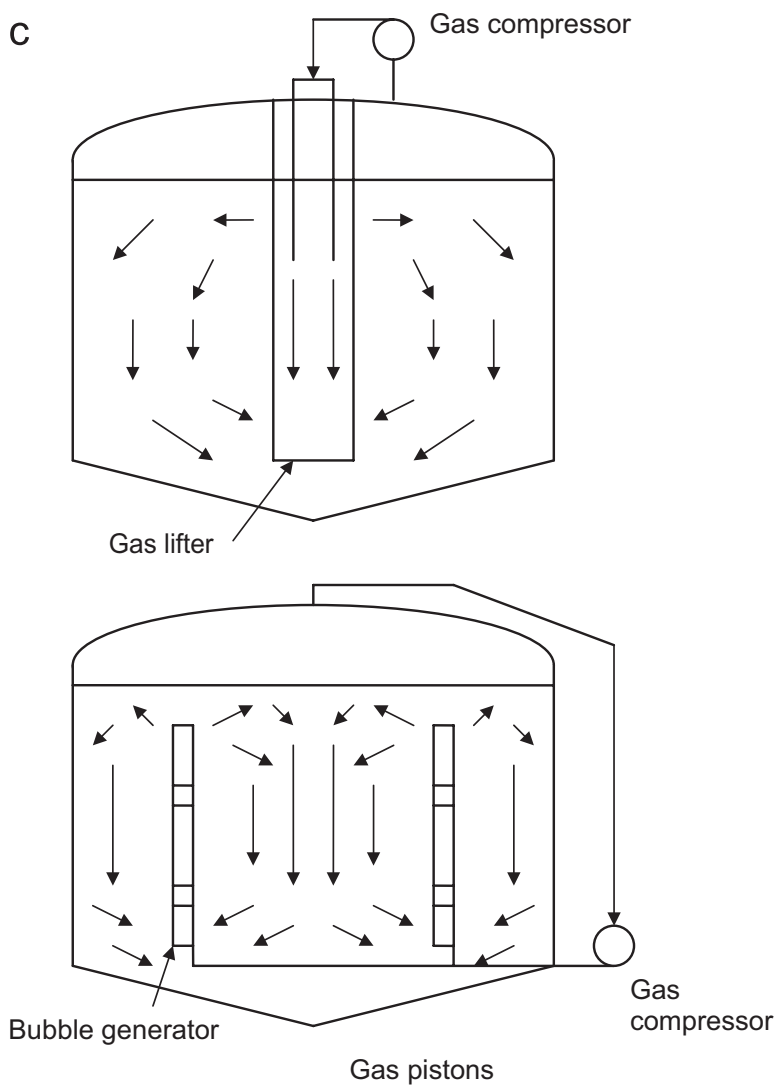

Fig. 7. Types of digester mixing (a) external, pumped recirculation, (b) internal, mechanical mixing, and (c) external, gas recirculation.

mean cell residence time (d), equal to the SRT, $V$ the volume of methane produced $\left(\mathrm{m}^{3} / \mathrm{d}\right), 0.35$ the theoretical conversion factor for the amount of methane produced from the conversion of $1 \mathrm{~kg}$ BOD and 1.42 the conversion factor for cellular material into BOD.

The specific gas production [6,7] lies in the range of $0.75-1.12 \mathrm{~m}^{3} / \mathrm{kg}$ VS destroyed, or $0.5-0.75 \mathrm{~m}^{3} / \mathrm{kg}$ VS loading, or $0.03-0.04 \mathrm{~m}^{3} /$ person day.

\subsubsection{Tank design}

AD tanks are mostly cylindrical or egg shaped [7]. The cylindrical tank has a diameter from 6 to $40 \mathrm{~m}$, a conical floor with a slope of about $15 \%$, and a withdrawal of the sludge in the centre of the tank. The water depth has to be minimum $7.5 \mathrm{~m}$ to allow proper mixing and can be as high as $15 \mathrm{~m}$. Some digesters are equipped with a so-called "waffle" bottom to minimise grit accumulation and reduce digester cleaning $[6,7,18]$. The design of egg-shaped digester tanks has been discussed in literature $[6,7,18]$.

\subsubsection{Digester mixing}

Proper mixing of the AD is essential for providing an optimum performance. Mixing provides intimate contact between the feed sludge and active biomass, yielding uniformity of temperature, of substrate concentration, of other chemical, physical and biological aspects throughout the digester, and preventing both the formation of surface scum layers and the deposition of sludge on the bottom of the tank. Due to the rise of gas bubbles and the thermal convection currents created by the addition of heated sludge, there is always some degree of natural mixing in the digestion tank. However, despite being the largest component, this is not sufficient for an optimum performance; therefore, auxiliary mixing is needed. Methods of auxiliary mixing are external pumped recirculation, internal mechanical mixing and internal gas mixing [7,14,22], as illustrated in Fig. 7.

2.4.7.1. External pumped recirculation. In external pumped recirculation a large amount of the digesting sludge withdrawn from the centre of the digester is pumped through external heat exchangers where the digested sludge is blended with the raw sludge and heated. It is then pumped back in the digestion tank through nozzles at the base of the digester or at the top to break the scum [7,23]. The flow rate in the recirculation should, however, be very large for ensuring a complete mixing of the tank which limits the sole use of this method of mixing. The minimum power required is $0.005-0.008 \mathrm{~kW} / \mathrm{m}^{3}$ of digester volume and may be higher, if friction losses are excessive. Other disadvantages of external pumped recirculation are plugging of the pumps by rags, impeller wear from grit and bearing failures [18,23].

2.4.7.2. Internal mechanical mixing. Mechanical stirring systems generally use low-speed flat-blade turbines. In both systems, the sludge is transported by the rotating impeller(s), thereby mixing the content of the digestion tank. The mechanical pumping action is provided by centrifugal pumps, generally set up in an internal or external shaft tube to support vertical mixing. Mixing is supported by the circulation of the sludge. These systems are most suited for digesters with fixed covers $[6,7,18]$.

2.4.7.3. Internal gas mixing. This is a successful method of mixing the digester content and avoid the build-up of scum. Gas mixing systems can be confined and unconfined. In unconfined systems, the gas is collected at the top of the digestion tank, compressed and then released through a pattern of diffusers or a series of radially placed lances suspended from the digester cover. 
Table 5

Typical design parameters for anaerobic digester mixing systems [6]

\begin{tabular}{|c|c|c|c|}
\hline Parameters & $\begin{array}{l}\text { Type of mixing } \\
\text { system }\end{array}$ & Typical values & Unit \\
\hline Unit power & Mechanical systems & $0.005-0.008$ & $\begin{array}{l}\mathrm{kW} / \mathrm{m}^{3} \text { of } \\
\text { digester } \\
\text { volume }\end{array}$ \\
\hline \multirow[t]{3}{*}{ Unit gas flow } & Gas mixing & & \\
\hline & Unconfined & $0.0045-0.005$ & $\mathrm{~m}^{3} / \mathrm{m}^{3} \min$ \\
\hline & Confined & $0.005-0.007$ & $\mathrm{~m}^{3} / \mathrm{m}^{3} \mathrm{~min}$ \\
\hline Velocity gradient $G$ & All & $50-80$ & $\mathrm{~s}^{-1}$ \\
\hline $\begin{array}{l}\text { Turnover time of } \\
\text { tank contents }\end{array}$ & $\begin{array}{l}\text { Confined gas mixing } \\
\text { and mechanical } \\
\text { systems }\end{array}$ & $20-30$ & $\min$ \\
\hline
\end{tabular}

The digester content is mixed, releasing gas bubbles that rise and push the sludge to the surface. Scum has to be specifically controlled as it causes roof fracture, gas surging, etc. The lance system is successful against the build-up of scum; however, due to an ineffective mixing regime there is a greater risk of solids deposits. The opposite occurs with the diffuser system: top mixing is not adequate, resulting in a scum build-up. This system is, however, effective against solids deposition. On the other hand, there is a possibility of diffuser plugging, which results in digester drainage for tank cleaning. The unit gas flow requirement for unconfined systems is $0.0045-0.005 \mathrm{~m}^{3} / \mathrm{m}^{3} \min [18]$.

There are two different types of confined systems: the gas lifter and the gas piston. Generally, in confined systems the gas is collected at the top, compressed and discharged through confined tubes. The gas lifter system is composed of flooded gas pipes placed in an eductor tube or gas lifter. The compressed gas is released from these pipes and gas bubbles rise, creating an air-lift effect. The gas piston system releases gas bubbles intermittently at the bottom of the piston, hereby creating piston pumping action of the bubbles and pushing the sludge to the surface. These confined systems generally have a low power requirement and a gas flow rate of $0.005-0.007 \mathrm{~m}^{3} / \mathrm{m}^{3} \min [6,18]$.

Table 5 shows some typical design parameters for digester mixing systems.

\subsubsection{Heating and temperature control}

It is crucial for a stable and efficient operation to maintain a constant digestion temperature. Heat is necessary to (i) raise the incoming sludge to the temperature of the digestion tank and (ii) compensate for heat loss through walls, floor and roof of the digester [6].

2.4.8.1. Heating requirements. The amount necessary to heat the sludge to the temperature of the digester is given by the following equation:

$Q_{1}=W_{f} C_{p}\left(T_{2}-T_{1}\right)$

where $Q_{1}$ is the heat required $(\mathrm{J} / \mathrm{d}), W_{f}$ the feed sludge rate $(\mathrm{kg} / \mathrm{d})$, $C_{p}$ the specific heat of the sludge $\left(4200 \mathrm{~J} / \mathrm{kg}^{\circ} \mathrm{C}\right), T_{2}$ the operating temperature of digester $\left({ }^{\circ} \mathrm{C}\right)$ and $T_{1}$ the temperature of feed sludge $\left({ }^{\circ} \mathrm{C}\right)$.

The amount of heat required to compensate heat losses is given by

$Q_{2}=U A\left(T_{2}-T_{a}\right)$

where $Q_{2}$ is the heat loss $(\mathrm{J} / \mathrm{s}), U$ the heat transfer coefficient $\left(\mathrm{W} / \mathrm{m}^{2}{ }^{\circ} \mathrm{C}\right), A$ the surface area of digester through which heat losses occur $\left(\mathrm{m}^{2}\right), T_{2}$ the temperature of sludge in digester $\left({ }^{\circ} \mathrm{C}\right)$ and $T_{a}$ the ambient temperature (outside digester) $\left({ }^{\circ} \mathrm{C}\right.$ )
Data for heat transfer coefficients are given in literature [24] for wall, floor and roof constructions, with or without insulation.

2.4.8.2. Heating equipment. The most common method for heating the sludge is the external heat exchanger, although steam injection can also be applied [6,7,18].

Steam injection heating requires no heat exchanger, but the presence of a steam boiler is not common to WWTPs.

External heat exchangers have the benefit of enabling to mix recirculating digester sludge with raw sludge before heating, and in seeding the raw sludge with anaerobic micro-organisms. Although there are three types of external heat exchangers frequently used, i.e. water bath, tubular and spiral exchanger, both tubular and spiral exchangers are favoured for their countercurrent flow design and heat transfer coefficients in the range of $850-1000 \mathrm{~W} / \mathrm{m}^{2} \mathrm{~K}$. The hot water used in the heat exchangers is commonly produced in a boiler driven by digester gas. At start-up and/or under conditions of insufficient biogas production, provisions for burning an alternative fuel source such as natural gas must be made [7].

\subsubsection{Digester covers}

Digesters are covered to maintain operating temperature and anaerobic conditions and of course to collect the digester gas. The cover can be either fixed or floating. When sludge is withdrawn, no air should be allowed to enter the digestion tank to avoid explosion danger through mixing of oxygen and digester gas. Fixed covers are dome shaped or flat and are made of reinforced concrete, steel or fibreglass-reinforced polyester. Floating covers are normally used for single-stage digester and for the second stage of two-stage digesters. A variation of the floating cover is the floating gas holder, consisting of a floating cover with an extended skirt, so that gas can be stored during periods when the supply of digester gas exceeds the demand. A recent development in gasholder covers is the membrane cover. It consists of supported, flexible gas and air membranes. When the gas storage volume decreases or increases in the space between the liquid surface and the membranes, the space between the membranes is pressurised or depressurised using an air-blower bleed-valve system [18]. Floating covers directly float on the liquid and generally have a maximal vertical ravel of $2-3 \mathrm{~m}$ [6,7]. The gas pressure under a digester cover is typically in the range of $0-3.7 \mathrm{kN} / \mathrm{m}^{2}$ [7]. In eggshaped digesters, there is only limited storage available for gas and the provision of external gas storage is needed [18].

\section{Modelling}

\subsection{Introduction}

The optimisation of the $\mathrm{AD}$ and the assessment of its operation as a function of varying feed or operating conditions are important objectives and can be pursued by using appropriate digestion models. These models can be of steady-state mode (i) to estimate retention time, reactor volume, gas production and composition for a requested system performance, (ii) to investigate the sensitivity of the system performance to various parameters, (iii) to provide cross-checking of simulation results and plant performance, and (iv) to determine how the digestion process can affect the design of upstream or downstream WWTP operations.

More complex dynamic models could be integrated in plantwide modelling, predicting on a time basis how the system will react to sudden or progressive changes in operating parameters of feedstock flow rate and composition, temperature, inhibition, $\mathrm{pH}$, etc. [25-27]. 
It is finally important to note that modelling will also be the guideline to develop, apply and validate digestion in-line monitoring.

The number of models presented in literature is extensive, and often of very specific nature. The most frequently used model, ADM1 developed by the IWA [11], forms a good basis and is often used in expanded models, as proposed by, e.g. Sötemann et al. $[28,29]$. Simpler models for digestion have been proposed by, e.g. Bala [30], Siegrist [31] and others. Due to the complexity of the models, the present review will be limited to the essential features, giving the interested reader ample references to published research.

\subsection{Simple models and principal kinetics}

Most initial models were based on a single rate-limiting step, which itself may be dependent on various conditions such as wastewater characteristics, hydraulic loading and temperature [32]. Some models considered acetogenic methanogenesis as the rate-limiting step [33], whereas others considered the conversion of fatty acids [34], or the hydrolysis of biodegradable suspended solids [35]. Pavlostathis and Gossett [36] studied, developed and evaluated a comprehensive kinetic model capable of predicting digester performance when fed biological sludge. Preliminary conversion mechanisms such as cell death, lysis, and hydrolysis responsible for rendering viable biological sludge organisms to available substrate were studied in depth. The results of this study indicate that hydrolysis of the dead, particulate biomass-primary consisting of protein-is the slowest step and therefore kinetically controls the overall process of $\mathrm{AD}$ of biological sludge. This rate control by hydrolysis was confirmed by several authors, including, e.g. Hiderani et al. [37], who used anaerobic respirometry to determine digestion kinetics. Additional data are given in [12,16,38-45].

The developed models are simple but do not very accurately describe the digester behaviour.

Additional literature deals with the modelling of biofilm reactors. The reader is referred to the literature [46-48].

Table 6 reviews the key AD models that have been developed so far. Some models have assumed various forms of the kinetics, the bacterial groups, occurring processes, rate-limiting steps and possible inhibition.

\subsection{The IWA AD model No. 1 (ADM1)}

The ADM1 model, initially developed by the IWA-ADM Test Group [56] was presented in book form [11]. This book presents the outcome of the study undertaking and is the result of 4 years of collaborative work by a number of international experts from various fields of anaerobic process technology. The approach provides a unified basis for $\mathrm{AD}$ modelling and promotes the increased application of modelling and simulation as a tool for research, design, operation and optimisation of anaerobic processes. The ADM1 model was developed on the basis of the extensive but often disparate work in modelling and simulation of AD systems over the previous 20 years. In developing the ADM1, the Task Group tried to establish common nomenclature, units and model structure, consistent with existing anaerobic modelling literature and the popular-activated sludge models [62]. Outputs from the model include common process variables such as gas flow and composition, $\mathrm{pH}$, separate organic acids, and ammonium. The structure encourages specific extensions or modifications where required, but still maintaining a common platform. The model structure is presented in a readily applicable matrix format for implementation in many available differential equation solvers.

The ADM1 includes biochemical as well as physicochemical processes. The biochemical part includes all three overall biological (cellular) steps, i.e. acidogenesis, acetogenesis of both VFA and LCFAs, and methanogenesis) as well as an extracellular (partly non-biological) disintegration step and an extracellular hydrolysis step. The physicochemical equations describe ion association and dissociation, and gas-liquid transfer.

The biochemical part of the model uses the following basis:

- All biochemical extracellular steps are assumed of first order.

- Substrate uptake use Monod-type kinetics as the basis for all intracellular biochemical reactions.

- Biomass growth is implicit in substrate uptake.

- Death of biomass is represented by first-order kinetics.

- Inhibition by $\mathrm{pH}$, hydrogen and free ammonia is included.

The physicochemical factors taken into account are:

- liquid-liquid reactions;

- gas-liquid exchanges.

For the full model equations, the reader is referred to [56]. The model has been successfully tested on a range of systems from full-scale waste sludge digestion to laboratory-scale thermophilic high-rate UASB reactors [63-68]. Various modifications have been developed with the ADM1 as a basis. These extended models were reviewed by Batstone et al. [69] and amongst the most promising expansions, the reader is referred to Sötemann et al. [28,29], Zaher et al. [63] and Blumensaat and Keller [70].

For possible connections with the activated sludge models ASM1, ASM2, ASM2d and ASM3, the reader is referred to IWA [62] and Henze et al. [71].

The approach of Sötemann et al. [28,29] is very comprehensive. As an alternative to characterising the sewage sludge feed into carbohydrates, proteins and lipids, as is done in ADM1, it is characterised in terms of total COD, its particulate nonbiodegradable COD fraction, the short chain fatty acid (SCFA) COD and the CHON content of the particulate organics, i.e. $X, Y, Z$ and $A$ in $\mathrm{C}_{X} \mathrm{H}_{Y} \mathrm{O}_{Z} \mathrm{~N}_{A}$. Having thus characterised the sludge in terms of measurable parameters, the model allows COD, $\mathrm{C}$ and $\mathrm{N}$ mass balances to be set up over the $\mathrm{AD}$ system. The interactions between the biological processes and weak acid/base chemistry are predicted for stable steady-state operation of ADs. The model of Sötemann et al. is a steady-state model, validated only for conditions of steady flow and load. The model equations can however be transformed to predict the digestion under dynamic operating conditions.

All kinetic and stoichiometric constants in the model, except those for hydrolysis, were obtained from the literature so that model calibration is reduced to determining the non-biodegradable particulate COD fraction of the sewage sludge, the associated constants of the hydrolysis kinetics and the sewage sludge $\mathrm{CHON}$ composition.

Various formulations for the hydrolysis rate of sewage sludge particulate biodegradable organics were evaluated and surfacemediated reaction (Contois) kinetics were selected similar to that used by Dold et al. [72] and ASM1 [73] for slowly biodegradable organics in activated sludge systems. Once calibrated against the Izzett et al. [74] data, this formulation showed the required sensitivity of gas production and unfiltered effluent COD concentration to variation in retention time, without changing the constants in the hydrolysis rate equation.

The influent COD, organic $\mathrm{N}$ and VSS measurements of Izzett et al. [74] determined the stoichiometric formulation of the influent 
Table 6

Overview of anaerobic digestion models

\begin{tabular}{|c|c|c|c|c|c|}
\hline Model & Kinetics & Bacterial groups & Processes & Limiting step & Included inhibition \\
\hline Graef and Andrews [49] & Andrews & Acetoclastic methanogens & Methanogenesis & Methanogenesis & $\begin{array}{l}\text { Unionised VFA, toxic } \\
\text { compounds }\end{array}$ \\
\hline \multirow[t]{2}{*}{$\begin{array}{l}\text { Kleinstruer and Powegha } \\
\text { [50] }\end{array}$} & Andrews & Acid-forming bacteria & Acetogenesis & Methanogenesis & $\begin{array}{l}\text { Unionised acetate, toxic } \\
\text { compounds }\end{array}$ \\
\hline & Andrews & Methane-forming bacteria & Methanogenesis & & $\begin{array}{l}\text { Unionised acetate, toxic } \\
\text { compounds }\end{array}$ \\
\hline \multirow[t]{2}{*}{ Moletta et al. [51] } & Andrews & Acidogenic bacteria & Acetogenesis & Methanogenesis & Unionised acetate \\
\hline & & Methanogenic bacteria & Methanogenesis & & Unionised acetate \\
\hline \multirow[t]{3}{*}{ Smith et al [52] } & First order & & Hydrolysis & Methanogenesis & \\
\hline & First order & Acidogenic bacteria & Acidogenesis & & Total VFA \\
\hline & Andrews & Methanogenic bacteria & Methanogenesis & & Unionised VFA \\
\hline \multirow[t]{4}{*}{ Bryers [53] } & First order & & Hydrolysis & Acetogenesis & - \\
\hline & Monod & Acid-forming bacteria & Acidogenesis & & - \\
\hline & Monod & $\begin{array}{l}\text { Propionic acid-utilising } \\
\text { bacteria }\end{array}$ & Acetogenesis & & - \\
\hline & Monod & Methanogenic bacteria & Methanogenesis & & - \\
\hline \multirow[t]{6}{*}{ Siegrist et al. [31] } & First order & & Hydrolysis & Acetogenesis & $\mathrm{H}_{2}$, acetate \\
\hline & Monod & Acidogenic bacteria & $\begin{array}{l}\text { Fermentation of amino acids } \\
\text { and sugars }\end{array}$ & & $\mathrm{H}_{2}$, acetate \\
\hline & Monod & Acetogenic bacteria & $\begin{array}{l}\text { Anaerobic oxidation of } \\
\text { fatty acids }\end{array}$ & & $\mathrm{pH}$ \\
\hline & Monod & Acetogenic bacteria & $\begin{array}{l}\text { Anaerobic oxidation } \\
\text { of propionate }\end{array}$ & & Free $\mathrm{NH}_{3}$ \\
\hline & Monod & Acetoclastic methanogens & $\begin{array}{l}\text { Acetate conversion } \\
\text { to methane }\end{array}$ & & $\mathrm{pH}$ \\
\hline & Monod & $\begin{array}{l}\text { Hydrogenotrophic } \\
\text { methanogens }\end{array}$ & $\begin{array}{l}\text { Hydrogen conversion } \\
\text { to methane }\end{array}$ & & $\mathrm{pH}$ \\
\hline \multirow[t]{5}{*}{ Mosey [54] } & Monod & Acid-forming bacteria & Acidogenesis & & $\mathrm{H}_{2}$ \\
\hline & Monod & $\begin{array}{l}\text { Propionic acid-utilising } \\
\text { bacteria }\end{array}$ & Acetogenesis & Acetogenesis & $\mathrm{H}_{2}$ \\
\hline & Monod & Butyric acid-utilising bacteria & Acetogenesis & & $\mathrm{H}_{2}$ \\
\hline & Monod & Acetoclastic methanogens & Methanogenesis & & \\
\hline & Monod & $\begin{array}{l}\text { Hydrogenotrophic } \\
\text { methanogens }\end{array}$ & Methanogenesis & & \\
\hline \multirow[t]{6}{*}{ Costello [55] } & Monod & Acid-forming bacteria & Acidogenesis & & $\mathrm{H}_{2}, \mathrm{pH}$ products ?? \\
\hline & Monod & Lactic acid-utilising bacteria & Acidogenesis & & $\mathrm{H}_{2}, \mathrm{pH}$ products \\
\hline & Monod & $\begin{array}{l}\text { Propionic acid-utilising } \\
\text { bacteria }\end{array}$ & Acetogenesis & Acetogenesis & $\mathrm{H}_{2}, \mathrm{pH}$ products \\
\hline & Monod & Butyric acid-utilising bacteria & Acetogenesis & & $\mathrm{H}_{2}, \mathrm{pH}$ products \\
\hline & Monod & Acetoclastic methanogens & Methanogenesis & & $\mathrm{pH}$ \\
\hline & Monod & $\begin{array}{l}\text { Hydrogenotrophic } \\
\text { methanogens }\end{array}$ & Methanogenesis & & $\mathrm{pH}$ \\
\hline \multirow[t]{8}{*}{ Batstone et al. [56] } & First order & & Disintegration & & $\mathrm{pH}$ \\
\hline & First order & & Hydrolysis & Hydrolysis & $\mathrm{pH}$ \\
\hline & Monod & Sugar-degrading acidogens & Acidogenesis & & $\mathrm{pH}$ \\
\hline & Monod & $\begin{array}{l}\text { Amino acid-degrading } \\
\text { acidogens }\end{array}$ & Acidogenesis & & $\mathrm{pH}$ \\
\hline & Monod & $\begin{array}{l}\text { Propionate-utilising } \\
\text { acetogens }\end{array}$ & Acetogenesis & & $\mathrm{pH}, \mathrm{H}_{2}$ \\
\hline & Monod & $\begin{array}{l}\text { Butyrate and valerate- } \\
\text { utilising acetogens }\end{array}$ & Acetogenesis & & $\mathrm{pH}, \mathrm{H}_{2}$ \\
\hline & Monod & Acetoclastic methanogens & Methanogenesis & & $\mathrm{pH}$, free $\mathrm{NH}_{3}$ \\
\hline & Monod & $\begin{array}{l}\text { Hydrogenotrophic } \\
\text { methanogens }\end{array}$ & Methanogenesis & & $\mathrm{pH}$, free $\mathrm{NH}_{3}$ \\
\hline \multirow[t]{2}{*}{ Kiely et al. [57] } & Monod & & Hydrolysis/acidogenesis & & $\mathrm{NH}_{3}$ \\
\hline & Monod & & Aceticlastic methanogenesis & & \\
\hline Lokshina and Vavilin [58] & Andrews & & $\begin{array}{l}\text { Propionate degradation } \\
\text { Acetate degradation }\end{array}$ & & $\begin{array}{l}\text { Propionate degradation } \\
\text { Acetate degradation }\end{array}$ \\
\hline Nopharatana et al. [59] & $\begin{array}{l}\text { Contois } \\
\text { Mass balance, } \\
\text { stoichiometry }\end{array}$ & $\begin{array}{l}\text { Acid-producing bacteria } \\
\text { Acidogenic bacteria } \\
\text { Acetoclastic methanogens }\end{array}$ & $\begin{array}{l}\text { Hydrolysis } \\
\text { Acidogenesis } \\
\text { Methanogenesis }\end{array}$ & Hydrolysis & \\
\hline
\end{tabular}


Table 6 (continued)

\begin{tabular}{|c|c|c|c|c|c|}
\hline Model & Kinetics & Bacterial groups & Processes & Limiting step & Included inhibition \\
\hline \multirow[t]{6}{*}{ Pontes and Pinto [60] } & Monod & Fermentors & Acidogenesis & & $\mathrm{pH}, \mathrm{VFA}, \mathrm{H}_{2}$ \\
\hline & Monod & $\begin{array}{l}\text { Butyric acid-utilising } \\
\text { acetogens }\end{array}$ & Acetogenesis & & \\
\hline & Monod & Ethanol-utilising acetogens & Acetogenesis & & \\
\hline & Monod & Acetoclastic methanogens & Methanogenesis & & \\
\hline & Monod & $\begin{array}{l}\text { Hydrogenotrophic } \\
\text { methanogens }\end{array}$ & Methanogenesis & & \\
\hline & & Endogenous residue & & & \\
\hline \multirow[t]{7}{*}{ Siegrist et al. [61] } & Mathematical & & Biogas stripping & & \\
\hline & First order & & Hydrolysis & & $\mathrm{pH}$, free $\mathrm{NH}_{3}, \mathrm{H}_{2}$, acetate \\
\hline & Monod & & Fermentation & & $\mathrm{pH}$, free $\mathrm{NH}_{3}, \mathrm{H}_{2}$, acetate \\
\hline & Monod & & Anaerobic oxidation of LCFA & & $\mathrm{pH}$, free $\mathrm{NH}_{3}, \mathrm{H}_{2}$, acetate \\
\hline & Monod & & $\begin{array}{l}\text { Anaerobic oxidation of } \\
\text { propionate }\end{array}$ & & $\mathrm{pH}$, free $\mathrm{NH}_{3}, \mathrm{H}_{2}$, acetate \\
\hline & Monod & Acetoclastic methanogens & Acetotrophic methanogenesis & & $\mathrm{pH}$, free $\mathrm{NH}_{3}, \mathrm{H}_{2}$, acetate \\
\hline & Monod & $\begin{array}{l}\text { Hydrogenotrophic } \\
\text { methanogens }\end{array}$ & $\begin{array}{l}\text { Hydrogentrophic } \\
\text { methanogenesis }\end{array}$ & & $\mathrm{pH}$, free $\mathrm{NH}_{3}, \mathrm{H}_{2}$, acetate \\
\hline \multirow[t]{6}{*}{ Sötemann et al. [28] } & $\begin{array}{l}\text { First order, } \\
\text { Monod, Contois }\end{array}$ & Acidogenic bacteria & Hydrolysis & Hydrolysis & \\
\hline & Monod & Glucose-utilising acidogens & Acidogenesis & & $\mathrm{H}_{2}$ \\
\hline & Monod & $\begin{array}{l}\text { Propionate-utilising } \\
\text { acidogens }\end{array}$ & Acidogenesis & & $\mathrm{H}_{2}$ \\
\hline & Monod & acetogenic bacteria & Acetogenesis & & $\mathrm{pH}, \mathrm{H}_{2}$ \\
\hline & Monod & $\begin{array}{l}\text { Acetoclastic methanogens on } \\
\text { acetic acid }\end{array}$ & Acetoclastic methanogenesis & & $\mathrm{pH}, \mathrm{H}_{2}$ \\
\hline & Monod & $\begin{array}{l}\text { Hydrogenotrophic } \\
\text { methanogens on } \mathrm{H}_{2}\end{array}$ & $\begin{array}{l}\text { Hydrogenotrophic } \\
\text { methanogenesis }\end{array}$ & & $\mathrm{pH}, \mathrm{H}_{2}$ \\
\hline
\end{tabular}

sewage sludge as $\mathrm{C}_{3.4} \mathrm{H}_{7} \mathrm{O}_{2} \mathrm{~N}_{0.192}$. With the sludge biodegradability and hydrolysis process rate defined, the anaerobic digester performance data of Ekama et al. [75] ranging over 7-20 day retention time (i.e. effluent COD, TKN, FSA, SCFA, $\mathrm{H}_{2} \mathrm{CO}_{3}{ }^{*} \mathrm{Alk}, \mathrm{pH}$, gaseous $\mathrm{CO}_{2}$ and $\mathrm{CH}_{4}$ production and partial pressures), could only be matched if the sewage sludge composition was refined to $\mathrm{C}_{1.5} \mathrm{H}_{7} \mathrm{O}_{2} \mathrm{~N}_{0.196}$ to conform to the COD, $\mathrm{C}$ and $\mathrm{N}$ mass balances of the data. This formulation was confirmed with primary sludge $\mathrm{CHON}$ composition tests, the average of which was $\mathrm{C}_{3.65} \mathrm{H}_{7} \mathrm{O}_{1.97} \mathrm{~N}_{0.19}$. The model predicts $\mathrm{CHON}$ content and molar masses close to $100 \%$, thereby provides persuasive validation of the UCTADM1 model.

Validation of the model under steady-state conditions validates only its stoichiometry and the system rate-limiting process, which is hydrolysis. However, the model, which includes the influence of high hydrogen partial pressure on the acidogenesis and acetogenesis processes, shows the expected sensitivity to a digester upset (although commonly unnoticed due to the system inertia) initiated by temporary inhibition of the acetoclastic methanogens, which is the usual cause in practise. The model demonstrates that even a brief inhibition of this organism group causes an irreversible failure of the digester $(\mathrm{pH}<6.6)$.

The successful integration in a kinetic way of the two-phase mixed weak acid/base chemistry and biological processes of the $\mathrm{AD}$ has provided a sound basis for further model development. Still to be included are mineral precipitation and the $\mathrm{P}$ content of sewage sludges. This will extend the model to digestion of biological excess $P$ removal waste-activated sludge and provide a direct and quantitative link between feed sludge composition and mineral precipitation problems, e.g. struvites in digesters.

Additional software has been presented by several authors or institutions, with the DESASS example [76] certainly worth exploring.

\subsection{Modelling, monitoring and regulation}

The previously mentioned models, and their validation, stress the importance of monitoring essential parameters during diges- tion. These essential parameters include $\mathrm{pH}$, alkalinity, VFA and biogas flow rate and composition. Again literature data are extensive and the quoted references of Table 7 illustrate the trend used in the monitoring and control of digestion plants.

\section{Inhibition}

Inhibiting compounds are either already present in the digester substrate or are generated during digestion.

\subsection{Ammonia}

Ammonia is produced during the degradation of nitrogenous matter, mainly proteins and urea [17,100]. Ammonium $\left(\mathrm{NH}_{4}^{+}\right)$and free ammonia $\left(\mathrm{NH}_{3}\right)$ are the two most predominant forms of inorganic nitrogen present. It has been indicated that free ammonia is the most toxic of both, due to the fact that it can pass through the cell membrane $[100,101]$ and into the cell, causing proton imbalance and potassium deficiency [100]. The free ammonia concentration mainly depends on three parameters: total ammonia concentration, temperature and $\mathrm{pH}$ [102]. An increased temperature has a positive effect on the microbial growth rate but also results in a higher (free) ammonia concentration. It is found that thermophilic digestion is more easily inhibited than mesophilic digestion [101,102]. An increase in $\mathrm{pH}$ would result in a higher toxicity level due to the shift to a higher ratio of free to ionised ammonia. The resulting instability of the process often leads to an increase in the amount of VFA, which again leads to a decrease in $\mathrm{pH}$ and consequently to a lower free ammonia concentration [100]: the process remains stable but the methane yield is reduced [101,102]. Ammonia concentrations below $200 \mathrm{mg} / \mathrm{l}$ are beneficial to $\mathrm{AD}$ because nitrogen is an essential nutrient for the micro-organisms [103]. Free ammonia of $560-568 \mathrm{mg} \mathrm{NH} \mathrm{NH}_{3} \mathrm{~N} / \mathrm{l}$ can cause a $50 \%$ inhibition of methanogenesis at pH 7.6 under thermophilic conditions [101]. The acetogenic population is more tolerant than the methanogens. When the 
Table 7

Review of programming, monitoring and control literature

\begin{tabular}{|c|c|c|}
\hline Author & Topic of investigation & \\
\hline Bernard et al. [77] & $\begin{array}{l}\text { Telemac: an integrated system to remote monitoring control anaerobic wastewater treatment plants through the } \\
\text { internet }\end{array}$ & Programming \\
\hline Lardon et al. [66] & $\begin{array}{l}\text { Methodological framework based on evidence theory to manage the fault signals generated by conventional } \\
\text { approaches }\end{array}$ & Programming \\
\hline Mailleret and Bernard [78] & A simple robust controller to stabilise an anerobic digestion process & Programming \\
\hline Alatiqi et al. [79] & $\begin{array}{l}\text { A control system including a proportional-integral (PI) controller and variable groups is proposed to analyse } \\
\text { mesophilic and thermophilic processes for process stability and controllability }\end{array}$ & Monitoring \\
\hline Alcaraz-Gonzalez et al. [80] & A robust asymptotic observer for chemical and biochemical reactions & Monitoring \\
\hline Bernard and Chachuat [81] & Design and practical use of probabilistic observers for mass balance-based bioprocess models & Monitoring \\
\hline Bernard and Gouze [82] & Multi-observateurs en boucle fermée pour des modèles biotechnologiques mal connus & Monitoring \\
\hline Chachuat et al. [83] & Design of probabilistic software sensors for anaerobic digestion & Monitoring \\
\hline De Pauw et al. [84] & Protocol and optimal experimental design to set up a monitoring and control system at an anaerobic digester & Monitoring \\
\hline Gomez et al. [85] & Monitoring anaerobic digestion processes using thermal analysis with mass spectrometry & Monitoring \\
\hline Liu et al. [86] & $\begin{array}{l}\text { A computer-controlled automated BOD-analyzer with the purpose of on-line monitoring of a process for } \\
\text { conversion of biomass under field conditions }\end{array}$ & Monitoring \\
\hline Steyer et al. [87] & Sensor networks and uncertainty management in anaerobic digestion processes & Monitoring \\
\hline Vanrolleghem and Lee [88] & On-line monitoring equipment for wastewater treatment processes: state of the art & Monitoring \\
\hline Yamaguchi et al. [89] & Enzyme activity for monitoring the stability in a thermophilic anaerobic digestion of wastewater & Monitoring \\
\hline Zaher et al. [90] & Titrimetric monitoring of anaerobic digestion: VFA, alkalinities and more & Monitoring \\
\hline Alcaraz-Gonzalez et al. [91] & Robust interval-based siso regulation in anaerobic digestion & Regulation \\
\hline Cresson et al. [47] & $\begin{array}{l}\text { Better control biofilm formation in order to reduce the time of colonization during the start-up phase of an } \\
\text { anaerobic high-rate biofilm reactor }\end{array}$ & Regulation \\
\hline Hess and Bernard [92] & Detection of the conditions of destabilisation in anaerobic wastewater treatment processes & Regulation \\
\hline Mailleret et al. [93] & Robust regulation of anaerobic digestion processes & Regulation \\
\hline Mailleret et al. [94] & Controle asymptotique non-linéaire des fermenteurs anaérobie & Regulation \\
\hline Mailleret et al. [95] & Robust nonlinear adaptive control for bioreactors with unknowm kinetics & Regulation \\
\hline Punal et al. [96] & Automatic control of VFA in anaerobic digestion using a fuzzy logic-based approach & Regulation \\
\hline Punal et al. [97] & $\begin{array}{l}\text { Compared fuzzy logic approaches for automatic control of } \mathrm{CH}_{4} \text { flow rate production and VFA effluent } \\
\text { concentrations in a digestion }\end{array}$ & Regulation \\
\hline Ruiz et al. [98] & Transient state detection and prediction of organic overload in anaerobic digestion process using statistic tool & Regulation \\
\hline Vanrolleghem et al. [99] & Continuity-based interfacing of models for wastewater systems described by Peterson matrices & Regulation \\
\hline
\end{tabular}

concentration of ammonia was increased to $4051-5734 \mathrm{mg} \mathrm{NH} / \mathrm{l}$, the acidogens were hardly affected whereas the methanogens lost $56.1 \%$ of their activity [100]. However, the methanogenic bacteria can be acclimated to ammonia inhibition as a result of a shift in the methanogenic population or because of internal changes in the predominant methanogenic species [100]. Sung and Liu [101] showed that the acclimated methanogens could tolerate concentrations up to $2 \mathrm{~g}-\mathrm{N} / \mathrm{l}$ under thermophilic conditions without inhibition, albeit with total inhibition of the methanogenic activity when a concentration of $10 \mathrm{~g}-\mathrm{N} / \mathrm{l}$ was reached.

\subsection{Sulphide}

Sulphate is commonly found in many wastewaters and hence in WAS [104]. Under anaerobic conditions, sulphate is used as an electron acceptor and hence reduced to sulphide by sulphate reducing bacteria (SRB) [17,100]. Two groups of SRB are responsible for the reduction, the incomplete and the complete oxidisers. The first group oxidises compounds like lactate to acetate and $\mathrm{CO}_{2}$, whereas the second one converts acetate to $\mathrm{CO}_{2}$ and $\mathrm{HCO}_{3}^{-}$ [100]. In both processes, the reduction half reaction transforms $\mathrm{SO}_{4}^{2-}$ into $\mathrm{S}^{2-}$.

Inhibition occurs at two different levels: the primary inhibition caused by the competition for substrates from SRB, whereas secondary inhibition is due to the toxicity of sulphides for the different groups of micro-organisms [100].

\subsubsection{Competition}

SRB can metabolise a number of substrates, such as alcohols, organic acids, aromatic compounds and long-chain fatty acids (LCFA). They compete with the fermentative, acetogenic or methanogenic bacteria for acetate, $\mathrm{H}_{2}$, propionate and butyrate in the digester system. Normally, inhibition through competition does not occur in the first stage of digestion since the SRB are not capable of degrading biopolymers. They depend on the fermentative micro-organisms to degrade these organics so they can metabolise the degradation products $[17,21,100]$. Nevertheless the acetogenic and the methanogenic micro-organisms are affected by the presence of SRB since they compete for the same fermentation products. When looking at it from a thermodynamic and kinetic point of view, the SRB should be able to overgrow the acetogens for the propionate and butyrate, but there are some factors like the $\mathrm{COD} / \mathrm{SO}_{4}^{2-}$ ratio, the sulphide toxicity and the relative population of SRB and the acetogens that influence the competition. SRB are utmost important in the degradation of propionate, it is even believed to be the key degradation pathway. The acetogens are capable of effectively competing with the SRB for butyrate and ethanol. Methanogenesis and sulphate reduction can happen simultaneously, but the hydrogenotrophic methanogens are easily undercut by the SRB for $\mathrm{H}_{2}[17,100]$. If wastewater with a high sulphate concentration is fed to a methane reactor, the population may gradually shift from hydrogenotrophic methanogens to hydrogenotrophic sulphate reducers, due to a more favourable $K_{s}$ value for hydrogen of the sulphate reducers $[17,21]$. Temperature has an effect on the competition between SRB and hydrogenotrophic methanogens. It appeared that SRB were dominant at mesophilic conditions and the methanogens had the largest population at thermophilic temperatures [100]. Contradictory data were reported in the literature regarding the competition between the acetoclastics and the SRB, with some authors finding an effective competition of methanogens, whereas others concluded that SRB are superior [100].

4.2.1.1. Toxicity. Non-dissociated hydrogen sulphide is toxic for both methanogens and sulphate reducers. This form is the toxic form since it can freely diffuse through the cell membrane, 
causing denaturation of proteins, interfering with the assimilatory metabolism of sulphur, etc. [17,100]. Concentrations as low as 0.003-0.006 mole/l total S or $0.002-0.003$ mole $/ 1 \mathrm{H}_{2} \mathrm{~S}$ are reported to be inhibitory to the micro-organisms [17], other sources suggest that with a concentration of $150 \mathrm{mg} / \mathrm{l}$ sulphide stable methanogenesis can occur [21]. There are authors who claim that the toxicity should be related to the unionised sulphide concentration in the $\mathrm{pH}$ range of 6.8-7.2 and to total sulphide concentration at a $\mathrm{pH}$ higher than $7.2[17,100]$. The range of sensitivity of the different anaerobic bacteria follows: fementative$\mathrm{s}<\mathrm{SRB}=$ acetogens $<$ methanogens.

\subsection{Sodium and potassium}

Various cationic elements, including $\mathrm{Na}, \mathrm{K}$ and others, are found in the digester influent, where they can be released due to the degradation of organic material or with compounds added for $\mathrm{pH}$ adjustment [100]. Although they are required for microbial growth, they can be toxic or inhibitory to the activity of the microorganisms when present in high concentrations.

\subsubsection{Sodium}

The presence of low concentrations of sodium is essential for the methanogenic bacteria, presumably because it is important for the formation of ATP or the oxidation of NADH. High concentrations of sodium, however, inhibit the activity of the micro-organisms and interfere with their metabolism [100,105]. The level of inhibition depends on the concentration found in the sludge. Optimal growth conditions of hydrogenotrophic methanogens occur at concentrations of $350 \mathrm{mg} \mathrm{Na}^{+} / 1$. Inhibitory effects start at concentrations between 3500 and $5500 \mathrm{mg} / \mathrm{l}$ causing a rather moderate inhibition, whereas a concentration $8800 \mathrm{mg} / \mathrm{l}$ is strongly inhibitory to methanogenic bacteria during mesophilic digestion [100]. If exposed a sufficient period of time, the anaerobic bacteria can acclimate to the toxic cation and their activity is not affected significantly. However, there is a limit for the micro-organisms to tolerate the high concentrations $[100,106]$. The adaptation or acclimation of the methanogenic bacteria to high concentrations of sodium is apparent when investigating the optimal sodium concentration in different saline media. In a medium with a low salt content the optimal concentration range is in the range $230-350 \mathrm{mg} / \mathrm{l}$ [105]. This fact is due to the adaptation of the sludge to sodium. VFA-degrading bacteria have a different resistance to sodium toxicity: it caused $50 \%$ inhibition of propionic acid, acetic acid and $n$-butyric acid utilising bacteria at concentrations 10,500, 7000, and 19,000 mg/l, respectively [105]. This is in agreement with the results of Liu and Boone [107], who found that acetate-utilising bacteria are more susceptible to the toxicity of $\mathrm{NaCl}$ than propionate-utilising and $\mathrm{H}_{2} / \mathrm{CO}_{2}$-utilising micro-organisms.

The simultaneous addition of calcium and potassium in suitable concentrations was found to be very beneficial in improving the efficiency of the anaerobic treatment process by reducing sodium toxicity to methanogens. For the highest reduction in sodium toxicity, the cations must be present in or very close to their optimum concentrations; 326 and $339 \mathrm{mg} / \mathrm{l}$ of potassium and calcium, respectively. Potassium and magnesium were also found to be very effective in reducing the toxicity of sodium when present in the optimum concentration. However, if the concentrations of the cations are too far from the optimum, their effect is irrelevant $[100,106,108]$.

4.3.1.1. Potassium. High concentrations of potassium can lead to the passive influx of potassium ions, thereby neutralising the membrane potential [100]. When the concentration of potassium is below $400 \mathrm{mg} / \mathrm{l}$, functioning in both mesophilic and thermophilic temperatures ranges are improved. However, higher potassium levels induce an inhibitory effect, especially for the thermophilic organims [100,109]. It was found that when using acetate and glucose as substrates together with sludge (inoculum), the half maximal inhibitory concentration $\left(\mathrm{IC}_{50}\right)$ for acetate-utilising bacteria was 0.74 mole/1 [100]. The bacteria can exhibit an acclimation effect, which depends on both concentration of potassium and exposure time. If allowed a sufficient time of exposure, the anaerobic bacteria can acclimate to the toxic cation and their activity is not affected significantly. However, beyond a certain level of the toxic cation, the bacteria can no longer tolerate. Sodium, magnesium, ammonium and calcium were found to be very effective in moderating the toxicity of potassium [109,110]. There are, however, optimal concentrations that should be respected to accomplish mitigation effects. For sodium, the optimum was found to be $564 \mathrm{mg} / \mathrm{l}$ [111]. Calcium and sodium should be present at 837 and $379 \mathrm{mg} / \mathrm{l}$, respectively [110].

The reader is referred to the literature for more information about the effects of other cations such as magnesium, calcium and aluminium $[100,109,112]$, and some overall data are given in Table 8 below.

\subsection{Heavy metals}

Industrial contributions are the primary source of heavy metals in urban wastewater and account for up to $50 \%$ of the total metal content in sewage sludge. Industrial contaminants include zinc, copper, chromium, nickel, cadmium and lead. Domestic sources are mainly associated with leaching from plumbing materials ( $\mathrm{Cu}$ and $\mathrm{Pb})$, gutters and roofs $(\mathrm{Cu}$ and $\mathrm{Zn}$ ) and galvanised materials, use of detergents and washing powders containing $\mathrm{Cd}, \mathrm{Cu}$ and $\mathrm{Zn}$, and use of body care products containing $\mathrm{Zn}$. The presence of heavy metals can often cause difficulties in the nitrification/denitrification step of the wastewater treatment processes due to inhibition [113] and may hamper the sludge disposal by land application [114]. The behaviour of heavy metals in wastewater and sludge treatment processes has been widely discussed in literature [100,109,115-120].

Some values of inhibitory concentrations of metals are also listed in Table 8.

Many enzymes and co-enzymes depend on a minimal amount of certain traces of metals for their activation and activity. When present in large amounts, they cause an inhibitory or toxic effect to micro-organisms. The chemical binding of heavy metals to the enzymes and subsequent disruption of the enzyme structure and function are the main cause of this toxic effect [121].

\subsection{Hydrogen}

Molecular hydrogen is formed during different stages of AD. In the hydrolysis stage the bacteria produce fatty acids, $\mathrm{CO}_{2}$ and hydrogen from carbohydrates. During the acetogenesis, bacteria (Syntrophobacter wolinii or Syntrophomonas wolfei) produce acetate, $\mathrm{CO}_{2}$ and hydrogen, or acetate and hydrogen by anaerobic oxidation of propionate and $n$-butyrate [21]. In this last stage, hydrogen can only be formed when it is consumed by methanogenic bacteria so it does not accumulate (reaction 1 ). This can also be achieved by the activity or sulphate reducing bacteria (reaction 2) via interspecies electron transfer [21]. The hydrogen concentration can also be decreased in sewage sludge by acetate formation from $\mathrm{CO}_{2}$ and $\mathrm{H}_{2}$ (reaction 3).

Acetogenesis of fatty acids or of other reduced metabolites may only function if hydrogen does not accumulate but is 
Table 8

Critical concentrations for various inhibitors $[18,20]$

\begin{tabular}{|c|c|c|c|}
\hline Substance & Stimulating concentration (mg/l) & Moderately inhibitory concentration (mg/l) & Strongly inhibitory concentration (mg/l) \\
\hline $\mathrm{Na}^{+}$ & & $3500-5500$ & 8000 \\
\hline $\mathrm{K}^{+}$ & $200-400$ & $2500-4500$ & 12,000 \\
\hline $\mathrm{Ca}^{2+}$ & $100-200$ & $2500-4000$ & 8000 \\
\hline $\mathrm{Mg}^{2+}$ & $75-150$ & $1000-1500$ & 3000 \\
\hline $\mathrm{NH}_{4}^{+}$ & & $1500-3500$ & 3000 \\
\hline $\mathrm{S}^{2-}$ & & 200 & 200 \\
\hline \multirow[t]{2}{*}{$\mathrm{Cu}^{2+}$} & & & 0.5 (soluble) \\
\hline & & & $50-70$ (total) \\
\hline \multicolumn{4}{|l|}{ Chromium } \\
\hline \multirow[t]{2}{*}{$\mathrm{Cr}^{6+}$} & & & 3.0 (soluble) \\
\hline & & 10 & $200-250$ (total) \\
\hline \multirow[t]{2}{*}{$\mathrm{Cr}^{3+}$} & & & 2.0 (soluble) \\
\hline & & & $180-240$ (total) \\
\hline $\mathrm{Ni}^{2+}$ & & & 30 (total) \\
\hline $\mathrm{Zn}^{2+}$ & & & 1.0 (soluble) \\
\hline Arseniate and arsenite & & $>0.7$ & \\
\hline Barium chloride & & - & \\
\hline Cyanide & & 1-2 (acclimatisation possible up to 50 ) & \\
\hline Lead-containing compounds & & 5 & \\
\hline Cadmium-containing compounds & & - & \\
\hline Iron-containing compounds & & $>35$ & \\
\hline Cupper-containing compounds & & 1 & \\
\hline Potassium chloride & & $>10,000$ (acclimatisation possible up to 40,000 ) & \\
\hline Nickel-containing compounds & & - & \\
\hline Chloride & & 6000 & \\
\hline
\end{tabular}

consumed by methanogens. In sludge digesters, the hydrogen concentration may be decreased by acetate formation from $\mathrm{CO}_{2}$ and $\mathrm{H}_{2}$.

Several studies determined the effect of hydrogen partial pressure $\mathrm{pH}_{2}$ on the production of acetic acid, propionic acid and butyric acid [122]. Conversions of propionic acid and butyric acid to acetic acid were found to be thermodynamically possible only when $\mathrm{pH}_{2}$ is less than $10^{-4}$ for $n$-butyric acid and $10^{-5}$ atm for propionic acid. They also indicated that when $\mathrm{pH}_{2}$ is higher than $10^{-4} \mathrm{~atm}$, the Gibbs free energy change is larger for $\mathrm{CO}_{2}$ reduction than for the acetate cleavage, resulting in a reduction of $\mathrm{CO}_{2}$ instead of a acetate cleavage. A decrease in $\mathrm{H}_{2}$ concentration allows conversion of acetic acid to methane to resume [21,122]. The methanogenic and sulphate reducing activity of the respective micro-organisms is not sufficient to maintain $\mathrm{pH}_{2}$ at the required level. However, by reversed electron transport electrons may be shifted to a lower ORP suitable for proton reduction [21].

A well-functioning, stable digester has a very low dissolved hydrogen concentration and converts most of the (organic) substrate to acetic acid [122].

\subsection{Volatile fatty acids}

VFA are the most important intermediates in the AD process, where they are degraded by proton-reducing acetogens in association with hydrogen consuming methanogenic bacteria [123]. However, the production of VFA can be toxic to micro-organisms, especially to methanogens at a concentration of $6.7-9.0 \mathrm{~mol} / \mathrm{m}^{3}$ [124]. These increased concentrations are the result of accumulation due to process imbalances which can be caused by variation in temperature, organic overloading, toxic compounds, etc. [123]. In such cases, the methanogens are not able to remove the hydrogen and volatile organic acids fast enough. As a result the acids accumulate and the $\mathrm{pH}$ decreases to such a low value that the hydrolysis/acetogenesis can be inhibited [125].

The toxicity is due to an increase in the undissociated form of the VFA. They can flow freely through the cell membrane where they dissociate and hence cause a $\mathrm{pH}$ reduction and a disruption of homoeostasis [17].

According to Siegert and Banks [125] the presence of increasing concentrations of VFA in a batch anaerobic reactor system have a differential effect on the metabolically distinct phases of hydrolysis, acidogenesis and biogas production. The tests were conducted on cellulose and on glucose as primary substrate for digestion. Independent of the system $\mathrm{pH}$, VFA caused inhibition of the cellulolytic hydrolysis at concentrations $2 \mathrm{~g} / \mathrm{l}$, while for glucose a concentration of more than $4 \mathrm{~g} / \mathrm{l}$ was observed to give the same effect. The inhibitory effect on the production of biogas was evident above $6 \mathrm{~g} / \mathrm{l}$ VFA for cellulose and $8 \mathrm{~g} / \mathrm{l}$ for glucose [125].

High concentrations of acetate and propionate inhibit their own degradation by sludge enrichments. Acetate also noncompetitively inhibits propionate degradation and uncompetitively inhibits benzoate degradation. VFA can enhance the inhibitory effect of $\mathrm{pH}$ on methane production and VFA degradation in anaerobic digesters [21].

\subsection{Long-chain fatty acids}

LCFAs are formed during the degradation of fat and lipids and are further reduced to acetate and hydrogen through $\beta$-oxidation by proton-reducing acetogens $[17,126]$. LCFAs are known to be inhibitory at low concentrations, for Gram-positive bacteria, and not for Gram-negative bacteria [100]. Angelidaki and Ahring [127] found that 18-C LCFA such as oleic acid and stearic acid are inhibitory at concentrations $1.0 \mathrm{~g} / \mathrm{l}$. They also found that the toxic effect was one of a permanent kind since growth did not reoccur when the concentrations in the culture were diluted to a noninhibitory one.

The mechanism of the LCFA toxicity is caused by adsorption onto the cell wall or cell membrane, which interferes with the transport and/or protection functions of the cell $[100,126]$. Moreover, the sorption of a layer of LCFA to biomass leads to flotation of sludge and sludge washout [100].

Acetoclastic methanogenis bacteria are reported to be more affected by the LCFA than the hydrogenotrophic methanogens 
[126] and thermophilic bacteria seem to be more sensitive to LCFA toxicity compared to their mesophilic colleagues. This is possibly related to the composition of the cell membrane, which is different for the two species [100].

Angelidaki and Ahring [127] found that LCFAs had a bactericidal effect and that the bacteria showed no sign of adaptation to the fatty acids toxicity. However, a study performed by Alves et al. [126] postulated that sludge acclimated with lipids showed a higher tolerance to oleic acid toxicity $\left(\mathrm{IC}_{50}=137 \mathrm{mg} / \mathrm{l}\right)$ compared with sludge that was fed a non-fat substrate $\left(\mathrm{IC}_{50}=80 \mathrm{mg} / \mathrm{l}\right)$. Also, the biodegradability of oleic acid was improved by this acclimatisation with lipids or oleate [126]. Oleic acid (C18:1) is the most abundant 'species' in LCFA-containing wastewater [128]. Values of the $\mathrm{IC}_{50}$ of oleate were obtained from a batch test and ranged from 0.26 to $3.34 \mathrm{mM}$ [129]. The authors also found that the oleate toxicity did not depend upon any of the biological factors (i.e. the origin of the sludge, the specific acetoclastic methanogenic activity or the adaptation of sludge to lipids) but it appeared to be correlated with the specific area of the sludge [129]. This means that sludge with a high specific area such as suspended sludge, will be inhibited to a larger extent than granular sludge.

\section{Pre-treatment}

\subsection{Introduction}

The AD of biosolids was previously shown to be a valuable treatment, resulting in reduction of sludge volume, destruction of pathogenic organisms, a stabilisation of the sludge and production of an energy-rich biogas. However, the application of $\mathrm{AD}$ to biosolids were often limited by very long retention times (20-30 days) and a low overall degradation efficiency of the organic dry solids (30-50\%). Those limiting factors are generally associated with the hydrolysis stage [14]. During hydrolysis, cell walls are ruptured and extracellular polymeric substances (EPS) are degraded resulting in the release of readily available organic material for the acidogenic micro-organisms. This mechanism is particularly important in the digestion of sludge, since the major constituent of its organic fraction are cells, being a relatively unfavourable substrate for microbial degradation [130]. The cell envelope of micro-organisms is a semi-rigid structure which provides sufficient intrinsic strength to protect the cell from osmotic lysis. Microbial cell walls contain glycan strands crosslinked by peptide chains, causing resistance to biodegradation. Several authors, e.g. Refs. [14,130], have indeed identified hydrolysis as the rate-limiting step in $\mathrm{AD}$ of sewage sludge.

Various sludge disintegration methods have hence been studied as a pre-treatment: these methods disrupt cell walls which results in a lysis or disintegration of sludge cells. Slowly degradable, particulate organic material is converted to low molecular weight, readily biodegradable compounds, thus bypassing the rate-limiting hydrolysis stage. Possible pre-treatments include mechanical, thermal, chemical and biological action, as reviewed in the present section with their working mechanism and potential.

The integration of WAS pre-treatment methods in the sludge cycle has already been shown in Fig. 1.

\subsection{Thermal pre-treatment}

The heat treatment of waste-activated sludge (WAS) was shown as early as 1970 [131] to be an effective pre-treatment method for AD. The sludge is generally subjected to temperature in the range $150-200^{\circ} \mathrm{C}$, although lower temperatures have also been reported. The pressures adjoining these temperatures are in the range 600-2500 $\mathrm{kPa}$ [132]. Heat applied during thermal treatment disrupts the chemical bonds of the cell wall and membrane, thus solubilises the cell components. Various authors describe the use of thermal pre-treatment for enhancing AD. Their findings are reported in Table 9.

All studies report a positive impact of thermal pre-treatment on $\mathrm{AD}$. The optimum conditions and magnitude of the improvement, however, vary considerably. This is in line with the findings of Gavala et al. [143] who concluded that temperature and duration of the optimum pre-treatment depend on the nature of the sludge: the greater the proportion of difficulty in hydrolysing biological sludge substances, higher the intensity of pre-treatment needed. In general, thermal pre-treatment of WAS can considerably increase methane production for mesophilic $A D$ and to a lesser extent for thermophilic $A D$, showing that the impact of preconditioning is more significant in a low-rate system such as in a mesophilic digestion. Thermophilic digestion is already more efficient at VSS reduction and methane production as compared

Table 9

Overview of thermal pre-treatment studies

\begin{tabular}{|c|c|c|}
\hline Reference & $\begin{array}{l}\text { Treatment } \\
\text { conditions }\end{array}$ & Comments \\
\hline $\begin{array}{l}\text { Hiraoka et al. } \\
\text { [133] }\end{array}$ & $60-100^{\circ} \mathrm{C}$ & $\begin{array}{l}\text { - Maximum increase in gas production at } \\
60{ }^{\circ} \mathrm{C} \\
\text { - Maximum VS reduction at } 100{ }^{\circ} \mathrm{C} \text { (only } \\
5-10 \% \text { ) }\end{array}$ \\
\hline $\begin{array}{c}\text { Pinnekamp } \\
\text { [134] }\end{array}$ & $120-220^{\circ} \mathrm{C}$ & $\begin{array}{l}\text { - ODS reduction of } 10-55 \% \text { for WAS } \\
\text { - ODS reduction from } 7 \% \text { to } 34 \% \text { for primary } \\
\text { sludge } \\
\text { - Maximum gas yield for treatment } \\
\text { temperature of } 170{ }^{\circ} \mathrm{C} \\
\text { - Positive correlation between gas yield and } \\
\text { treatment temperature }\end{array}$ \\
\hline $\begin{array}{l}\text { Li and Noike } \\
\text { [135] }\end{array}$ & $\begin{array}{l}62-175^{\circ} \mathrm{C} \\
30-60 \mathrm{~min}\end{array}$ & $\begin{array}{l}\text { - Increase of sludge solubilisation ratio by } \\
25-45 \% \text { (optimum at } 90{ }^{\circ} \mathrm{C} \text { ) for WAS } \\
\text { - Increase of } 30 \% \text { VSS degradation and of } \\
100 \% \text { methane production (optimum at } \\
170{ }^{\circ} \mathrm{C} \text { and } 60 \text { min) } \\
\text { - No further improvement for longer } \\
\text { treatment times } \\
\text { - Reduction of retention time in digester by } \\
5 \text { days }\end{array}$ \\
\hline $\begin{array}{l}\text { Tanaka et al. } \\
\text { [136] }\end{array}$ & $\begin{array}{l}180^{\circ} \mathrm{C} \\
60 \mathrm{~min}\end{array}$ & $\begin{array}{l}\text { - } 90 \% \text { increase of methane production } \\
\text { - VSS solubilisation of } 30 \%\end{array}$ \\
\hline $\begin{array}{l}\text { Zheng et al. } \\
\qquad \text { [137] }\end{array}$ & $\begin{array}{l}220^{\circ} \mathrm{C} \\
30 \mathrm{~s}\end{array}$ & $\begin{array}{l}\text { - } 55 \% \text { VS reduction during digestion } \\
\text { Increase in gas production of } 200 \% \text { during } \\
\text { first } 2 \text { days } \\
\text { - Total increase in gas production of } 80 \%\end{array}$ \\
\hline Kim et al. [138] & $\begin{array}{l}121^{\circ} \mathrm{C} \\
30 \mathrm{~min}\end{array}$ & - Increase of VS reduction by $30 \%$ \\
\hline $\begin{array}{l}\text { Valo et al. } \\
\text { [139] }\end{array}$ & $\begin{array}{l}170^{\circ} \mathrm{C} \\
15 \mathrm{~min}\end{array}$ & $\begin{array}{l}\text { - } 59 \% \text { increase of TS reduction } \\
\text { - } 92 \% \text { higher gas production }\end{array}$ \\
\hline $\begin{array}{l}\text { Ferrer et al. } \\
\qquad[140]\end{array}$ & $\begin{array}{l}70{ }^{\circ} \mathrm{C} \\
9-72 \mathrm{~h}\end{array}$ & $\begin{array}{l}\text { - Studied thermophilic digestion } \\
\text { - Positive effect on gas production } \\
\text { - Higher temperature }\left(110-134^{\circ} \mathrm{C}\right) \text { did not } \\
\text { have any effect }\end{array}$ \\
\hline $\begin{array}{l}\text { Climent et al. } \\
\text { [141] }\end{array}$ & $\begin{array}{l}70-134{ }^{\circ} \mathrm{C} \\
90 \mathrm{~min}-9 \mathrm{~h}\end{array}$ & $\begin{array}{l}\text { - Studied thermophilic digestion } \\
\text { - } 50 \% \text { increase of biogas production at } 70{ }^{\circ} \mathrm{C} \\
(9 \mathrm{~h}) \\
\text { - No effect for high-temperature treatment }\end{array}$ \\
\hline $\begin{array}{l}\text { Bougrier et al. } \\
\text { [142] }\end{array}$ & $135-190^{\circ} \mathrm{C}$ & $\begin{array}{l}\text { - Increased methane production by } 25 \% \text { at } \\
\text { the } 190{ }^{\circ} \mathrm{C} \text { treatment }\end{array}$ \\
\hline
\end{tabular}


with mesophilic digestion, and reduced benefits of pre-treatment can be expected.

Some commercial processes were developed based on thermal pre-treatments. The Norwegian company Cambi developed a system based on thermal hydrolysis [144]. A solids solubilisation of approximately $30 \%$ was reported (dependant on the type of sludge being processes) for a $30 \mathrm{~min}$ treatment at $180^{\circ} \mathrm{C}$. An associated increase of biogas production by $150 \%$ is reported by the company. A similar thermal treatment is sold as BioThelys ${ }^{\circledR}$ by Krüger Inc., a subsidiary of Veolia Water.

Evidently, the thermal pre-treatment requires the input of a considerable amount of heat, since the sludge feedstock needs to be preheated to the operating temperature $\left(\sim 700 \mathrm{~kJ} / \mathrm{m}^{3}\right)$ at the expense of using some of the biogas produced.

\subsection{Mechanical pre-treatment}

Mechanical treatment employs several strategies for physically disintegrating the cells and partly solubilising their content.

The use of a colloid mill (with stationary and rotating disc) for disrupting microbial cells was first reported by Harrison [145]. The heating of the suspension by energy dissipation can moreover enhance the disintegration. The same paper also describes the use of a high-speed shaker ball mill for sludge disintegration. In the treatment reactor, moving impellers transfer kinetic energy to grinding glass beads thereby creating high shear stresses that break the cell walls. Alternative ball mills using ceramic or steel beads were also reported. The use on an agitator ball mill was studied by Kunz et al. [146]. Sludge was pressed through a cylindrical or conical space by an agitator inducing shear stresses of sufficient magnitude to break the bacterial cell walls.

One of the most frequently used methods for large-scale operation is high-pressure homogenisation, compressing the sludge to $60 \mathrm{MPa}[145,147]$. The compressed suspension is then depressurised through a valve and projected at high speed against an impaction ring. The cells are hereby subjected to turbulence, cavitation and shear stresses, resulting in cell disintegration.

Some studies reporting the effects of these mechanical methods on AD are summarised in Table 10.

Although less results are available than for the other pretreatment methods, it is seen that their efficiency of improving AD of sewage sludge is rather low, compared to the other methods. Although most techniques consume a lot of power [130], they do not require the addition of chemicals or heat.

\subsection{Chemical pre-treatment}

Chemical pre-treatment to enhance the AD treats the sludge to hydrolyse the cell wall and membrane and thus increase the solubility of the organic matter contained within the cells. Various chemical methods have been developed, based on different operating principles. The major groups are (i) acid and alkaline (thermal) hydrolysis, (ii) ozonation, and (iii) advanced oxidation methods. These methods are described hereafter.

\subsubsection{Acid and alkaline (thermal) hydrolysis}

In (thermo)chemical hydrolysis methods, an acid or base is added to solubilise the sludge. The addition of acid or base avoids the necessity of high temperatures and these methods are thus mostly carried out at ambient or moderate temperatures. An overview of these methods is presented in Neyens and Baeyens [153]. Some experimental results are given in Table 11. The methods are shown to be an effective albeit cumbersome method for sludge solubilisation since required $\mathrm{pH}$ levels are extreme, and sludge needs subsequently to be re-neutralised. Their use as a pretreatment for $\mathrm{AD}$ is hence rather limited.

\subsubsection{Oxidative sludge pre-treatment}

Oxidative waste sludge destruction was first practised in the aerobic Zimpro process originally designed as a wet oxidation method in the USA (1954). This process uses oxygen or air at high temperatures $\left(260^{\circ} \mathrm{C}\right)$ and pressures (10 MPa) [159]. An effective solubilisation of a large part of the sludge was achieved. Problems

\section{Table 11}

Overview of acid and alkaline thermal hydrolysis pre-treatment studies

\begin{tabular}{|c|c|c|}
\hline Reference & Used chemicals & Comments \\
\hline $\begin{array}{l}\text { Knezevic et al. } \\
{[154]}\end{array}$ & $\mathrm{NaOH}$ & $\begin{array}{l}\text { - No significant improvement in } \\
\text { VSS reduction } \\
\text { - Improved gas production with } \\
\text { increased } \mathrm{NaOH} \text { dosage }\end{array}$ \\
\hline Tanaka et al. [155] & $\begin{array}{l}\mathrm{NaOH} \\
130{ }^{\circ} \mathrm{C}\end{array}$ & $\begin{array}{l}\text { - Increase of biogas production } \\
\text { by } 20 \% \\
\text { - Improvement of methane } \\
\text { production of } 50 \%\end{array}$ \\
\hline Inagaki et al. [156] & $\mathrm{NaOH}$ & $\begin{array}{l}\text { - Improvement of digestion by } \\
60 \%\end{array}$ \\
\hline $\begin{array}{l}\text { Tanaka and } \\
\text { Kamiyama } \\
\text { [157] }\end{array}$ & $\mathrm{NaOH}$ & $\begin{array}{l}\text { - } 60 \% \text { increase of overall SS } \\
\text { reduction }\end{array}$ \\
\hline Kim et al. [138] & $\begin{array}{l}130^{\circ} \mathrm{C} \\
\mathrm{NaOH}, \mathrm{KOH} \\
\mathrm{Mg}(\mathrm{OH})_{2}, \mathrm{Ca}(\mathrm{OH})_{2}\end{array}$ & $\begin{array}{l}\text { - Increase of VS reduction by } \\
30 \%\end{array}$ \\
\hline $\begin{array}{l}\text { Carballa et al. } \\
\text { [158] }\end{array}$ & $\mathrm{CaO}$ & $\begin{array}{l}\text { - No significant improvement of } \\
\text { anaerobic digestion }\end{array}$ \\
\hline
\end{tabular}

Table 10

Overview of mechanical pre-treatment studies

\begin{tabular}{|c|c|c|}
\hline Reference & Method & Comments \\
\hline Rivard and Nagle [148] & Shear treatment & - Increase of TSS degradation by $90 \%$ \\
\hline Choi et al. [149] & Mechanical jet (5-50 bar) & $\begin{array}{l}\text { - Increase of soluble protein concentration up to } 86 \% \text { ( } 50 \text { bar) } \\
\text { - Increase of VSS removal with } 50 \%\end{array}$ \\
\hline Baier and Schmidheiny [150] & Ball mill and cutting mill & $\begin{array}{l}\text { - Increase of } 19 \% \text { in VS degradation } \\
\text { - Ball diameter, speed, ball material and sludge concentration are important parameters }\end{array}$ \\
\hline Kopp et al. [151] & $\begin{array}{l}\text { Stirred ball mill, high-pressure } \\
\text { homogenisation, shear gap } \\
\text { homogenisation }\end{array}$ & $\begin{array}{l}\text { - Enhancement of biodegradation especially for short times (increase of } 100 \% \text { after } 2 \text { days) } \\
\text { - Improvement of about } 20 \% \text { after } 4 \text { days }\end{array}$ \\
\hline Nah et al. [152] & Mechanical jet (30 bar) & - Increase of TSS removal efficiency by $50 \%$ \\
\hline
\end{tabular}


Table 12

Overview of ozonation pre-treatment studies

\begin{tabular}{ll}
\hline Reference & Comments \\
\hline Weemaes et al. [162] & $\begin{array}{l}\text { - Increase of methane production up to } 112 \% \\
\text { - Increase of COD degradation up to } 64 \%\end{array}$ \\
Battimelli et al. [163] & - Increase of SS removal by $22 \%$ \\
Goel et al. [164] & - Increase in TS destruction by $28 \%$ \\
\hline
\end{tabular}

with odour, corrosion and high energy cost however restrict the practical applications of this process. A modern method using wet oxidation is the Vertech process, achieving $20 \%$ solubilisation and $75 \%$ complete oxidation [160].

In the nineties, the Cambi process combined thermal hydrolysis with $\mathrm{AD}$ to produce a safe, storable and stable product [161].

The most frequent studies oxidative methods are ozonation and peroxidation, belonging to the advanced oxidation processes and based on the generation of hydroxyl $\left(\mathrm{OH}^{*}\right)$ radicals which are extremely powerful oxidants (oxidation potential $2.8 \mathrm{~V}$ ). Due to the oxidative power, hazardous by-products were not detected [162].

Ozone $\left(\mathrm{O}_{3}\right)$ is a powerful oxidant which is commonly used for the disinfection of drinking water and the destruction of pathogens. The treatment can also be applied to the destruction of cellular material in WAS. The results of some previous studies are reported in Table 12 .

These radicals are frequently generated using hydrogen peroxide $\mathrm{H}_{2} \mathrm{O}_{2}$ in combination with transition metal salts. Generally, $\mathrm{Fe}^{2+}$-ions are used in combination with $\mathrm{H}_{2} \mathrm{O}_{2}$. This reaction is referred to as the Fenton peroxidation. A major drawback of this method is the necessity of bringing the sludge to a very low $\mathrm{pH}$ (optimum at 3 ). For a complete review of the chemistry behind this process, the reader is referred to Neyens and Baeyens [165]. Its application in sludge treatment was studied by Neyens et al. [166,167]. More recent research uses alternative peroxidants such as peroxymonosulphate POMS and dimethyldioxirane (DMDO) which do not require stringent reaction conditions and significantly increase the biogas production during the anaerobic treatment of raw secondary sludge [165]. Additional tests are currently carried out using thickened sludge. Although oxidative treatments are considered promising, additional research is needed to avoid extreme reaction conditions in terms of pressures and temperatures, or $\mathrm{pH}$ (Fenton). Advantages, drawbacks and economics have been described by Neyens et al. [165-168].

\subsection{Ultrasound}

Sonication is no doubt the most powerful method to disrupt sludge cells. Although cell disintegrations of $100 \%$ can be obtained at high power levels, power consumption then becomes a serious drawback [130]. The principle of ultrasonic treatment relies on the induced cavitation process. Through subsequent compression and expansion of the fluid under the effect of the ultrasonic waves, implosions are generated which give rise to local extreme conditions (temperatures of several thousands degrees centigrade and pressures of up to 500 bar). The nature of cavitation and the application of ultrasound in sludge treatment is reviewed by Dewil et al. [169]. Other references to its use as pre-treatment for $\mathrm{AD}$ are given in Table 13.

Ultrasound treatment units are commercially available in a wide range of capacities (between 1 and $20 \mathrm{~kW}$ ) and modular layout. Capital costs today are roughly $€ 20,000 / \mathrm{kW}$, with $1 \mathrm{~kW}$
Table 13

Overview of ultrasonic pre-treatment studies

\begin{tabular}{|c|c|}
\hline Reference & Comments \\
\hline Shimizu et al. [170] & Increased solubilisation ratio up to $80 \%$ \\
\hline Wang et al. [13] & $\begin{array}{l}\text { Enhancement of digestion by } 46 \% \text { for a } 40 \text {-min } \\
\text { treatment at } 200 \mathrm{~W}\end{array}$ \\
\hline Neis et al. [171] & $\begin{array}{l}\text { Enhancement of anaerobic digestion by } 42.4 \% \text { at } \\
\text { intensity of } 18 \mathrm{~W} / \mathrm{cm}^{2}\end{array}$ \\
\hline
\end{tabular}

capable of treating sludge from a WWTP of 10,000 p.e. Operation and maintenance costs are minimal although the ultrasound probes need replacement every $1.5-2$ years.

The use of ultrasound enhancement has been tested in several WWTP, ranging from 50,000 to 750,000 p.e. (for a total of nearly 1.5 Mp.e.). Improved VS destruction ranged from $40 \%$ to $55 \%$, enhancing the biogas production by about $50 \%$. Improvements were also found in the dewatering plants, where cake dryness increased by $5 \%$ in spite of using $33 \%$ less polymer.

Savings are approximately $€ 1.5-2 /$ p.e./year. Since the degradation rate is accelerated, the dimensions of the digesters can moreover be reduced for a given load, thus reducing the impact of high capital requirements. A recent paper by Appels et al. [172] describes the principles, application and tentative economics.

\subsection{Bacterial and enzyme hydrolysis}

Recently, tests have been conducted on the effect of adding specific strains of bacteria to the sludge being anaerobically digested. Although literature is still scarce on the subject, with major sewage treatment companies not willing to divulge results, the onset of the research was given by Miah et al. [173] who measured a $210 \%$ enhanced biogas production during thermophilic digestion (at $65^{\circ} \mathrm{C}$ ) caused by the protease activity of the Geobacillus sp. strain AT1.

Biological hydrolysis with or without enzyme addition relies on the enzymatic lysis to crack the cell-wall compounds by an enzyme catalysed reaction. Analytic processes can be used at ambient temperatures or external enzyme can be added $[174,175]$.

\section{Biogas enrichment, compression and storage}

\subsection{Perspectives}

As produced by digestion, biogas is a clean and environmentally friendly fuel, although it contains only about 55-65\% of $\mathrm{CH}_{4}$. Other constituents include $30-40 \%$ of $\mathrm{CO}_{2}$, fractions of water vapour, traces of $\mathrm{H}_{2} \mathrm{~S}$ and $\mathrm{H}_{2}$, and possibly other contaminants (e.g. siloxanes).

Without further treatment, it can only be used at the place of production. There is a great need to increase the energy content of the biogas, thus making it transportable over larger distances if economically and energy sensible. Ultimately, the compression and use of gas cylinders or introduction into the gas network are targets. This enrichment and enhanced potential of use, can only be achieved after removing the $\mathrm{CO}_{2}$ and contaminants. A typical composition of biogas from sewage sludge $\mathrm{AD}$ or landfill capture and natural gas (NG) are shown in Table 14.

The heating value of biogas is determined by the $\mathrm{CH}_{4}$ content, with the higher heating value being the energy released when $1 \mathrm{~N} \mathrm{~m}^{3}$ of biogas is combusted and the water vapour formed within combustion is condensed. The lower heating value omits the vapour condensation. 
Table 14

Composition and parameters from different gas sources [176]

\begin{tabular}{|c|c|c|c|c|c|}
\hline Parameter & Unit & Landfill gas & Digestion biogas & North Sea NG & Dutch NG \\
\hline \multirow[t]{3}{*}{ Lower heating value } & $\mathrm{MJ} / \mathrm{N} \mathrm{m}^{3}$ & 16 & 23 & 40 & 31.6 \\
\hline & $\mathrm{KWh} / \mathrm{N} \mathrm{m}^{3}$ & 4.4 & 6.5 & 11 & 8.8 \\
\hline & $\mathrm{MJ} / \mathrm{kg}$ & 12.3 & 20.2 & 47 & 38 \\
\hline Density & $\mathrm{kg} / \mathrm{N} \mathrm{m}^{3}$ & 1.3 & 1.2 & 0.84 & 0.8 \\
\hline Methane number & & $>130$ & $>135$ & 70 & - \\
\hline Methane (and variation) & vol\% & $45(30-65)$ & $63(53-70)$ & $87(-)$ & $81(-)$ \\
\hline Higher hydrocarbons & vol\% & 0 & 0 & 12 & 3.5 \\
\hline Hydrogen & vol\% & $0-3$ & 0 & 0 & - \\
\hline Carbon monoxide & vol\% & 0 & 0 & 0 & 0 \\
\hline Carbon dioxide (and variation) & vol\% & $40(15-50)$ & $47(30-50)$ & $1.2(-)$ & $1(-)$ \\
\hline Nitrogen (and variation) & vol\% & $15(5-40)$ & $0.2(-)$ & $0.3(-)$ & $14(-)$ \\
\hline Oxygen (and variation) & vol\% & $1(0-5)$ & $0(-)$ & $0(-)$ & $0(-)$ \\
\hline Hydrogen sulphide (and variation) & ppm & $<100(0-500)$ & $<1000\left(0-10^{4}\right)$ & $1.5(1-2)$ & $-(-)$ \\
\hline Ammonia & ppm & 5 & $<100$ & 0 & - \\
\hline Total chlorine (as $\mathrm{Cl}^{-}$) & $\mathrm{mg} / \mathrm{N} \mathrm{m}^{3}$ & $20-200$ & $0-5$ & 0 & - \\
\hline
\end{tabular}

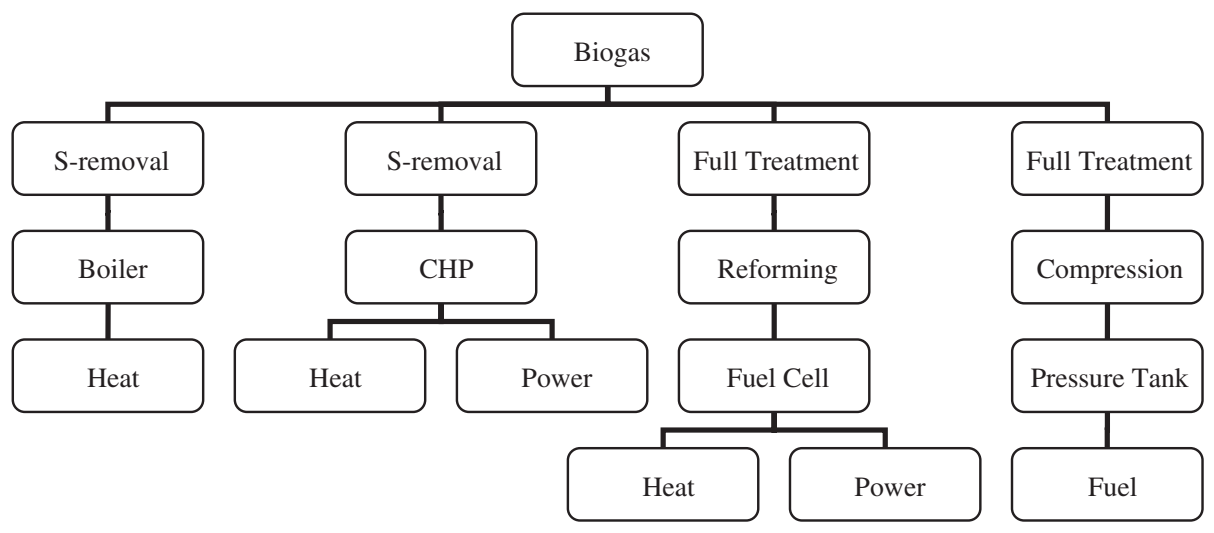

Fig. 8. Biogas utilisation and required upgrading.

The methane number describes the gas resistance to knocking when used in a combustion engine. Methane has per definition a methane number of 100 and $\mathrm{H}_{2}$ a methane number of $0 . \mathrm{CO}_{2}$ increases the methane number because it is a non-combustible gas with a high knocking resistance. Upgraded biogas, therefore, has a methane number in excess of 100 .

Biogas contains a variety of sulphur compounds, mostly sulphides, although traces of disulphides and thiols are also detected. Especially oxidised sulphur (sulphate and sulphite) is corrosive with the presence of $\mathrm{H}_{2} \mathrm{O} . \mathrm{H}_{2} \mathrm{~S}$ itself is reactive with most metals and the reactivity is enhanced by concentration and pressure, by the presence of $\mathrm{H}_{2} \mathrm{O}$ and at elevated temperature.

Halogenated compounds are often present in landfill gas, but rarely in biogas from digestion of sewage sludge since, if present, they would have killed off the digester in the first place. Siloxanes are volatile compounds of silicium bound by organic radicals. The amount of silicium has to be reduced to a minimum, especially in engine applications.

High concentrations of ammonia are a problem for gas engines, and normally $100 \mathrm{mg} / \mathrm{N} \mathrm{m}^{3} \mathrm{NH}_{3}$ can be accepted. The combustion, however, leads to $\mathrm{NO}_{x}$ formation.

All biogas plants must be equipped with some kind of filter to reduce the amount of fine particles in the gas. These filters, with a $2-5 \mu \mathrm{m}$ mesh size, not only remove particulates, but also reduce the content of droplets of water or foam.

\subsection{Biogas utilisation}

Gas is an excellent fuel for a large number of applications and can ultimately also be used as feedstock for the production of chemicals. Biogas can more or less be used in all applications that were developed for natural gas.

There are four basic ways of biogas utilisation, production of heat and steam, electricity generation/co-generation, use as vehicle fuel, and (possibly) production of chemicals.

These utilisations are governed by national frameworks like the tax system, subsidies, green energy certificates and increased feed-in tariffs for electricity, availability of heat or gas grids.

Worldwide, biogas is mainly used in combined heat and power (CHP) applications, whereas various EU countries have embarked on programmes to use a growing portion of the biogas in the transport sector, especially attractive in view of the steady increase of the cost of fossil fuels. The various utilisation pathways are illustrated in Fig. 8.

Conventional gas burners can easily be adjusted to biogas by changing the air-to-gas ratio. Burning biogas is an established and reliable technology, with low demands on biogas quality. Pressure usually has to be between 8 and 25 mbar. It is recommended to reduce the level of $\mathrm{H}_{2} \mathrm{~S}$ below $1000 \mathrm{ppm}$ to maintain the dew point at approximately $150{ }^{\circ} \mathrm{C}$.

Biogas is also the ideal fuel for CHP applications. Although gas turbines could be used (micro-turbines, $25-100 \mathrm{~kW}$; large turbines, $>100 \mathrm{~kW}$ ) with low emissions, efficiencies comparable to sparkignition engines and low maintenance, the investments are on the high side. Mostly internal combustion engines are used in CHP applications, either as spark-ignition or dual fuel engines. Dual fuel engines, with, e.g. injection of diesel $(\geqslant 10 \%)$ are, although much less economic, very popular in smaller scales, with good power efficiency (up to 40\%). They have high emissions, unless a treatment of combustion gas is used, but allow easy start-up by using diesel only (when the biogas production is started). 
Spark-ignition engines can be stoichiometric or lean-burn engines, the latter common for larger sizes and having a higher efficiency.

Fuel cells are considered to become the small-scale power plant of the future, having the potential to reach very high efficiencies ( $>60 \%$ ) and low emissions. Special interest for biogas is focussed on hot fuel cells $\left(>800^{\circ} \mathrm{C}\right)$ where $\mathrm{CO}_{2}$ does not inhibit the electrochemical process, but rather serves as a heat carrier. Either the solid oxide fuel cell, for small applications of a few $\mathrm{kW}$, or the molten carbonate fuel cells (up to $250 \mathrm{~kW}$ and more) can be envisaged.

Gas vehicles can use biogas as fuel [177], provided it is upgraded to natural gas quality, and application in the same vehicles that use natural gas (NGVs) becomes possible. At the end of 2005 there were more than 5 million NGVs in the world. The number of public transport vehicles driven on gas such as buses and waste trucks is increasing considerably. Most of the gas driven personal cars are converted vehicles that have been retro-fitted with a gas tank in the luggage compartment and a gas supply system in addition to the normal petrol fuel system. Dedicated gas vehicles run at a better efficiency and also allow for more convenient placement of the gas cylinders without losing luggage space. Gas is stored at 200-250 bar in pressure vessels made from steel or aluminium composite materials. Today more than 50 manufacturers worldwide offer a range of 250 models of commuter, light and heavy duty vehicles. Gas vehicles have substantial advantages over vehicles equipped with diesel or petrol engines, since $\mathrm{CO}_{2}$ emissions are reduced by more than 95\%. Emissions of particles and soot are also drastically reduced. Heavy duty vehicles are normally converted to run on methane gas only, but in some cases dual fuel engines can also be used. The dual fuel engine still has the original diesel injection system and gas is ignited by injection of a small amount of diesel oil. Dual fuel engines normally require less engine development and maintain the same driveability as a diesel vehicle. However, emission values are not as good as for the corresponding dedicated gas vehicle and the engine technology remains a compromise between spark ignition and diesel engine. Beside the close to $100 \% \mathrm{CO}_{2}$ reduction, pure gas engines with catalytic converters demonstrate far better emission values than the most modern diesel engines (EURO 4 and 5) tested according to the European Transient Cycle (ETC) or the Enhanced Environmental friendly Vehicle (EEV) standard at the EMPA, Switzerland. Stoichiometric gas engines with an air-to-fuel ratio of 1 demonstrate a better emission pattern than lean engines. However, both are far better than dual fuel engines although at a reduced efficiency.

The number of biogas and natural gas filling stations is still insufficient in Europe and elsewhere in the world, although the situation is improving enormously with the number of pumping stations multiplied over the last few years: at the end of 2005 there were 1600 pumping stations in Europe. By the end of 2006 Germany had 1000 stations in operation, Switzerland 100 and Austria more than 50 .

Biogas injection in the gas grid is possible, and various countries of the EU have proposed standards for injecting upgraded biogas into the grid to avoid contamination of the grid. These standards of, e.g. Sweden, Switzerland, Germany and France, fix limits for, e.g. sulphur, oxygen, particles and dew point. Upgrading methods must allow treated biogas to meet these stringent quality standards. This upgrading and associated cost outweigh the rising costs of fossil fuels.

\subsection{Biogas upgrading technologies}

The major reasons for gas upgrading include the need to fulfil the requirements of gas appliances (engines, boilers, fuel cells, vehicles, etc.); to increase the heating value of the biogas; and/or to standardise the biogas quality. The required quality depends strongly on the application, as shown in Table 15.

\subsubsection{Carbon dioxide removal}

Removing $\mathrm{CO}_{2}$ increases the heating value and leads to a consistent gas quality, similar to natural gas. When using removal techniques, it is important to keep methane losses low for economical and environmental reasons since $\mathrm{CH}_{4}$ is a greenhouse gas 21 times stronger than $\mathrm{CO}_{2}$ [178].

There are different methods of removal, most commonly performed as absorption or adsorption. Cryogenic separation would also be possible, albeit expensive. Membrane separation gains interest [179].

In absorption processes, $\mathrm{CO}_{2}$ and $\mathrm{H}_{2} \mathrm{~S}$ are simultaneously removed due to the difference in binding forces of the polar $\mathrm{CO}_{2}$ and $\mathrm{H}_{2} \mathrm{~S}$ and the non-polar $\mathrm{CH}_{4}$. Water is the most common solvent for counter-current scrubbing of pre-compressed biogas (4-7 bar). The design of a water scrubbing system depends on the solubility of $\mathrm{CO}_{2}$, as solubility is governed by pressure, temperature and $\mathrm{pH}$ as given in Table 16: as the pressure increases, the solubility of $\mathrm{CO}_{2}$ in water increases; but decreases as the temperature increases.

After pressure scrubbing, $\mathrm{CO}_{2}$ and $\mathrm{H}_{2} \mathrm{~S}$ are released in a flash tank, where the pressure is reduced and the temperature possibly increased. $\mathrm{H}_{2} \mathrm{~S}$, which is released to the air can create an emission problem. Some of the sulphur accumulates in the water and can cause problems of fouling or corrosion of piping. It is hence recommended to separate $\mathrm{H}_{2} \mathrm{~S}$ beforehand. Air or vacuum stripping are seldom used since introducing $\mathrm{O}_{2}$ in the system. Results show that $5-10 \%$ of $\mathrm{CO}_{2}$ remains in the biogas.

Of course, absorption can be nearly complete if $\mathrm{Ca}(\mathrm{OH})_{2}$ solutions are used to remove both $\mathrm{CO}_{2}$ and $\mathrm{H}_{2} \mathrm{~S}$, resulting in the formation of insoluble $\mathrm{CaCO}_{3}$ and $\mathrm{CaS}$.

Organic solvents such as polyethyleneglycol (Selexol ${ }^{\circledR}$, Genosorb $^{\mathbb{R}}$ ) and alkanol amines (mono-ethanol-amine, or di-ethanolamine) can be used to dissolve $\mathrm{CO}_{2}$ and $\mathrm{H}_{2} \mathrm{~S}$, which are more soluble than $\mathrm{CH}_{4}$ in these liquids, and low-pressure operation is possible. The chemical needs to be regenerated with steam. Only small amounts of $\mathrm{CH}_{4}$ are removed. Reductions of $\mathrm{CO}_{2}$ to $0.5-1 \mathrm{vol} \%$ in biogas are possible. The organic solvent removal units are, however, more expensive than those using water as a solvent, and suffer from the need to periodically partly discharge, dispose and replace its solvents.

Table 15

Required removal of biogas components

\begin{tabular}{lllll}
\hline Application & $\mathrm{H}_{2} \mathrm{~S}$ & $\mathrm{CO}_{2}$ & $\mathrm{H}_{2} \mathrm{O}$ & Traces \\
\hline Gas heater (boiler) & $<1000 \mathrm{ppm}$ & $\mathrm{No}$ & No & $\begin{array}{l}\text { Yes (e.g. } \\
\text { siloxanes) }\end{array}$ \\
CHP & $<1000 \mathrm{ppm}$ & No & $\begin{array}{l}\text { Avoid } \\
\text { condensation }\end{array}$ & $\begin{array}{l}\text { Yes (e.g. } \\
\text { siloxanes) } \\
\text { Yes }\end{array}$ \\
Vehicle fuel & Yes & Yes & Yes & Yes \\
Gas grid & Yes & Yes & Yes & \\
\hline
\end{tabular}

Table 16

Approximate solubility of $\mathrm{CO}_{2}$ in water

\begin{tabular}{lllll}
\hline $\begin{array}{l}\text { Pressure } \\
\text { (atmospheric) }\end{array}$ & \multicolumn{4}{l}{ Solubility, in $\mathrm{kg}$ of $\mathrm{CO}_{2}$ per kg of water at different temperatures } \\
\cline { 2 - 5 } & $0^{\circ} \mathrm{C}$ & $10{ }^{\circ} \mathrm{C}$ & $20{ }^{\circ} \mathrm{C}$ & $30{ }^{\circ} \mathrm{C}$ \\
\hline 1 & 0.40 & 0.25 & 0.15 & 0.10 \\
20 & 3.15 & 2.15 & 1.30 & 0.90 \\
50 & 7.70 & 6.95 & 6.00 & 4.80 \\
\hline
\end{tabular}


The removal of $\mathrm{CO}_{2}$ by pressure swing adsorption on solids such as activated carbon or molecular sieves is possible. The selectivity is achieved with different mesh sizes. Various processes are described in the literature [180-182]. Adsorption is generally accomplished at high temperatures and pressure. It is simple in design and easy to operate, but is a costly process with highpressure drops and high heat requirements. Desorption is performed by depressurisation or even by using a slight vacuum. The process needs dry biogas, hence the need to remove the water vapour as pre-treatment step.

Cryogenic separation can be used since $\mathrm{CH}_{4}$ has a boiling point of $-160{ }^{\circ} \mathrm{C}$ at $1 \mathrm{~atm}$, whereas $\mathrm{CO}_{2}$ has a boiling point of $-78^{\circ} \mathrm{C}$. $\mathrm{CO}_{2}$ can be removed as liquid by cooling the biogas mixture at elevated pressure. Until now, this expensive method has only been tested in pilot plants in Europe and in the USA. More than 97\% pure $\mathrm{CH}_{4}$ is produced. Investment and operational costs are high and limit its current application [9].

Membrane separation gains interest [179,183-187]. Some components of the raw gas can be transported through a thin membrane while others are retained. The transportation of each component is driven by the difference in partial pressure over the membrane and is highly dependent on the permeability of the component in the membrane material [179,188]. For high methane purity, permeability must be high. Solid membranes constructed from acetate-cellulose polymer have permeabilities for $\mathrm{CO}_{2}$ and $\mathrm{H}_{2} \mathrm{~S}$ up to 20 and 60 times the value for $\mathrm{CH}_{4}$. However, high pressures (up to 25 bar) are required for the process. Although the gas flux across the membrane increases proportionately with the pressure difference, thus reduces the size of the membrane, there is a maximum pressure which the membrane can withstand. Since some $\mathrm{CH}_{4}$ passes through the membrane to the permeate stream, methane losses occur. If the permeate can be used in a CHP (combined with raw gas), these $\mathrm{CH}_{4}$ loss can be recovered.

Additional techniques are under investigation such as the chemical conversion by e.g. catalytically reacting $\mathrm{CO}_{2}$ and $\mathrm{H}_{2}$ to $\mathrm{CH}_{4}$ [189]. This process is extremely expensive and the need of $\mathrm{H}_{2}$ makes the process generally unsuitable. In-situ $\mathrm{CH}_{4}$ enrichment is under development [176]. Sludge from the digestion chamber is counter currently contacted by air. Carbon dioxide that is dissolved in the sludge is desorbed. The $\mathrm{CO}_{2}$-lean sludge is led back to the digestion chamber where more carbon dioxide can now dissolve into the sludge, resulting in $\mathrm{CH}_{4}$ enriched gas in the chamber. The results from lab scale test in Sweden indicate that it is technically possible to construct a system that increases the methane content of the gas to $95 \%$ and still keeps the methane losses below $2 \%$ [176].

\subsubsection{Removal of water}

Biogas is saturated with water vapour when it leaves the digester. Drying is generally needed or recommended. Refrigeration or sensible pipework design is a common method to condense the water. In order to reach higher dew points, the gas can be compressed before cooling.

Adsorption on silica gel or $\mathrm{Al}_{2} \mathrm{O}_{3}$ is applied when very low dew points need to be achieved. An alternative method of drying biogas can be the absorption in glycol or hygroscopic salts, which can be recovered at elevated temperatures.

\subsubsection{Removal of $\mathrm{H}_{2} \mathrm{~S}$}

It should be remembered that appropriate conditioning of the sludge can limit the $\mathrm{H}_{2} \mathrm{~S}$ content present in the biogas [190]. The addition of $\mathrm{Fe}^{3+}$-salts to the sludge can indeed produce insoluble sulphides and reduce the free $\mathrm{H}_{2} \mathrm{~S}$ in the biogas to less than $150 \mathrm{ppm}$ (depending on the amount of $\mathrm{Fe}^{3+}$ added). An excess of $\mathrm{Fe}^{3+}$ salts added can however inhibit the biogas formation.

$\mathrm{H}_{2} \mathrm{~S}$ can also be adsorbed on activated carbon [191]. Activated carbon acts as a catalyst to convert $\mathrm{H}_{2} \mathrm{~S}$ into elemental $\mathrm{S}$. Impregnation with $\mathrm{KI}$ is needed. Impregnated-activated carbon is a common method of removal of $\mathrm{H}_{2} \mathrm{~S}$ before upgrading with PSA.

Micro-organisms, belonging to the Thiobacillus family, can be used to reduce the level of sulphides in biogas, by oxidising it mainly to elementary sulphur and some sulphates. These bacteria are commonly present in the digestion material and thus do not have to be inoculated. Furthermore, most of them are autotrophic, which means that they use carbon dioxide from the biogas as carbon source. Oxygen needs to be added to the biogas for biological desulphurisation and the level needed depends on the concentration of hydrogen sulphide, usually around 2-6 vol\% air in biogas. The simplest method for desulphurisation is to add oxygen or air directly into the digestion chamber. With this method, $\mathrm{H}_{2} \mathrm{~S}$ level can be reduced by up to $95 \%$ to levels less than $50 \mathrm{ppm}$, however function of temperature, place and amount of air added and reaction time. When adding air into the biogas, safety measures need to be taken into consideration to avoid overdosing of air in case of a pump failure. Methane is explosive in the range 5-15\% in air. Biological desulphurisation can also take place in a separate bio-filter filled with plastic bodies on which desulphurising micro-organisms are attached. In the unit up-flowing biogas meets a counter flow of liquid consisting of gas condensate and liquid from effluent slurry separation or a solution of minerals. Before the biogas enters the unit, $5-10$ vol\% air is added. The $\mathrm{H}_{2} \mathrm{~S}$ level can be reduced from $3000-5000 \mathrm{ppm}$ to $50-100 \mathrm{ppm}$. Ammonia is separated at the same time [192].

$\mathrm{H}_{2} \mathrm{~S}$ can also be reduced by $\mathrm{NaOH}$ scrubbing to form $\mathrm{Na}_{2} \mathrm{~S}$ of NaHS, both unsoluble salts.

\subsubsection{Removal of trace gases}

It was already mentioned that siloxanes can be present in the biogas. The reduction of their concentration and/or abatement processes were described in detail by Dewil et al. [193].

The presence of siloxanes in biogas gives rise to some problems regarding its thermal valorisation [193]. These silicon-containing compounds are widely used in various industrial processes (e.g. for replacing organic solvents) and are frequently added to consumer products (e.g. detergents, personal care products, etc.). Moreover they are released as a residue in the production of silicon-containing chemicals. The consumption of siloxanes is growing steadily, e.g. wet wipes, disposable nappies, etc. A significant amount of siloxanes reaches the wastewater and are not decomposed in a conventional-activated sludge wastewater treatment plant. Although a large part is volatilised to the atmosphere during the treatment, a significant amount is adsorbed to the sludge flocs.

During the AD of the sludge, siloxanes are released from the sludge and volatilise due to the breakdown of the organic material and the elevated temperature in the digester. Therefore the biogas is enriched with siloxanes. The siloxane concentrations typically found in biogas are between 30 and $50 \mathrm{mg} / \mathrm{m}^{3}$ with peaks up to $400 \mathrm{mg} / \mathrm{m}^{3}$ in some WWTPs [193]. Only volatile siloxanes are detected in the biogas. Schweigkofler and Niessner [194] reported that a only two cyclic siloxanes, i.e. octamethylcyclotetrasiloxane (D4) and decamethylcyclopentasiloxane (D5), are detected in significant amounts.

During the combustion of the biogas, these siloxanes are converted into a hard and abrasive microcrystalline silica which 


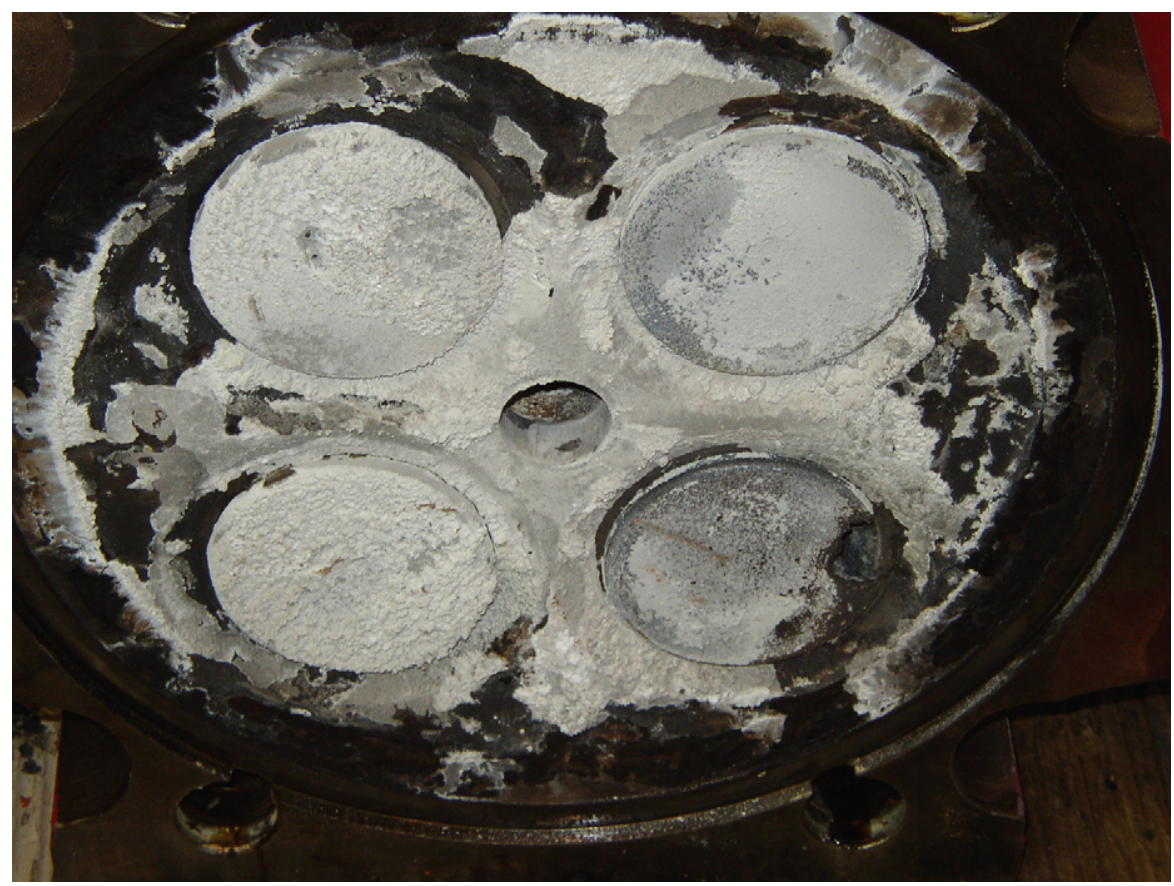

Fig. 9. Fouling of engine pistons by silica.

gradually coats the gas beneficiation equipment. The coating leads to serious motor damage by abrasion of gas motor surfaces, the overheating of sensitive motor parts (thermal insulator) and by depressing the function of spark plugs. Moreover, the catalytic gas exhaust treatment is affected [195]. The crystalline sand moreover accumulates in lubricant oil and coats turbine surfaces. For the biogas of Trecatti (UK), the presence of up to $400 \mathrm{mg} / \mathrm{m}^{3}$ of volatile siloxanes led to a major engine failure within $200 \mathrm{~h}$ of operation [196]. The problem is moreover enhanced by the use of efficient spark-ignition engines which are fast running, operate at high temperature and use biogas only. Previous dual fuel engines (slow, low temperature, with fuel oil to aid ignition) were less prone to silica deposits. Illustration of the silica fouling on the pistons of an engine is shown in Fig. 9.

Although it is difficult to measure the concentration of siloxanes in sludge and biogas, a recent testing of analytical methods revealed that extraction followed by GC-MS was an adequate method [197].

All the currently used treatment techniques are end-of-pipe and remove siloxanes from the biogas. The most frequently used method for removing siloxanes is the adsorption on activated carbon. Since biogas contains a broad range of compounds $\left(\mathrm{H}_{2} \mathrm{~S}\right.$, siloxanes, organics) with concentrations covering several orders of magnitude, a competitive adsorption of siloxanes and a variety of trace compounds must be considered leading to large adsorption capacities needed for the target silicon compounds when using adsorbent materials in biogas pretreatment [194]. Active sites of the adsorbent will retain water vapour and other pollutants, thus decreasing adsorbent life [198]. Moreover the adsorbent beds have to be replaced regularly because siloxanes are difficult to desorb from the material. At Trecatti (UK) for example, a weekly change of activated carbon is necessary, with a 1-day downtime at the adsorber and a cost of nearly $€ 2000$ per change.

Other possible adsorbents are molecular sieves and polymer pellets. Schweigkofler and Niessner [194] made a comparative study of adsorption materials using polymer beads, silica gel and activated carbon, which all exhibited large adsorption capacities for the siloxane D5. Especially silica gel seemed to be promising and a highly cost-effective candidate, since this can be used simultaneously for biogas drying.

Absorption in non-volatile organic solvents has also been reported in both spray and packed columns (e.g. with Raschig rings). A major drawback of this gas pre-treatment method is the fact that complete siloxane elimination is difficult to obtain since the highly volatile siloxanes are easily stripped from the solvent at elevated gas flow rates. This problem does not arise if the siloxanes are chemically absorbed, i.e. they are converted to compounds of low volatility [194].

The cryogenic condensation of the siloxanes from the gas is a feasible, but an expensive alternative. When the temperature of the biogas is decreased, a condensate is formed which contains part of the siloxanes that are present. Schweigkofler and Niessner [194] studied the removal efficiency when the biogas was cooled to $5^{\circ} \mathrm{C}$. Over $88 \%$ of the initial siloxane concentrations were still present in both landfill and digester gas. Hagmann et al. [195] reported a cleanup efficiency for a range of volatile siloxanes of $25.9 \%$ when cooling to $-25^{\circ} \mathrm{C}$, and of $99.3 \%$ when freezing to $-70{ }^{\circ} \mathrm{C}$.

A final reported method for removing siloxanes from biogas is chemical abatement. The caustic- or acidic-catalysed hydrolysis of the silicon-oxygen bond seems to be useful. The high stability of these compounds, however, requires high or low $\mathrm{pH}$-values and/or high temperatures [199]. Sulphuric, nitric and phosphoric acid were reported [194] as well as sodium hydroxide [199]. The removal efficiencies of these methods are, however, rather low.

Recently, Appels et al. [200] reported the potential of partly removing siloxanes from the sludge phase by using a peroxidative treatment.

\subsection{Biogas compression and storage}

Compressing the biogas reduces the storage requirements, concentrates the energy content and increases the pressure to a level overcoming pressure drops in subsequent techniques or pipelines. Although various studies have been published [201-204] there is still no large-scale application. In general, the biogas storage options, summarised in Table 17, are presented [205]. 
Table 17

Most commonly used biogas storage options [205]

\begin{tabular}{lll}
\hline Pressure & Storage device & Material \\
\hline Low (0.14-0.41 bar) & Water sealed gas holder & Steel \\
Low & Gas bag & Rubber, plastic, vinyl \\
Medium (1.05-1.97 bar) & Propane or butane tank & Steel \\
High (200 bar) & Commercial gas cylinders & Alloy \\
\hline
\end{tabular}

\section{Operation, maintenance and troubleshooting of digesters}

ADs operate in a stable way if solids levels and the alkalinity/ acid ratio are controlled. They have large inertia, even at 12 days.

The routine operation needs adequate maintenance and repairs, cleaning and start-up/shutdown procedures.

A very detailed account for operations, troubleshooting and control has been published by EPA [206] and summarised by Qasim [7]. The reader is referred to this extensive summary, which deals with: (i) digester start-up, involving the start-up sequence and actions needed to achieve stable digestion condition, (ii) common operational problems and troubleshooting in the event of occurring instabilities such as increases in $\mathrm{CO}_{2}$ or $\mathrm{pH}$, poor supernatant quality and foam, faulty temperature or mixing, consistency of the digester sludge, occurrence of a scum blanket, etc., (iii) routine operation and maintenance with a monitoring programme, a routine maintenance and operator checklist, and (iv) some specifications and descriptions of the main components such as digester cover, mixing and heaters.

\section{Conclusions and recommendations}

$\mathrm{AD}$ is a complex process which requires strict anaerobic conditions to proceed, and depends on the coordinated activity of a complex microbial association to transform organic material into mostly carbon dioxide $\left(\mathrm{CO}_{2}\right)$ and methane $\left(\mathrm{CH}_{4}\right)$. Despite the occurrence of successive steps, hydrolysis is generally considered as rate-limiting. Within the anaerobic environment, various important parameters affect the rates of the different steps of the digestion process, i.e. $\mathrm{pH}$ and alkalinity, temperature, and retention times. These parameters are assessed in Section 2 of the paper, together with the various types of anaerobic digesters used. The design is commonly based upon a population basis, using a volumetric solids loading or solids retention time, or on the basis of a required volatile solids reduction. Empirical design data are included. The methane generation rate can be estimated from kinetic equations.

An appropriate tank design (size, shape, covering), mixing and heating are needed to optimise the operation.

The optimisation of the $\mathrm{AD}$ and the assessment of its operation in function of varying feed or operating conditions are important objectives and can be pursued by using appropriate digestion models, reviewed in Section 3. These models are generally of the steady-state type and allow (i) to estimate retention time, reactor volume, gas production and composition for a requested system performance, (ii) to investigate the sensitivity of the system performance to various parameters, (iii) to provide cross-checking of simulation results and plant performance, and (iv) to determine how the digestion process can affect the design of upstream or downstream WWTP operations.

The number of models presented in literature is extensive, and often of very specific nature. The most frequently used model, ADM1, developed by the IWA forms a good basis and is often used in expanded models, as proposed by, e.g. Sötemann et al.

The previously mentioned models, and their validation, stress the importance of monitoring essential parameters during diges- tion. These essential parameters include $\mathrm{pH}$, alkalinity, VFA and biogas flow rate and composition. Again literature data are extensive and the quoted references illustrate the trend used in the monitoring and controling digestion plants.

Inhibiting compounds are either already present in the digester substrate or are generated during digestion. Section 4 reviewed the most commonly encountered inhibitors including ammonia, sulphide, sodium and potassium, heavy metals, hydrogen, VFA and LCFA.

Limiting factors in AD are generally associated with the hydrolysis stage. During hydrolysis, cell walls are ruptured and extracellular polymeric substances (EPS) are degraded resulting in the release of readily available organic material for the acidogenic micro-organisms. Various sludge disintegration methods have been studied as a pre-treatment and are discussed in Section 5 . These methods include mechanical, thermal, chemical and biological action, as reviewed with their working mechanism and potential.

Biogas enrichment, compression and storage was dealt with in Section 6, which also deals with one of the emerging problems related to the energetic valorisation of the biogas, i.e. the presence of siloxanes. Only volatile siloxanes are posing a problem. All the currently used treatment techniques are end of pipe and remove siloxanes from the biogas. The most frequently used method for removing siloxanes is the adsorption on activated carbon.

As produced by digestion, biogas is a clean and environmentally friendly fuel, although it contains only about $55-65 \%$ of $\mathrm{CH}_{4}$. Other constituents include $30-40 \%$ of $\mathrm{CO}_{2}$, fractions of water vapour, traces of $\mathrm{H}_{2} \mathrm{~S}$ and $\mathrm{H}_{2}$, and possibly other contaminants (e.g. siloxanes).

Without further treatment, it can only be used at the place of production. There is a great need to increase the energy content of the biogas, thus making it transportable over larger distances. Ultimately, compression and use of gas cylinders or introduction into the gas network are targets. This enrichment and enhanced potential of use can only be achieved after removing the $\mathrm{CO}_{2}$ and contaminants. The basic ways of biogas utilisation in the production of heat and steam, the electricity generation/cogeneration, and as vehicle fuel were included in the discussion, each with required upgrading needs and applicable techniques.

The routine operation of digesters needs adequate maintenance and repairs, cleaning and start-up/shutdown procedures. A very detailed account for operations, troubleshooting and control has been previously published. Section 7 referred the reader to these extensive summaries.

\section{References}

[1] Baeyens J, Hosten L, Van Vaerenbergh E. Afvalwaterzuivering (Wastewater treatment). 2nd ed. The Netherlands: Kluwer Academic Publishers; 1997 [in Dutch].

[2] European Commission. Council Directive 86/278/EEC on the protection of the environment, and in particular soil, when sewage sludge is used in agriculture; 12 June 1986

[3] Werther J, Ogada T. Sewage sludge combustion. Prog Energ Combust 1999; 25:55-116.

[4] Dewil R, Baeyens J, Appels L. Enhancing the use of waste activated sludge as bio-fuel through selectively reducing its heavy metal content. J Hazard Mater 2007;144:703-7.

[5] Van de Velden M, Dewil R, Baeyens J, Josson L, Lanssens P. The distribution of heavy metals during fluidized bed combustion of sludge (FBSC). J Hazard Mater 2008;151:96-102.

[6] Metcalf \& Eddy. Wastewater engineering: treatment and reuse. 4th ed. New York: McGraw-Hill; 2003.

[7] Qasim SR. Wastewater Treatment Plants: Planning. Design and operation. 2nd ed. Boca Raton: CRC Press; 1999.

[8] Gerardi MH. The microbiology of anaerobic digesters. 1st ed. Somerset NJ: Wiley; 2003.

[9] Deublein D, Steinhauser A. Biogas from waste and renewable resources. 1st ed. Weinheim: Wiley-VCH; 2008. 
[10] Reynolds TD, Richards P. Unit operations and processes in environmental engineering. 2nd ed. Boston: PWS Publishing Co; 1995.

[11] IWA Task Group for Mathematical Modelling of Anaerobic Digestion Processes. Anaerobic Digestion Model No.1. London: IWA Publishing; 2002.

[12] Ghyoot W, Verstraete W. Anaerobic digestion of primary sludge from chemical pre-precipitation. Water Sci Technol 1997;6-7:357-65.

[13] Wang Q, Kuninobu M, Kamimoto K, Ogawa HI, Kato Y. Upgrading of anaerobic digestion of waste activated sludge by ultrasonic pre-treatment. Bioresource Technol 1999;68:309-13.

[14] Tiehm A, Nickel K, Zellhorn M, Neis U. Ultrasonic waste activated sludge disintegration for improving anaerobic stabilization. Water Res 2001; 35:2003-9.

[15] Vavilin VA, Rytov SV, Lokshina LY, Pavlostathis SG, Barlaz MA. Distributed model of solid waste digestion - effects of leachate recirculation and $\mathrm{pH}$ adjustment. Biotechnol Bioeng 2002;81:66-73.

[16] Aquino SF, Stuckey DC. Integrated model of the production of soluble microbial products (SMP) and extracellular polymeric substances (EPS) in anaerobic chemostats during transient conditions. Biochem Eng J 2008; 38:138-46.

[17] Boe K. Online monitoring and control of the biogas process. Ph.D. Thesis, Institute of Environment \& Resources, Technical University of Denmark, 2006.

[18] Turovskiy IS, Mathai PK. Wastewater sludge processing. New York: Wiley; 2006.

[19] Hwang MH, Jang NJ, Hyum SH, Kim IS. Anaerobic bio-hydrogen production from ethanol fementation: the role of $\mathrm{pH}$. J Biotechnol 2004;111:297-309.

[20] Stichting Toegepast Onderzoek Reiniging Afvalwater (STORA). Optimalisatie van de gistingsgasproductie, 1985 [in Dutch].

[21] Rehm HJ, Reed G, Pühler A, Stadler PJW. Biotechnology, vol. 11A: Environmental processes I, 2nd ed. New York: Wiley, 2000.

[22] Igoni AH, Ayotamuno MJ, Eze CL, Ogaji SOT, Probert SD. Designs of anaerobic digesters for producing biogas from municipal solid-waste. Appl Energy 2008;85:430-8.

[23] Lue-Hing C. Municipal sewage sludge management: a reference text on processing, utilization and disposal, vol. IV, 2nd ed. Boca Raton, FL, USA: CRC Press, 1998 .

[24] Kessler DP, Greenkorn RA. Momentum, heat, and mass transfer fundamentals. Boca Raton, FL: CRC Press; 1999.

[25] Nopharatana A, Pullammanappallil PC, Clarke WP. A dynamic mathematical model for sequential leach bed anaerobic digestion of organic fraction of municipal solid waste. Biochem Eng J 2003;13:21-33.

[26] Barampouti EMP, Mai ST, Vlyssides AG. Dynamic modeling of the ratio volatile fatty acids/bicarbonate alkalinity in a UASB reactor for potato processing wastewater treatment. Environ Monit Assess 2005;110: 121-8.

[27] Alatiqi IM, Dadkhah AA, Akbar AM, Hamouda MF. Comparison between dynamics and control performance of mesophilic and thermophilic anaerobic sludge digesters. Chem Eng J Bioch Eng 1994;55:B55-66.

[28] Sötemann SW, Ristow NE, Wentzel MC, Ekama GA. A steady state model for anaerobic digestion of sewage sludges. Water SA 2005;31:511-28.

[29] Sötemann SW, Van Rensburg P, Ristow NE, Wentzel MC, Loewenthal RE, Ekama GA. Integrated chemical/physical and biological processes modelling, Part 2-Anaerobic digestion of sewage sludges. Water SA 2005;31:545-68.

[30] Bala BK. System dynamics modelling and simulation of biogas production systems. Renew Energy 1991;1:723-8.

[31] Siegrist H, Renggli D, Gujer W. Mathematical-modeling of anaerobic mesophilic sewage-sludge treatment. Water Sci Technol 1993;27:25-36.

[32] Lyberatos G, Skiadas IG. Modelling of anaerobic digestion-a review. Global Nest: Int J 1999;1:63-76.

[33] Andrews JF. Dynamic model of the anaerobic digestion model. J Sanit Eng Div Proc Am Soc Civ Engrs 1969;1:95-116.

[34] O'Rourke JT. Kinetics of anaerobic treatment at reduced temperatures. PhD Thesis, Stanford University, California, 1968.

[35] Eastman JA, Ferguson JF. Solubilization of particulate organic carbon during the acid phase of anaerobic digestion. J WPCF 1981;53:352-66.

[36] Pavlostathis SG, Gossett JM. A kinetic model for anaerobic digestion of biological sludge. Biotechnol Bioeng 2004;28:1519-30.

[37] Hidenari Y, Shigeki F, Kazuya K, Hideaki I, Akiyoshi O, Hideki H. Respirometric identification of hydrolysis kinetics for the modelling of anaerobic municipal sludge digestion process. Proc Environ Eng Res 2003; 40:291-300.

[38] Aceves-Lara CA, Aguilar-Garnica E, Alcaraz-Gonzales V, Gonzales-Reynoso O, Steyer JP, Gonzales-Alvaraz V. Kinetic and yield parameters estimation in an anaerobic digestion process using successive quadratic programming (SQ). In: Proceeding of 10th IWA world congress on Anaerobic Digestion (AD10), Montreal, Canada, vol. 3, 2004. p. 1329-34.

[39] Viotti P, Di Genova P, Falcioli F. Numerical analysis of the anaerobic codigestion of the organic fraction from municipal solid waste and wastewater: prediction of the possible performances at olmeto plant in Perugia (Italy). Waste Manage Res 2004;22:115-28.

[40] Lie E, Whelander T. A method for determination of the readily fermentable organic fraction in municipal wastewater. Water Res 1997;31:1269-74.

[41] Chachuat B, Bernard O, Steyer JP. Modelling anaerobic digestion for control purpose: which model complexity and which parameter accuracy. In; Proceedings of 10th IWA world congress on Anaerobic Digestion (AD10), Montreal, Canada, vol. 3, 2004. p. 1308-11.
[42] Bernard O. Obstacles and challenges for modelling biological wastewater treatment processes. In: Proceedings of the conference Automatique et Agronomie, Montpellier, France, 22-24 January 2003.

[43] Borja R, Rincon B, Raposo F, Alba J, Martin A. Kinetics of mesophilic anaerobic digestion of the two-phase olive mill solid waste. Biochem Eng J 2003:15:139-45.

[44] Jiménez AM, Borja R, Martin A. A comparative kinetic evaluation of the anaerobic digestion of untreated molasses and molasses previously fermented with Penicillium decumbens in batch reactors. Biochem Eng J 2004; $18: 121-32$

[45] Schoefs O, Dochain D, Fibrianto H, Steyer JP. Modelling and identification of a distributed-parameter model for an anaerobic wastewater treatment process. In: IEEE multiconference on computational engineering in systems applications, Lille, France, 9-11 July 2003.

[46] Saravanan V, Sreekrishman TR. Modelling anaerobic biofilm reactors-a review. J Environ Manage 2006;81:1-18.

[47] Cresson R, Carrère H, Delgenès JP, Bernet N. Biofilm formation during the start-up period of an anaerobic biofilm reactor-impact of nutrient complementation. Biochem Eng J 2006;30:55-62.

[48] Fuentes M, Scenna NJ, Aguirre PA, Mussati MC. Application of two anaerobic digestion models to biofilm systems. Biochem Eng J 2008;38:259-69.

[49] Graef SP, Andrews JF. Stability and control of anaerobic digestion. J WPCF 1974;46:667-82.

[50] Kleinstruer C, Powegha T. Dynamic simulator for anaerobic digestion process. Biotechnol Bioeng 1982;24:1941-51.

[51] Moletta R, Verrier D, Albagnac G. Dynamic modelling of anaerobic digestion. Water Res 1986;20:427-34.

[52] Smith PH, Bordeaux FM, Goto M, Shiralipour A, Wilke A, Andrews JF, et al Biological production of methane from biomass. In: Smith WH, Frank JR editors. Methane from biomass. A treatment approach. London: Elsevier; 1988. p. 291-334.

[53] Bryers JD. Structured modelling of the anaerobic digestion of biomass particulates. Biotechnol Bioeng 1985;27:638-49.

[54] Mosey FE. Mathematical modelling of the anaerobic digestion process: regulatory mechanisms for the formation of short-chain volatile acids from glucose. Water Sci Technol 1983;15:209-32.

[55] Costello DJ, Greenfield PF, Lee PL. Dunamic modelling of a single-state highrate anaerobic reactor-I. Model derivation. Water Res 1991;25:847-58.

[56] Batstone DJ, Keller J, Angelidaki RI, Kalyuzhnyi SV, Pavlostathis SG, Rozzi A et al. Anaerobic digestion model no 1 (ADM1). Water Sci Technol 2002; 45:65-73.

[57] Kiely G, Tayfur G, Dolan C, Tanji K. Physical and mathematical modelling of anaerobic digestion of organic wastes. Water Res 1997;31:534-40.

[58] Lokshina LY, Vavilin VA. Kinetic analysis of the key stages of low temperature methanogenesis. Ecol Model 1999;117:285-303.

[59] Nopharatana A, Pullammanappallil PC, Clarke WP. Kinetics and dynamic modelling of batch anaerobic digestion of municipal solid waste in a stirred reactor. Waste Manage 2007;27:595-603.

[60] Pontes RFF, Pinto JM. Analysis of integrated kinetic and flow models for anaerobic digesters. Chem Eng J 2006;122:65-80.

[61] Siegrist H, Vogt D, Garcia-Heras JL, Gujer W. Mathematical model for mesoand thermophilic anaerobic sewage sludge digestion. Environ Sci Techno 2002;36:1113-23.

[62] IWA Task Group on Mathematical Modelling for Design and Operation of Biological Wastewater Treatment. Activated sludge models ASM1, ASM2, ASM2d and ASM3. London: IWA Publishing; 2000.

[63] Zaher U, Rodríguez J, Franco A, Vanrolleghem PA. Conceptual approach for ADM1 application. In: Selected Proceedings of the IWA international conference. Kuala Lumpur, Malaysia: Water and Environment Management Series (WEMS); 2004. p. 249-58.

[64] Zaher U, Rodríguez J, Franco A, Vanrolleghem PA. Application of the IWA ADM1 model to simulate anaerobic digester dynamics using a concise set of practical measurements. In: Proceedings IWA conference on environmental biotechnology. Kuala Lumpur, Malaysia: Advancement on Water and Wastewater Applications in the Tropics; 2003.

[65] Ruiz G, Rodríguez J, Roca E, Lema JM. Modification of the IWA-ADM1 for application to anaerobic treatment of ethanolic wastewater from wine factories. In: Proceedings of 10th IWA World Congress on Anaerobic Digestion (AD10), Montreal, Canada, vol. 3, 2004. p. 1341-4.

[66] Lardon L, Punal A, Steyer JP, Martinez JA. Modular expert system for the diagnosis of operating conditions of industrial anaerobic digestion plants. In: Proceedings of 10th IWA World Congress on Anaerobic Digestion 2004 (AD10), Montreal, Canada, vol. 1, 2004. p. 324-9.

[67] Zaher U, de Gracia M, Vanrolleghem PA. Implementation of anaerobic digestion models for plant wide modelling and performance benchmarking. In: Proceedings of the seventh Latin American workshop and symposium on Anaerobic Digestion, Merida, Mexico, October 22-25, 2002.

[68] Fezzani B, Cheikh RB. Implementation of IWA anaerobic digestion model No. 1 (ADM1) for simulating the thermophilic anaerobic co-digestion of olive mill wastewater with olive mill solid waste in a semi-continuous tubular digester. Chem Eng J 2007;132:195-203.

[69] Batstone DJ, Keller J, Steyer JP. A review of ADM1 extensions, applications, and analysis: 2002-2005. Water Sci Technol 2006;54:1-10.

[70] Blumensaat F, Keller J. Modelling of two-stage anaerobic digestion using the IWA anaerobic digestion model no. 1 (ADM1). Water Res 2005;39: 171-83. 
[71] Henze M, Gujer W, Mino T, Van Loosdrecht M. Activated Sludge Models ASM1, ASM2, ASM2D and ASM3. Scientific and Technical Report No. 9 London: IWA Publishing; 2000.

[72] Dold PL, Ekama GA, Marais GvR. A general model for the activate sludge process. Prog Water Technol 1980;12:47-77.

[73] Henze M, Grady CPL, Gujer W, Marais GvR, Matsuo T. Activated sludge model No. 1, IWA Scientific and Technical Report No. 1. London: IWA Publishings; 1987.

[74] Izzett HB, Wentzel MC, Ekama GA. The effect of thermophilic heat treatment on the anaerobic digestibility of primary sludge. Research Report, Department of Civil Engineering, University of Cape Town, South Africa, 1992

[75] Ekama GA, Sötemann SW, Wentzel MC. Biodegradability of activated sludge organics under anaerobic conditions. Water Res 2007;41:244-52.

[76] Ferrer J, Seco A, Serralta J, Ribes J, Manga J, Asensi E, et al. DESASS: a software tool for designing, simulating and optimising WWTPs. Environ Modell Software 2008;23:19-26.

[77] Bernard O, Dantec BL, Chahuat B, Steyer J-Ph, Lardon L, Lambert S, et al. Telemac: an integrated system to remote monitor and control anaerobic wastewater treatment plants through the internet. In: Proceedings of 10th IWA world congress on Anaerobic Digestion (AD10), Montreal, Canada, vol. 1 29 August-2 September 2004. p. 318-23.

[78] Mailleret L, Bernard O. A simple robust controller to stabilise an anaerobic digestion process. In: Proceedings of the computer applications in biotechnology-CAB8, 213-8, Quebec, 24-27 June 2001.

[79] Alatiqi IM, Dadkhan AA, Jabr NM. Dynamics and multivariable control analysis for anaerobic digestion. Chem Eng J 1990;43:B81-91.

[80] Alcaraz-González V, Harmand J, Dochain D, Rapaport A, Steyer JP, Pelayo Ortiz C, et al. A robust asymptotic observer for chemical and biochemical reactors. ROCOND, Milan, Italy, 25-27 June 2003.

[81] Bernard O, Chachuat B. Design and practical use of probabilistic observers for mass-balance based bioprocess models. In: Proceedings of the DYCOPS-7 conference, Cambridge, USA, 2004.

[82] Bernard O, Gouzé JL. Multi-observateurs en boucle fermée pour des modèles biotechnologiques mal connus. In: Proceedings of the CIFA conference, CDROM, Douz, Tunisia, 2004.

[83] Chachuat B, Bernard O, Martinez JA. Design of probabilistic software sensors for anaerobic digestion montoring. In: Proceedings of 10th IWA world congress on Anaerobic Digestion (AD10), Montreal, Canada, vol. 3, 29 August-2 September 2004. p. 1312-5.

[84] De Pauw DJW, Zaher U, Vanrolleghem PA. Protocol and optimal experimental design to set up a monitoring and control system at an anaerobic digester. In: Proceedings of the 10th IWA world congress on Anaerobic Digestion (AD10), Montreal, Canada, vol. 3, 29 August-2 September 2004. p. 1319-24.

[85] Gómez X, Cuetos MJ, Garcia AI, Morán A. An evaluation of stability by thermogravimetric analysis of digestate obtained from different biowastes. Hazard Mater 2007;149:91-105.

[86] Liu J, Olsson G, Mattiasson B. On-line monitoring of a two-stage anaerobic digestion process using a BOD analyzer. J Biotechnol 2004;109:263-75.

[87] Steyer JP, Lardon L, Bernard O. Sensors networks and uncertainty management in anaerobic digestion processes. In: Plenary lecture at the second international IWA conference on automation in water quality monitoring-Automonet 2004, Vienna, Austria, 19-20 April 2004.

[88] Vanrolleghem PA, Lee DS. On-line monitoring equipment for wastewater treatment processes: state of the art. In: Proceedings international IWA conference on automation in water quality monitoring (AutMoNet2002), Vienna, Austria, 21-22 May 2002.

[89] Yamaguchi M, Hake J, Tanimoto Y. Enzyme-activity for monitoring the stability in a thermophilic anaerobic-digestion of wastewater containing methanol. J Ferment Bioeng 1991;71:264-9.

[90] Zaher U, Bouvier JC, Steyer J-Ph, Vanrolleghem PA. Titrimetric monitoring of anaerobic digestion: VFA, alkalinities and more. In: Proceedings of 10th IWA world congress on Anaerobic Digestion (AD10), Montreal, Canada, vol. 1. 2004. p. 330-6, 29 August-2 September 2004.

[91] Alcaraz-González V, Harmand J, Rapaport A, Steyer JP, González-Álvarez V, Pelayo-Ortiz C. Robust interval-based siso regulation in anaerobic digestion. In: Proceedings of 10th IWA world congress on Anaerobic Digestion (AD10), Montreal, Canada, vol. 1. 29 August-2 September 2004. p. 337-42.

[92] Hess J, Bernard O. Design and study of a risk management criterion for an unstable anaerobic wastewater treatment process. J Process Contr 2008; 18:71-9.

[93] Mailleret L, Bernard O, Steyer JP. Robust regulation of anaerobic digestion processes. In: IWA VII Latin American workshop and symposium on Anaerobic Digestion, Merida, Mexico, 22-25 October 2002. p. 10-111.

[94] Mailleret L, Bernard O, Steyer JP. Contrôle asymptotique non-linéaire des fermenteurs anaérobie. J Eur Systèmes Automat 2003;37:275-86.

[95] Mailleret L, Bernard O, Steyer JP. Robust nonlinear adaptive control for bioreactors with unknown kinetics. Automatica 2004;40:1379-85.

[96] Puñal A, Palazzotto L, Bouvier JC, Conte T, Steyer JP, Delgenes JP. Automatic control of VFA in anaerobic digestion using a fuzzy logic based approach. Water Sci Technol 2003;48:103-10.

[97] Puñal A, Palazotto L, Lardon L, Steyer JP. Compared Fuzzy Logic approaches for automatic control of $\mathrm{CH} 4$ flow-rate production and VFA effluent concentration in anerobic digestion. In: Proceedings of 10th IWA world congress on Anaerobic Digestion (AD10), Montreal, Canada, vol. 3, 29 August-2 September 2004. p. 1345-9.
[98] Ruiz G, Castellano M, González W, Roca E, Lema JM. Transient state detection and prediction of organic overload in anaerobic digestion process using statistical tools. In Proceedings of the ninth international symposium on computer applications in biotechnology (CAB9), Nancy-France, March 2004. p. 82

[99] Vanrolleghem PA, Rosen C, Zaher U, Copp J, Benedetti L, Ayesa E, et al. Continuity-based interfacing of models for wastewater systems described by Peterson matrices. In: Proceedings of 10th IWA world congress on Anaerobic Digestion (AD10), Montreal, Canada, vol. 1, 29 August-2 September 2004. p. 187-92.

[100] Chen Y, Cheng JJ, Creamer KS. Inhibition of anaerobic digestion process: a review. Bioresour Technol 2008;99:4044-64.

[101] Sung S, Liu T. Ammonia inhibition on thermophilic anaerobic digestion. Chemosphere 2003;53:43-52.

[102] Hansen KH, Angelidaki I, Ahring BK. Anaerobic digestion of swine manure: inhibition of ammonia. Water Res 1998;32:5-12.

[103] Liu T, Sung S. Ammonia inhibition on thermophilic aceticlastic methanogens. Water Sci Technol 2002;45:113-20.

[104] Dewil R, Baeyens J, Roelandt F, Peereman M. The analysis of the total sulphur content of wastewater treatment sludge by ICP-OES. Environ Eng Sci 2006; 23:904-7.

[105] Feijoo G, Mendéz R, Lema JM. Sodium inhibition in the anaerobic digestion process: antagonism and adaptation phenomena. Enzyme Microb Technol 1995; 17:180-8.

[106] Bashir BH, Matin A. Combined effect of potassium and magnesium on sodium toxicity in anaerobic treatment processes. EJEAFChe 2004;4:827-34.

[107] Liu Y, Boone DR. Effects of salinity on methanogenic decomposition. Bioresour Technol 1991;35:271-3.

[108] Bashir BH, Matin A. Effect of calcium and potassium on sodium inhibition to methanogenesis in anaerobic treatment processes. EJEAFChe 2004;3: 769-76.

[109] Kugelman IJ, McCarthy PL. Cation toxicity and stimulation in anaerobic waste treatment. J Water Pollut Control Fed 1964;37:97-116.

[110] Bashir BH, Matin A. Combined effect of calcium and sodium on potassium toxicity in anaerobic treatment processes. EJEAFChe 2004;3:670-6.

[111] Bashir BH, Matin A. Reduction of potassium toxicity by using sodium in a completely mixed anaerobic digester. EJEAFChe 2005;4:851-7.

[112] Jackson-Moss CA, Duncan JR. The effect of calcium on anaerobic digestion. Biotechnol Lett 1989;11:219-24

[113] Juliastuti SR, Baeyens J, Creemers C, Bixio D, Lodewyckx E. The inhibitory effects of heavy metals and organic compounds on the net maximum specific growth rate of the autotrophic biomass in activated sludge. J Hazard Mater 2003;100:271-83.

[114] Dewil R, Baeyens J, Neyens E. Reducing the heavy metal content of sewage sludge by advanced sludge treatment methods. Env Eng Sci 2006;23:994-9.

[115] Ahring BK, Westermann P. Sensitivity of thermophilic methanogenic bacteria to heavy metals. Curr Microbiol 1985;12:273-6.

[116] Beauchesne I, Cheikh RB, Mercier G, Blais J-F, Ouarda T. Chemical treatment of sludge: in-depth study on toxic metal removal efficiency, dewatering ability and fertilizing property preservation. Wat Res 2007;41:2028-38.

[117] Hayes TD, Teis TL. The distribution of heavy metals in anaerobic digestion. J Water Pollut Con F 1978;50:61-9.

[118] Lester JN, Sterritt RM, Kirk PWW. Significance and behaviour of heavy metals in wastewater treatment processes. II sludge treatment and disposal. Sci Total Environ 1983;30:45-83.

[119] Mosey FE, Hughes DA. The toxicity of heavy metal ions to anaerobic digestion. Water Pollut Control 1975;74:18-39.

[120] Vallee BL, Ulmer DD. Biochemical effects of mercury, cadmium and lead. Annu Rev Biochem 1972;41:91-128.

[121] Li CL, Fang HHP. Inhibition of heavy metals on fermentative hydrogen production by granular sludge. Chemosphere 2007;67:668-73.

[122] Massé DI, Droste RL. Comprehensive model of anaerobic digestion of swine manure slurry in an sequencing batch reactor. Water Res 2000;34: 3087-106.

[123] Mechichi T, Sayadi S. Evaluating process imbalance of anaerobic digestion of olive mill wastewaters. Process Biochem 2005;40:139-45.

[124] Batstone DJ, Keller J, Newell RB, Newland M. Modelling anaerobic degradation of complex wastewater. I: model development. Bioresour Technol 2000;75:67-74.

[125] Siegert I, Banks C. The effect of volatile fatty acid additions on the anaerobic digestion of cellulose and glucose in batch reactors. Process Biochem 2005;40:3412-8.

[126] Alves MM, Mota Viera JM, Pereira Alvares RM, Pereira MA, Mota M. Effects of lipids and oleic acid on biomass development in anaerobic fixed-bed reactors. Part II: oleic acid toxicity and biodegradability. Water Res 2001; 35:264-70.

[127] Angelidaki I, Ahring BK. Effects of free long-chain fatty acids on thermophilic anaerobic digestion. Appl Microbiol Biot 1992;37:808-12.

[128] Hwu CS, Tseng SK, Yuan CY, Kulik Z, Lettinga G. Biosorption of long-chain fatty acids in UASB treatment process. Water Res 1998;32:1571-9.

[129] Hwu CS, Donlon B, Lettinga G. Comparative toxicity of long-chain fatty acid to anaerobic sludges from various origins. Water Sci Technol 1996;34:351-8.

[130] Weemaes MPJ, Verstraete W. Evaluation of current wet sludge disintegration techniques. J Chem Technol Biotechnol 1998;73:83-92.

[131] Brooks R. Heat treatment of sewage sludge. Water Pollut Control 1970;69: 221-31. 
[132] Barlindhaug J, Ødegaard $H$. Thermal hydrolysate as a carbon source for denitrification. Water Sci Technol 1996;33:99-108.

[133] Hiraoka M, Takeda N, Sakai S, Yasuda A. Highly efficient anaerobic digestion with thermal pre-treatment. Water Sci Technol 1989;17:54.

[134] Pinnekamp J. Effects of thermal pre-treatment of sewage sludge on anaerobic digestion. Water Sci Technol 1989;21:97-108.

[135] Li YY, Noike T. Upgrading of anaerobic digestion of waste activated sludge by thermal pre-treatment. Water Sci Technol 1992;3-4:857-66.

[136] Tanaka S, Kobayashi T, Kamiyama K, Bildan MLS. Effects of thermochemical pre-treatment on the anaerobic digestion of wate activated sludge. Water Sci Technol 1997;8:209-15.

[137] Zheng J, Graff RA, Fillos J, Rinard I. Incorporation of rapid thermal conditioning into a wastewater treatment plant. Fuel Process Technol 1998; 56:183-200.

[138] Kim J, Park C, Kim T, Lee M, Kim S, Kim S, et al. Effects of various pretreatments for enhanced anaerobic digestion with waste activated sludge. J Biosci Bioeng 2003;95:271-5

[139] Valo A, Carrére H, Delgené J. Thermal, chemical and thermo-chemical pretreatment of waste activated sludge for anaerobic digestion. J Chem Technol Biotechnol 2004;79:1197-203.

[140] Ferrer I, Climent M, Baeza MM, Artola A, Vazquez F, Font X. Effect of sludge pretreatment on thermophilic anaerobic digestion. In: Proceedings of the IWA specialised conference on sustainable sludge management: state-of-the-art, challenges and perspectives, Moscow, Russia, May 29-31, 2006

[141] Climent M, Ferrer I, Baeza MD, Artola A, Vazquez F, Font X. Effects of thermal and mechanical pretreatments of secondary sludge on biogas production under thermophilic conditions. Chem Eng J 2007;133:335-42.

[142] Bougrier C, Degenes JP, Carrére H. Impacts of thermal pre-treatments on the semi-continuous anaerobic digestion of waste activated sludge. Biochem Eng J 2007;34:20-7.

[143] Gavala H, Yenal U, Skiadas I, Westermann P, Ahring B. Mesophilic and thermophilic anaerobic digestion of primary and secondary sludge. Effect of pre-treatment at elevated temperature. Water Res 2003;37:4561-72.

[144] Anonymous. Sludge treatment and disposal: thermal test. Water Qual Int 1996;Jul/Aug:24-5.

[145] Harrison STL. Bacterial cell disruption: a key unit operation in the recovery of intracellular products. Biotechnol Adv 1991;9:217-40.

[146] Kunz P, Mandel S, Theunert B, Wagner S. Disintegration von Klärschlamm. Tagungsland der 8. Krlsruher Flochungsstage, Universität Karlsruher Flochungstage, Universität Karlsruhe, 1994. p. 139-69.

[147] Dichtl N, Müller J, Braunschweig EE, Günthert FW, Osswald MO. Disintegration von Klärschlamm-ein aktueller Uberblick. Korrespondenz Abwasser 1997;44:1726-39.

[148] Rivard CJ, Nagle NJ. Pre-treatment technology for the beneficial reuse of municipal sewage sludges. Appl Bioch Biotechnol 1996;57-58:983-91.

[149] Choi HB, Hwang KY, Shin EB. Effects on anaerobic digestion of waste activated sludge pre-treatment. Water Sci Technol 1997;35:207-11.

[150] Baier U, Schmidheiny P. Enhances anaerobic degradation of mechanically disintegrated sludge. Water Sci Technol 1997;37:137-43.

[151] Kopp J, Muller J, Dichtl N, Schwedes J. Anaerobic digestion and dewatering characteristics of mechanically disintegrated excess sludge. Water Sci Technol 1997;36:129-36.

[152] Nah IW, Kang YW, Hwang KY, Song WK. Mechanical pre-treatment of waste activated sludge for anaerobic digestion process. Water Res 2000;34: 2362-8.

[153] Neyens E, Baeyens J. A review of thermal sludge pre-treatment processes to improve dewaterability. J Hazard Mater 2003:98:51-67.

[154] Knezevic Z, Mavinic DS, Anderson BC. Pilot scale evaluation of anaerobic codigestion of primary and pretreated waste activated sludge. Water Environ Res 1995;67:835-41.

[155] Tanaka S, Kobayashi T, Kamiyama K, Signey Bildan ML. Effects of thermochemical pre-treatment on the anaerobic digestion of waste activated sludge. Water Sci Technol 1997;35:209-15.

[156] Inagaki N, Suzuki S, Takemura K, Miyata A. Enhancement of anaerobic sludge digestion by thermal alkaline pre-treatment. In: Proceedings of the eighth international conference on Anaerobic Digestion, Sendai, Japan, May 25-29, 1997.

[157] Tanaka S, Kamiyama K. Thermochemical pre-treatment in the anaerobic digestion of waste activated sludge. Water Sci Technol 2002;46:173-9.

[158] Carballa M, Omil F, Lema JM. Improvement of anaerobic digestion operation and digested sludge characteristics using chemical and thermal pretreatment. In: 10th world congress of Anaerobic Digestion, Montreal, Canada, 23 August-2 September, 2004.

[159] Zimpro Environmental, Inc. Rotschild, wis., wet air oxidation cleans up black wastewater. Chem Eng 1993;September:175-6.

[160] Rinzema. Natte oxidatie van zuiveringsslib met het Vertech system. Stora/ Rijkswaterstaat, RWZI 2000, 1992.

[161] Ødeby T, Netteland T, Solheim OE. Thermal hydrolysis as a profitable way of handling sludge. In: Hahn $\mathrm{H}$, et al., editors. Chemical water and wastewater treatment IV. Berlin: Springer; 2002.

[162] Weemaes M, Grootaerd H, Simoens F, Verstraete W. Anaerobic digestion of ozonized biosolids. Water Res 2000;34:2330-6.

[163] Battimelli A, Millet C, Delgenes JP, Moletta R. Anaerobic digestion of waste activated sludge combined with ozone post-treatment and recycling. Water Sci Technol 2003;48:61-8.
[164] Goel R, Tokutomi T, Yasui H. Anaerobic digestion of excess activated sludge with ozone pre-treatment. Water Sci Technol 2003;47:207-14.

[165] Neyens E, Baeyens J. A review of classic Fenton's peroxidation as an advanced oxidation technique. J Hazard Mater 2003;98:33-50.

[166] Neyens E, Baeyens J, Weemaes M, De heyder B. Advanced biosolids treatment using $\mathrm{H}_{2} \mathrm{O}_{2}$-oxidation. Environ Eng Sci 2002;19:27-35.

[167] Neyens E, Baeyens J, Weemaes M, De heyder B. Pilot-scale peroxidation $\left(\mathrm{H}_{2} \mathrm{O}_{2}\right)$ of sewage sludge. J Hazard Mater 2003;98:91-106.

[168] Dewil R, Appels L, Baeyens J, Degrève J. Peroxidation enhances the biogas production in the anaerobic digestion of biosolids. J Hazard Mater 2007; 146:577-81.

[169] Dewil R, Baeyens J, Goutvrind R. Ultrasonic treatment of waste activated sludge. Environ Progr 2006;25:121-8.

[170] Shimizu T, Kudo K, Nasu Y. Anaerobic waste-activated sludge digestion-a bioconversion mechanism and kinetic model. Biotechnol Bioeng 1993; 41:1082-91.

[171] Neis U, Tiehm A, Nickel K. Enhancement of anaerobic sludge digestion by ultrasonic disintegration. Water Sci Technol 2000;42:73-80.

[172] Appels L, Dewil R, Baeyens J. Ultrasonically enhanced anaerobic digestion of waste activated sludge. Int J Sustain Eng 2008; in press, doi:10.1080/ 19397030802243319

[173] Miah M, Tada C, Sawayama S. Enhancement of biogas production from sewage sludge with the addition of Geobacillus sp. strain AT1 culture. Jpn J Water Treatment 2004;40(3):97-104.

[174] Guellil A, Boualam M, Quiquampoix H, Ginestet P, Audic JM, Block JC. Hydrolysis of wastewater colloidal organic matter by extracellular enzymes extracted from activated sludge flocs. Water Sci Technol 2001;43:33-40.

[175] Thomas L, Jungschaffer G, Sprossler B. Improved sludge dewatering by enzymatic treatment. Water Sci Technol 1993;28:189-92.

[176] Persson M, Johnsson O, Wellinger A. IEA Bioenergy Report-Task 37, December 2006; at 〈http://www.novaenergy.ih/iea-bioenergy-task37/documente/biogas.pdf $>$ [assessed on 10th January 2008].

[177] SenterNovem. Biogas as vehicle fuel, a trend setter report; at <http:// www.novem.nl $>$ [assessed on 10th January 2008].

[178] Van de Velden M, Baeyens J, Boukis I. Modelling CFB biomass pyrolysis reactors, Biomass Bioeng 2008;32:128-39.

[179] Degrève J, Everaert K, Baeyens J. The use of gas membranes for VOC-air separations. Filtr Sep 2001;38:49-54.

[180] Wise DL. Fuel gas from biomass, vol. 2. Boca Raton, FL: CRC Press; 1981.

[181] Schomaker IT, Boerboom AHHM, Vissel A, Pfeifer AE. Technical summary of gas treatment. Anaerobic digestion of agro-industrial wastes. Information Network Project FAIR-CT96-2083, 2000.

[182] Pande DR, Fabian C. Feasability studies on the use of naturally occurring molecular sieve for methane enrichment from biogas. Gas Sep Purif 1989;3:143-7.

[183] Rautenbach R, Dahm W. Oxygen and methane enrichment-a comparison of module arrangements in gas permeation. Chem Eng Technol 1987;10: 256-61.

[184] Harasimowicz M, Orluk P, Zakrzewska-Trznadel G, Chmielewski AG. Application of polyimide membranes for biogas purification and enrichment. J Hazard Mater 2007;144:698-702.

[185] Lastella G, Testa C, Cornacchia G, Notornicola M, Voltasio F, Sharma VK Anaerobic digestion of semi-solid organic waste: biogas production and its purification. Energy Convers Manage 2002;43:63-75.

[186] Stern SA, Krishnakumar B, Charati SG, Amato WS, Friedmann AA, Fuess DJ. Performance of a bench-scale membrane pilot plant for the upgrading of biogas in a wastewater treatment plant. J Membr Sci 1998;151:63-74.

[187] Li K, Teo WK. Use of an internally staged permeator in the enrichment of methane from biogas. J Membr Sci 1993;78:181-90.

[188] Toshima N. Polymers for gas separations. NY: VCH Publishers; 1992.

[189] Glub JC, Diaz LF. Biogas purification processes. Biogas and alcohol fuels production, vol. II. JP Press Inc.; 1991

[190] Dewil R, Baeyens J, Roels J, Van De Steene B. The distribution of sulphur compounds in sewage sludge treatment. Environ Eng Sci 2008;25:879-86.

[191] Hagen M, Polman E. Adding gas from biogas to the gas grid. Final Report Danish Gas Agency, 2001. p. 26-47.

[192] Kapdi SS, Vijay VK, Rakesh SK, Prasad R. Biogas scrubbing, compression and storage: perspective and prospectus in Indian context. Renewable Energy 2005; $30: 1195-202$.

[193] Dewil R, Appels L, Baeyens J. Energy use of biogas hampered by the presence of siloxanes. Energy Convers Manage 2006;47:1711-22.

[194] Schweigkofler M, Niessner R. Removal of siloxanes in biogases. J Hazard Mater 2001;83:183-96.

[195] Hagmann M, Heimbrand E, Hentschel P. Determination of siloxanes in biogas from landfills and sewage treatment plants. In: Proceedings Sardinia 99, seventh international waste management and landfill symposium, Cagliari, Italy, 4-8 October 1999.

[196] Griffin P. Severn Trent Water wastewater treatment plant at Minworth. In: ST-seminar, 2004.

[197] Dewil R, Appels L, Baeyens J, Buczynska A, Van Vaeck L. The analysis of volatile siloxanes in waste activated sludge. Talanta $2007 ; 74: 14-9$.

[198] UK Environment Agency. Guidance on gas treatment technologies for landfill gas engines, Bristol, UK, 2002.

[199] Huppmann R, Lohoff HW, Schröder HF. Cyclic siloxanes in the biological waste water treatment process-determination, quantification and possibilities of elimination. Fr J Anal Chem 1996;354:66-71. 
[200] Appels L, Baeyens J, Dewil R. Siloxane removal from biosolids by peroxidation. Energy Convers Manage 2008; in press, doi:10.1016/j.econman.2008.03.006.

[201] Biswas TD, Kartha ARS, Pundarikakhady R. Proceedings of the national symphony on biogas technology and uses. New Delhi: AIRI; 1977.

[202] Mande S. SESI Newsletter, vol. 333, 2000. p. 5
[203] Nema A, Bhuchner K. Bio-energy News 2002;6:10-2.

[204] Wellinger A, Lindeberg A. Biogas upgrading and utilisation, Task 24. Energy from Biological Conversion of Organic Wastes 1999:1-19.

[205] Wallis JL, Ross C, Smith MS, Harper SR. Biomass 1989;20:277-90.

[206] Zickefoose C, Hayes RBJ. Operations manual. EPA 430/9-76-001, Anaerobic Sludge Digestion US EPA, Washington, DC, 1976. 